\title{
CONCENTRAÇÃO DE NUTRIENTES NOS FRUTOS E FOLHAS E EXPORTAÇÃO DE NUTRIENTES PELA COLHEITA DURANTE UM CICLO PRODUTIVO DO CAFEEIRO (Quffea arabica L. CV. CATUAI)
}

\author{
JÚLIO CÉSAR DIAS CHAVES
}

Orientador: Dr. JOSÉ RENATO SARRUGE

Dissertação apresentada à Escola Superior de Agricultura "Luiz de Queiroz", da Universidade de São Paulo, para a obtenção do título de Mestre em Solos e Nutrição de Plantas.

\author{
PIRACICABA \\ Estado de São Paulo - Brasil \\ Maio - 1982
}




\begin{abstract}
Aos meus pais,
i rmãos

e amigos
\end{abstract}

DEDICO

A minha esposa Erica

e ao meu filho Henrique Augusto

OFEREÇO 


\section{AGRADECIMENTOS}

Ao Prof. Dr. Josē Renato Sarruge pela orientação e apoio irrestritos durante o desenvolvimento deste trabalho;

Ao Prof. Dr. Antonio Roque Dechen pela colaboração durante a fase de anālise quĩmica do material;

Ao Prof. Dr. Henrique Vianna de Amorin pela colaboração du rante a fase de preparo das amostras;

Ao Pesquisador Científico do IAPAR Dr. Marcos Antonio Pavan pela versão do resumo em inglēs;

Aos Engenheiros Agrōnomos Armando Androciolli Filho e Tumoru Sera pelo apoio durante o desenvolvimento do plano experimental;

A Bibliotecária Maria Elizabeth Ferreira de Carvalho pela revisão da bibliografia;

Aos Funcionāirios do Laboratōrio de Quĩmica da E.S.A. "Luiz de Queiroz", Francisco Carlos Antoniolli, Lūcia Helena S.Pavan e Lurdes Aparecida Dārio pela anālise quî̉mica do material;

A Fundação Instituto Agronōmico do Paranā - IAPAR pela oportunidade concedida para realização do curso;

A Empresa Brasileira de Pesquisas Agropecuārias - EMBRAPA pelo auxîlio financeiro;

A Escola Superior de Agricultura "Luiz de Queiroz" pela acolhida e oportunidade de aperfeiçoamento. 
INDICE

Pāgina

LISTA DE TABELAS $\ldots \ldots \ldots \ldots \ldots \ldots \ldots \ldots \ldots \ldots \ldots \ldots \ldots \ldots \ldots \ldots \ldots \ldots \ldots \ldots \ldots$

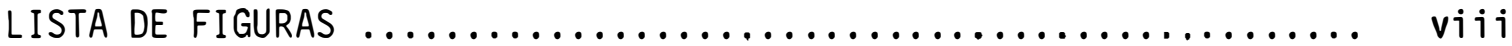

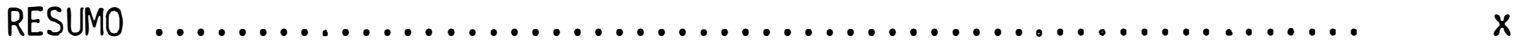

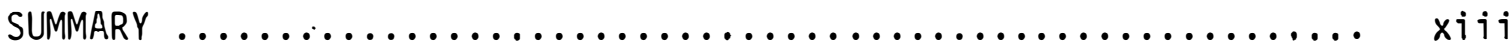

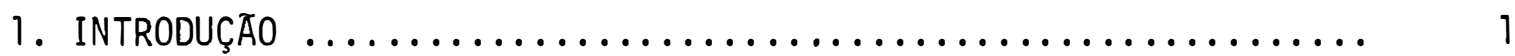

2. REVISÃO DE LiteRATURA $\ldots \ldots \ldots \ldots \ldots \ldots \ldots \ldots \ldots \ldots \ldots \ldots \ldots$

2.1. Absorção e redistribuição de nutrientes pelas plantas .................................. 4

2.1.1. Absorção de nutrientes ................... 4

2.1.2. Redistribuição de Nutrientes ............... 14

2.2. Composição Química ......................... 23

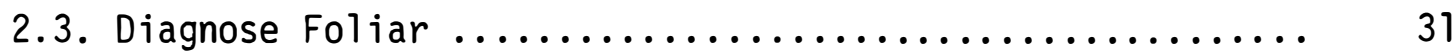

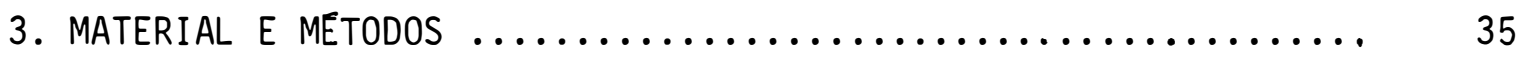

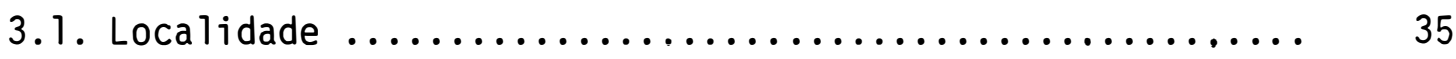

3.2. Coleta de Frutos e Folhas ...................... 40

3.3. Preparo e Anālise das Amostras .................... 41

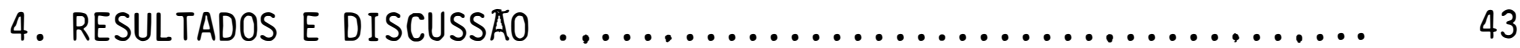

4.1. Desenvolvimento dos Frutos .................... 43

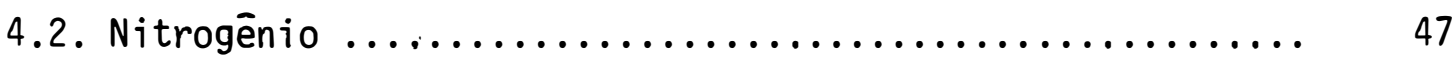

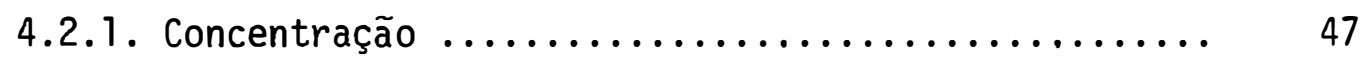

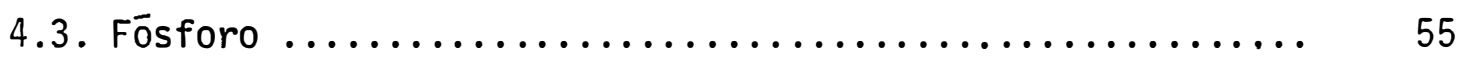

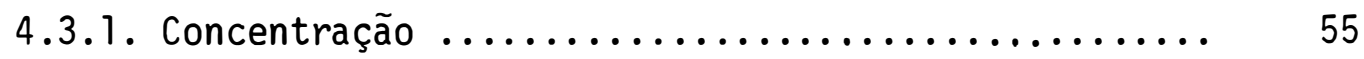


Pāgina

4.4. Potāssio .................................... 61

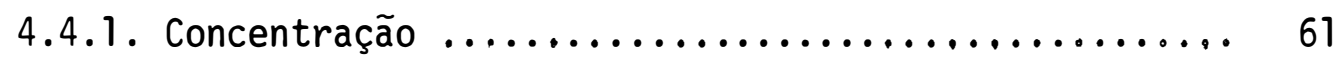

4.5. Cālcio ................................... 68

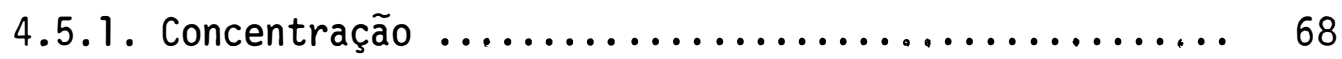

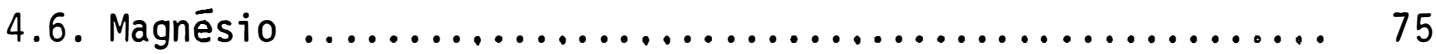

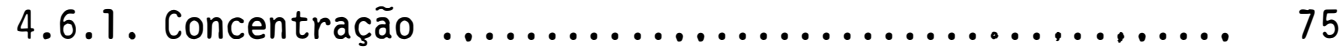

4.7. Enxofre $\ldots \ldots \ldots \ldots \ldots \ldots \ldots \ldots \ldots \ldots \ldots \ldots \ldots \ldots \ldots \ldots \ldots$

4.7.1. Concentração .............................. 81

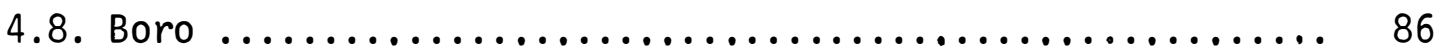

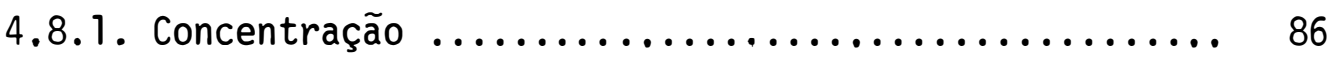

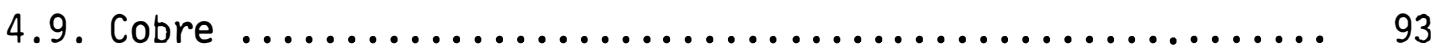

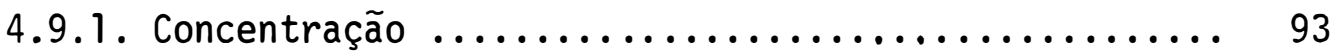

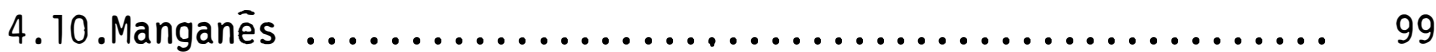

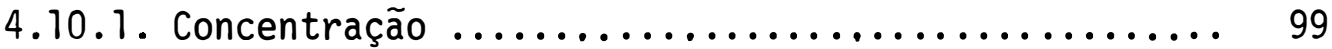

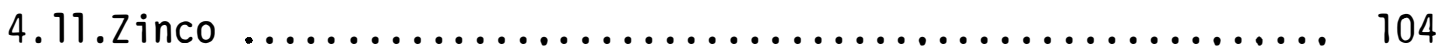

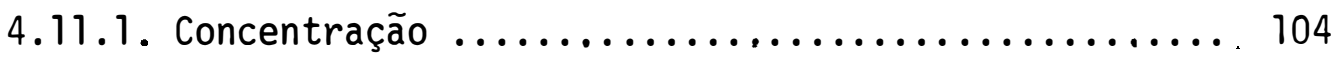

4.12. Extração dos Nutrientes ....................... 109

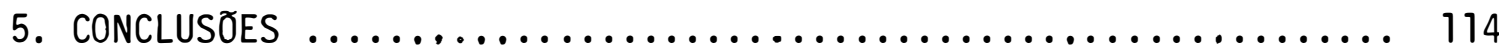

5.1. Desenvolvimento dos Frutos ................... 114

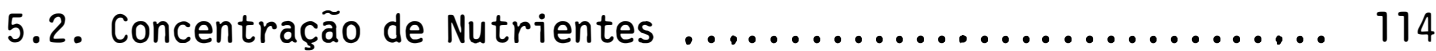

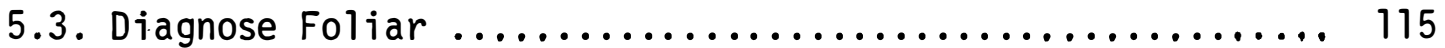

5.4. Redistribuição de Nutrientes ................... 115

5.5. Extração de Nutrientes $\ldots \ldots \ldots \ldots \ldots \ldots \ldots \ldots \ldots \ldots \ldots$

LITERATURA CITADA ........................... 117 
1 Anālise Granulométrica e Química para fins de

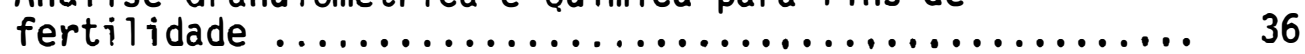

2 Adubação dos Cafeeiros ..................... 37

3 Dados termopluviométricos diārios do Centro Experimental do IAPAR - Londrina-PR, no período de

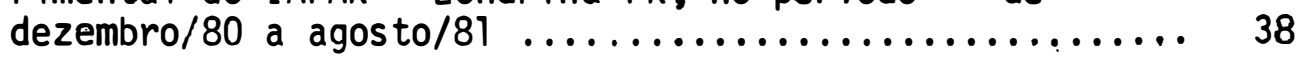

4 Epoca de amostragem de frutos e folhas ............ 41

5 Acúmulo de matéria seca pelos frutos de uma cova de cafeeiros ( 2 plantas), em função do seu desenvolvimento (média de 6 repetições) ................ 44

6 Anālises da variāncia do peso ( $g / c o v a)$ da matéria seca e teor de macronutrientes dos frutos do ca-

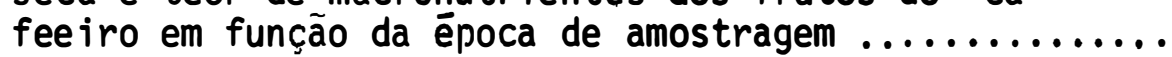

7 Concentração (\%) de nitrogênio dos frutos, das folhas de ramos com frutos e das folhas de ramos sem frutos, em função da époça de amostragem ......... 48

8 Anālise da variāncia do teor de macronutrientes das folhas de ramos com frutos e das folhas de ramos sem frutos, em função da época de amostra-

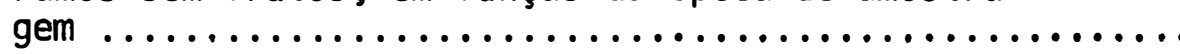

9 Concentração (\%) de fósforo dos frutos, das folhas de ramos com frutos e das folhas de ramos sem frutos, em função da época de amostragem ......... 56

10 Concentração (\%) de potássio dos frutos, das fothas de ramos com frutos e das folhas de ramos sem frutos, em função da época de amostragem ......... 62

11 Concentração (\%) de cālcio dos frutos, das foThas de ramos com frutos e das folhas de ramos sem frutos, em função da época de amostragem ...........

12 Concentração (\%) de magnēsio dos frutos, das foThas de ramos com frutos e das folhas de ramos sem frutos, em função da época de amostragem ..........

13 Concentração (\%) de enxofre dos frutos, das folhas de ramos com frutos e das folhas de ramos sem frutos, em função da época de amostragem .......... 
14 Concentração (ppm) de boro dos frutos, das foThas de ramos com frutos e das folhas de ramos sem frutos, em função da época de amostragem ..........

15 Anālise da variância do teor de micronutrientes dos frutos do cafeeiro, em função da época de amostragem

16 Anālise da variāncia do teor de micronutrientes das folhas de ramos com frutos e folhas de ramos sem frutos, em função da época de amostragem .......

17 Concentração ( $\mathrm{ppm}$ ) de cobre dos frutos, das foThas de ramos com frutos e das folhas de ramos sem frutos, em função da época de amostragem ..........

18 Concentração (ppm), de manganēs dos frutos, das folhas de ramos com frutos e das folhas de ramos sem frutos, em função da época de amostragem ...... 100

19 Concentração (ppm de zinco dos frutos, das foThas de ramos com frutos e das folhas de ramos sem frutos, em função da época de amostragem ..........

20 Quantidades (g/cova) de macronutrientes acumuladas e matéria seca produzida pelos frutos do cafeeiro nas épocas (dias entre parēnteses) de

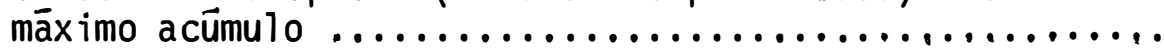

21 Quantidades ( $\mathrm{g} /$ cova) de macronutrientes acumula das pelos frutos do cafeeiro e percentagem (\%) do total absorvido durante seu desenvolvimento ....... 111

22 Quantidades_(mg/cova) de micronutrientes acumuladas e matéria seca produzida pelos frutos do cafeeiro nas épocas (dias entre parênteses) de

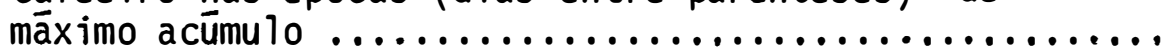

23 Quantidades ( $\mathrm{g} /$ cova) de micronutrientes acumula das pelos frutos do cafeeiro e percentagem $(\%)$ do total absorvido durante seu desenvolvimento 
vi i

\section{LISTA DE FIGURAS}

Figura nọ

Pāgina

$1 \quad$ Curva de Regressão da quantidade de matēria seca (y) acumulada pelo fruto do cafeeiro em função do seu desenvolvimento $(x) \ldots \ldots \ldots \ldots \ldots \ldots \ldots \ldots \ldots$

2 Curva de regressão do teor de nitrogênio $(y)$ no fruto do cafeeiro, em função do seu desenvolvimento(x) ....

3 Curvas de regressão dos teores de nitrogēnio (y) em folha de ramos com frutos e folha de ramos sem frutos em função da época de amostragem $(x) \ldots . . . \ldots . . . .52$

4 Curva de regressão do teor de fósforo (y) no fruto do cafeeiro em função do seu desenvolvimento $(x)$.......

5 Curvas de regressão dos teores de fósforo (y) em foTha de ramos com frutos e folha de ramos sem frutos, em função da época de amostragem $(x) \ldots \ldots \ldots \ldots . . \ldots . .$.

6 Curva de regressão do teor de potāssio (y) no fruto do cafeeiro, em função do seu desenvolvimento $(x) \ldots .$.

7 Curvas de regressão dos teores de potássio (y) em fo Tha de ramos com frutos e folha de ramos sem frutos em função da época de amostragem $(x) \ldots . . \ldots \ldots . . . .$.

8 Curva de regressão do teor de cālcio (y) no fruto do cafeeiro, em função do seu desenvolvimento $(x) \ldots . . . ., 70$

9 Curvas de regressão dos teores de cālcio (y) em foTha de ramos com frutos e folha de ramos sem frutos, em função da época de amostragem $(x) \ldots \ldots \ldots \ldots \ldots \ldots . . . .$.

10 Curva de regressão do teor de magnésio (y) no fruto do cafeeiro, em função do seu desenvolvimento $(x)$......

11 Curvas de regressão dos teores de magnēsio (y) em fo Tha de ramos com frutos e folha de ramos sem fruto $\vec{s}$, em função da época de amostragem $(x) \ldots \ldots \ldots \ldots \ldots \ldots . . . .$.

12 Curva de regressão do teor de enxofre (y) no fruto do cafeeiro, em função do seu desenvolvimento $(x)$......

13 Curvas de regressão dos teores de enxofre (y) em foTha de ramos com frutos e folha de ramos sem frutos, em função da época de amostragem $(x) \ldots \ldots \ldots \ldots \ldots . . . .$. 
Figura nọ

Pägina

14 Curva de regressão do teor de boro (y) no fruto do cafeeiro, em função do seu desenvolvimento $(x), \ldots . .$. ...

15 Curvas de regressão dos teores de boro (y) em folha de ramos com frutos e folha de ramos sem frutos, em função da época de amostragem $(x) \ldots . . \ldots \ldots \ldots . . . . .$.

16 Curva de regressão do teor de cobre (y) no fruto do cafeeiro, em função do seu desenvolvimento $(x) \ldots . . . . .96$

17 Curvas de regressão dos teores de cobre $(y)$ em foTha de ramos com frutos e folha de ramos sem frutos, em função da época de amostragem $(x) \ldots . . . . . . . .997$

18 Curva de regressão do teor de manganês $(y)$ no fruto do cafeeiro em função do seu desenvolvimento $(x)$....... 101

19 Curvas de regressão dos teores de manganēs (y) em folha de ramos com frutos e folha de ramos sem frutos, em função da época de amostragem $(x)$............. 103

20 Curva de regressão do teor de zinco (y) no fruto do cafeeiro em função do seu desenvolvimento $(x) \ldots \ldots . . .106$

21 Curvas de regressão dos teores de zinco (y) em foTha de ramos com frutos e folha de ramos sem frutos, em função da época de amostragem $(x) \ldots . . . . . . .108$ 
CONCENTRACAO DE NUTRIENTES NOS FRUTOS E FOLHAS E EXPORTAÇAO DE NUTRIENTES PELA COLHEITA DURANTE UM CICLO PRODUTIVO DO CAFEEIRO (Coffea arabica L. cV. Catuai)

Jūlio César Dias Chaves

Orientador: Dr. Josē Renato Sarruge

RESUMO

Trabalho realizado em talhão de cafeeiros (Coffea arabica L. Cv. Catuai) H $2077-2$ - 5 - 39 com 5 anos de idade, localizado no cen tro experimental do IAPAR em Londrina - PR $\left(23^{\circ} 23^{\prime}\right.$ de latitude sul e $51^{\circ} 111^{\prime}$ de longitude oeste e $566 \mathrm{~m}$ de altitude), situado em um Latossolo Roxo distrōfico, com os objetivos de (1) determinar a variação de nutrien tes nos frutos e folhas do cafeeiro desde o inīcio de formação atē a maturação dos frutos; (2) quantificar a extração de nutrientes pelos frutos; (3) conhecer o ritmo de sua extração.

As amostragens, em número de 12, foram iniciadas quando os fruțos se apresentavam no estadio "chumbinho" e repetidas a cada 21 dias atē a maturação. Foram coletados frutos, fol has de ramos com frutos e foThas de ramos sem frutos. No material coletado foram determinados os teo res de nitrogênio, fósforo, potāssio, cālcio, magnēsio, enxofre, boro, co bre, manganēs e zinco.

Foram obtidas curvas representativas das concentrações dos nutrientes nos frutos, nas folhas de ramos com frutos e nas folhas de ramos sem frutos, em função da época (idade)a partir dos dados calculadas 
atravēs de equações de regressão. Pelos pontos de māximo estimaram-se a produção de matéria seca e as quantidades de nutrientes extraĩdos pelos frutos.

Concluiu-se que:

- A produção māxima de matēria seca nos frutos ocorreu aos 217 dias, a partir do inĩcio do aparecimento de "chumbinho".

- As concentrações de $\mathrm{N}, \mathrm{P}, \mathrm{K}, \mathrm{Ca}, \mathrm{Mg}, \mathrm{B}, \mathrm{Cu}, \mathrm{Mn}$ e $\mathrm{Zn}$ foram mais elevadas, nos frutos, no inīcio de sua formação e as concentrações de $S$ foram mais elevadas na sua maturação.

- 0 comportamento do $\mathrm{N}, \mathrm{P}, \mathrm{B}$ e $\mathrm{Zn}$ ao longo do desenvolvimento dos frütos, foi individualmente, diferente quando se analisaram foThas de ramos com frutos e folhas de ramos sem frutos. Para o $\mathrm{K}, \mathrm{Ca}, \mathrm{Mg}$, $\mathrm{S}$, Cu e Mn o comportamento foi semelhante para ambos os tipos de folhas.

- Nas folhas de ramos com frutos as concentrações de $N$, $P, K$, Mn e $Z n$ foram mais altas no início do desenvolvimento dos frutos en quanto que os teores de $\mathrm{Ca}, \mathrm{Mg}, \mathrm{S}, \mathrm{B}$ e $\mathrm{Cu}$ foram mais baixos neste mesmo perīodo.

- Nas folhas de ramos sem frutos as concentrações de P, K e Mn foram mais altas no início de desenvolvimento dos frutos enquanto que os teores de $\mathrm{N}, \mathrm{Ca}, \mathrm{Mg}, \mathrm{S}$, Cu e $\mathrm{Zn}$ foram mais baixos neste mesmo período. A concentração de B permaneceu estavel durante todo o período de frutificação.

- A avaliação do estado nutricional do cafeeiro (diagnose folịar) para N, P, B e Zn deve ser feita utilizando-se as folhas de ramos 
com frutos. Para K, Ca, Mg, S, Cu e Mn, pode ser feita utilizando-se tan to fol has de ramos com frutos quanto folhas de ramos sem frutos.

- A extração de nutrientes pelos frutos obedeceu a seguinte ordem decrescente: potāssio, nitrogênio, cālcio, magnēsio, enxofre, fósforo, manganès, boro, cobre e zinco. 


\section{NUTRIENT CONCENTRATION IN FRUITS AND LEAVES AND HARVEST REMOVAL OF NUTRIENTS IN ONE PRODUCTIVE CYCLE OF THE COFFEE PLANT (Cofgea arabica $L, C V$, CATUAI)}

Jūlio César Dias Chaves

Adviser: Dr. Josē Renato Sarruge

\section{SUMMARY}

A field experiment was conducted during the 1980-1981 growing season with five year-old coffee trees (Coffea arabica, L. cv. Catuai H $2677-2=5-39$ ) to investigate; (1) the nutrient content variations in the leaves and fruits of coffee trees from the early period of fruit formation (pinhead) until the final stage of fruit ripening, (2) the total amount of nutrients extracted by coffee fruits, and (3) the nutrient extraction rhythm by coffee fruits. The experimental field was located at the IAPAR Experimental Station, Londrina, State of Paranā, Brazil $\left(23^{\circ} 23^{\prime}\right.$ south latitude, $51^{\circ} 11^{\prime}$ west Greenwich longitude, and at $566 \mathrm{~m}$ altitude) where the dystrophic "roxo" latosol (0xisol) is the dominant soil type.

To determine the change in leaf and fruit nutrient content with time, leaf and fruit samples were collected every 21 day-intervals starting when the coffee fruits were young (pinhead) up to their final stages of complete maturation. A total of twelve samples were collected during the coffee fruit growing season. All samples were divided into leaf and fruit samples from branches with coffee fruits and leaf samples 
from branches without coffee fruits. These plant materials were dried, weighed, ground and then analyzed for $\mathrm{N}, \mathrm{P}, \mathrm{K}, \mathrm{Ca}, \mathrm{Mg}, \mathrm{S}, \mathrm{B}, \mathrm{Cu}, \mathrm{Mn}$ and $\mathrm{Zn}$. Regression equations are presented relating the nutrient concentration; in fruits and leaves of branches with fruits, and in leaves of branches without fruits as a function of time of sampling (physiological fruit age). The maximum production of dry matter and nutrient extracted by coffee were estimated from the maximum peak period obtained on the curves represented by a regression equation.

This study allowed the following conclusions:

- The maximum accumulation of dry matter in coffee fruits was obtained at 217 days counted from the early fruit formation (pinhead).

- The concentrations of $\mathrm{N}, \mathrm{P}, \mathrm{K}, \mathrm{Ca}, \mathrm{Mg}, \mathrm{B}, \mathrm{Cu}, \mathrm{Mn}, \quad$ and $\mathrm{Zn}$ were higher in young fruits (pinhead), whereas the concentration of $S$ was higher in old fruits (complete maturation).

- A plot of nutrient concentration as a function of sampling time indicated that; (1) the concentrations of $N, P, B$, and $\mathrm{Zn}$ in leaves sampled of branches with fruits were differents than those sampled of branches without fruits, and (2) the concentrations of $\mathrm{K}, \mathrm{Ca}$, $\mathrm{Mg}, \mathrm{S}, \mathrm{Cu}$, and Mn were approximately equal in leaves sampled of both types of branches.

- The concentrations of $N, P, K, Z n$, and $M n$ in leaves of branches with fruits were higher during the early fruit development, whereas the concentrations of $\mathrm{Ca}, \mathrm{Mg}, \mathrm{S}, \mathrm{B}$, and $\mathrm{Cu}$ in leaves of the same type of branches were lower during the early fruit growth than during the final fruit maturation. 
- The concentrations of $P, K$, and $M n$ in leave of branches without fruits were higher during the early fruit development, whereas the concentrations of $\mathrm{N}, \mathrm{Ca}, \mathrm{Mg}, \mathrm{S}, \mathrm{Cu}$, and $\mathrm{Zn}$ in leaves of the same type of branche were lower during this fruit stage. The concentration of $B$ in leaves was approximately constant during the fruit growth period. - Analysis of coffee leaves for diagnostic nutrient status indicated that the leaves of branches with coffee fruits best reflected the varying $\mathrm{N}, \mathrm{P}, \mathrm{B}$ and $\mathrm{Zn}$. For diagnosing $\mathrm{K}, \mathrm{Ca}, \mathrm{Mg}, \mathrm{S}, \mathrm{Cu}$, and $\mathrm{Mn}$ status, the study has shown that the leaf samples can be taken either from branches with fruits or from branches without fruits.

- The order of nutrient extraction by coffee fruits was the following: $\mathrm{K}>\mathrm{N}>\mathrm{Ca}>\mathrm{Mg}>\mathrm{S}>\mathrm{P}>\mathrm{Mn}>\mathrm{B}>\mathrm{Cu}>\mathrm{Zn}$. 
1. INTRODUÇÃO

A cultura do café (Coffea arabica, L.), foi introduzida no Brasil em 1727 no Estado do Parā, expandindo-se até a Bahia, atingindo o Rio de Janeiro, Espírito Santo, Minas Gerais, São Paulo e Paranā. Atualmente os Estados mais importantes na produção do Rubiācea são: Minas Gerais, São Paulo, Paranā e Espírito Santo.

Embora venha sofrendo as influēncias climāticas (secas e principalmente geadas) ao longo dos anos, continua sendo a cultura mais importante em termos de geração de divisas para o Paīs, contribuindo com cerca de $15 \%$ da receita com as exportações, segundo o IBC.

O Brasil ocupa desde muitos anos, a liderança mundial na produção e na exportação de café, No entanto, essa liderança vem sendo mantida graças a extensa ārea cafeeira, que compensa a baixíssima produtividade atual alcançada nas lavouras brasileiras: cerca de $500 \mathrm{~kg}$ de ca fé beneficado por hectare.

Entre os fatores que tem contribuido para a baixa produtividade, podem ser citados como de fundamental importāncia, aqueles 
relacionados com a nutrição e adubação do cafeeiro. A alta exigência nu tricional da espécie, muito sensível a desequilíbrios nutricionais, alia do ao pouco estudo, nesta ārea, da cultivar "Catuaĩ", hoje compondo gran de proporção do parque cafeeiro dos principais Estados, tem de certa for ma colaborado para que o problema se agrave ainda mais. A nutrição vegetal é analisada na agricultura principalmente soboponto de vista de produção; no caso do cafeeiro, quanto à produção de frutos (café). Normalmente, a produção é retirada da ārea produtora, levando consigo considerāveis quantidades de macro e micronutrientes. Especialmente no caso do café, variedade "Mundo Novo", sabe-se que $1000 \mathrm{~kg}$ de frutos exportam cerca de aproximadamente $17,0 \mathrm{~kg}$ de nitrogênio $(\mathrm{N}) 1,3 \mathrm{~kg}$ de fósforo $(P), 26,0 \mathrm{~kg}$ de potāssio (K), 3,5 kg de cālcio (Ca), 1,5 kg de magnésio (Mg), $1,5 \mathrm{~kg}$ de enxōfre (S), 25,0 $\mathrm{g}$ de boro (B), 55,0 $\mathrm{g}$ de ferro (Fe), $25,0 \mathrm{~g}$ de manganês $(\mathrm{Mn}), 41,0 \mathrm{~g}$ de zinco $(\mathrm{Zn})$, segundo MALAVOLTA (1981).

Conhecer a extração de nutrientes pelos frutos das variedades cultivadas atualmente, no que concerne a quantidade e época, signi fica possuir importante informação para a formulação de uma adubação equilibrada do cafeeiro.

No entanto, este fornecimento de fertilizantes só estará assentado em bases científicas quando, alēm da extração, também se conhecer o ritmo com que esses nutrientes são carreados para os frutos.

Os objetivos do presente trabalho foram os de determinar a variação na concentração de macro e micronutrientes nos frutos e foThas (de ramos com frutos, e de ramos sem frutos) do cafeeiro, desde o 
perīodo de início de formação atē a maturação dos frutos, bem como quantificar a sua extração de nutrientes. 


\section{REVISAOO DE LITERATURA}

\subsection{Absorção e redistribuição de nutrientes pelas plantas.}

\subsubsection{Absorção de nutrientes}

A produção final de uma cultura ē o reflexo da interação entre alguns fatores que fundamentalmente estão ligados ao germoplasma e ao meio ambiente. A produção de determinada espécie traduz o potencial de cada um desses fatores e sua integração no indivĩduo.

A capacidade de absorção de nutrientes pelas plantas se situa como um dos fatores de maior importāncia para a exaltação de seu potencial produtivo.

Embora outras partes da planta, principalmente as folhas, possam absorver certa quantidade de elementos minerais quando colocados em contato com ela, nas plantas superiores o órgão sede por excelência da absorção dos nutrientes minerais é a raīz. Assim è que hā muito o fị lósofo e biōlogo Aristōteles jā tinha idéias de como as plantas se alimentavam: seria a planta um animal invertido, no sentido de manter a boca no chão. 
"Absorpcion" e "uptake" são os termos usados na literatura estrangeira geralmente para expressar a entrada de uma substância den tro da célula vegetal, tecido ou órgão, por qualquer mecanismo (ROBERTSON, 1951).

A constatação da necessidade de se fornecer nutrientes às plantas data da era antes de Cristo. 0 uso de fertilizantes, jā era hábito entre os chineses, gregos e romanos (COELHO e VERLENGIA, 1971).

A absorção e movimento de agua e sais atravēs das plantas foram estudados no século XVIII. Stephen Hales (1769), citado por CRAFTS (1961), executou vārios experimentos nos quais mediu a quantidade de āgua transpirada pelas plantas. Estudou tambēm a absorção de āgua pelas raizes e ramos destacados.

0 conhecimento sobre o papel dos elementos minerais na nutrição das plantas desenvolveu-se lentamente desde o trabalho de Lavoisier, Ingenhousz e Senebier (RUSSEL, 1927). De Saussure, citado por CRAFTS (1961), baseando estudos nestes trabalhos anteriores, encontrou que os elementos minerais são incorporados dentro da planta como o carbono; evidenciou a essencialidade do nitrato para as plantas superiores e que o nitrogênio utilizado pelas plantas vinha do solo e não da atmosfera.

Ele indicou que as plantas absorvem muito mais água do solo do que suas exigências para o crescimento e que absorvem determinados elementos minerais do solo não exigidos para o crescimento (elementos não essenciais); as plantas, absorvem também, minerais do solo 
em proporções diferentes de suas ocorrências na solução do solo.

Knop e Sachs (sem data), citados por MAXIMOV (1946), esclareceram a indispensabilidade para a nutrição das plantas do K, Ca,Mg, Fe, S, P e N.

Embora o uso de fertilizantes remonta da era antes de Cris to, somente com Liebig (1840), citado por MALAVOLTA et alii (1967), iniciou-se a aplicação química na agricultura. A ênfase era com relação às produtividades das culturas e pouca atenção se deu ao mecanismo pelo qual as plantas obtinham o nutriente do solo.

Durante muito tempo se considerou a absorção radicular de sais como um simples processo de difusão destes desde o solo. Atribuiu-se grande importância sobretudo a chamada "Corrente transpiratōria", ou seja, o movimento da āgua desde o solo às raízes e destas, ao longo do caule, atē as folhas em virtude da evaporação continuada de āgua na folhagem (MAXIMOV, 1946).

Em memorāvel documento HOAGLAND e DAVIS (1923) relataram sobre os experimentos com uma alga de água doce, Nitella, cujas células apresentavam alguns centỉmetros de comprimento, permitindo a fáciī remoção do suco celular para anālise, Os resultados foram comparados aos da anālise da água na qual as plantas estavam crescendo. Evidenciou-se que os elementos determinados no suco celular, a excessão do nitrogēnio, estavam presentes em mais alta concentração que na āgua do reservatōrio.

Dos muitos trabalhos sobre a acumulação de sais pelas raí zes das plantas, HOAGLAND (1937), concluiu que a acumulação dos sais é 
dependente das atividades metabōlicas das células das plantas, associada com a respiração e refletida na produção de $\mathrm{CO}_{2}$.

Com relação a absorção de nutrientes pelas plantas em fun ção do seu ciclo, HORNBERGER (1882), na Alemanha, divulgou os resultados de um estudo sobre 0 curso da absorção de nutrientes pelo milho. LIEBSCHER (1887) aprofundou ainda mais a teoria e o valor de tais estudos. Ou tros trabalhos foram realizados posteriormente com vārias culturas atravēs de SNYBER (1893), com trigo; BURD (1919), e BRENCHLEY (1929), ambos com cevada; CHAPMAN e PARQUUER (1942) e ROY e GARDNER (1946), com a laranjeira; NORMAN (1944) e MASCARENHAS (1972), ambos com a soja; SARRUGE et alii (1963), com algodoeiro; AVILAN (1971), com a mangueira, CASTRO et alii (1975), com guaranazeiro e FERNANDES et alii (1977) com maracujazeiro. Alēm desses, WALQUER (1960), apresentou uma excelente revisão quanto a absorção de ions pelas plantas.

Com relação ao cafeeiro, as primeiras investigações realizadas no exterior devem-se a ANSTEAD e PITTOCK (1913) que estudaram a absorção de nutrientes pelos frutos atravēs da variação no conteudo mineral das cerejas durante o desenvolvimento.

Segundo SAMUELS (1957), o cafeeiro absorve os nutrientes que necessita para seu crescimento, sendo que um dos aspectos do crescimento é o desenvolvimento das cerejas para as colheitas; ao iniciar a produção, o cafeeiro passa a ter duas bocas a alimentar. A primeira seria para a formação de cerejas para a prōxima safra e a segunda, necessāria ao crescimento da árvore em si, ou seja, para a formação de novos ramos, folhas, etc. 
LOUE (1958), observou maior absorção de nutrientes pelo cafeeiro no perīodo de vegetação intensa; encontrou maiores teores folia res de $N$ e $P$ nesta época. A nutrição potāssica encontra-se no máximo, no perĩodo chuvoso e com relação ao cálcio, o teor foliar é máximo no período de seca.

PARRA et alii (1962), estudaram a absorção de radiofōsforo pelo cafeeiro atravēs de vārios modos de aplicação, concluindo que a maior absorção se conseguiu incorporando superficialmente ao solo a $30 \mathrm{~cm}$ do tronco.

No perĩodo de crescimento os nîveis foliares são mais altos devido a maior atividade fisiológica da planta caracterizada pela maior absorção de nutrientes minerais e nenhuma perda das reservas nutri cionais. (HUERTA, 1963).

HART (1966), evidenciou a necessidade de utilização de fertilizantes em Cafeeiros na Nova Guinē e detalhou a respeito da extração de nutrientes pelas folhas, polpas, sementes e cerejas maduras.

Na Uganda, STEPHENS (1967), correlacionou produtividade de cafeeiro com fertilidade do solo e encontrou produtividades significativamente relacionadas ao $\mathrm{pH}$ ou teores de $\mathrm{K}$ trocāvel.

CARVAJAL et alii (1969), constataram a absorção lĩquida dos elementos minerais maiores (macronutrientes) com excessão do enxofre, por plantas de café (Coffea arabica var. Bourbon) durante um ciclo vegetativo e reprodutor completo. A contribuição por parte dos nutrientes estudados ao total da absorção líquida indicou claramente que 0 
nitrogênio é o elemento quantitativamente mais importante na nutrição do café, seguido do potāssio. A contribuição deses elementos ao total absorvido foi de 48 e $28 \%$ respectivamente. Observaram ainda que cada nutriente está sujeito a um padrão de absorção "sui generis" durante 0 ano.

Jā na dēcada de 70, CANNELL e KIMEU (1971), estudando a absorção e distribuição de macronutrientes em cafeeiros no Kenya, constataram que o conteudo total de nutrientes das partes vegetativas das plantas foram geralmente na seguinte ordem: folhas > ramos > raizes > tron co. Verificaram ainda que a planta madura ( 1 planta $\pm 4^{1 / 2}$ anos de idade) retira cerca de $100,0 \mathrm{~g} \mathrm{~N} ; 6,0 \mathrm{~g} \mathrm{P} ; 100,0 \mathrm{~g} \mathrm{~K} ; 35,0 \mathrm{~g} \mathrm{Ca}$ e $10,0 \mathrm{~g} \mathrm{Mg}$ por ano, dos quais $9-29 \%$ (dependendo do elemento) são removidos por uma produção média de frutos. Assim, calcularam que $1100 \mathrm{~kg}$ de café em coco, retiram aproximadamente $23,0 \mathrm{~kg} \mathrm{~N} ; 1,7 \mathrm{Kg} \mathrm{P} ; 29,0 \mathrm{~kg} \mathrm{~K} ; 2,7 \mathrm{Kg} \mathrm{Ca}$; $2,0 \mathrm{~kg} \mathrm{Mg} \mathrm{e} \mathrm{2,3} \mathrm{kg} \mathrm{S.}$

GOPAL et alii (1976), verificaram que a absorção e translocação de $\mathrm{P}^{32}$ de folhas aplicadas foram consideravelmente mais altas no arábica cv. S.795 que no robusta cv. 274. Isto sugeriu que as necessidades de $P$ durante o desenvolvimento do botão floral e anteses è maior no aräbica que no robusta.

KUMAR (1979), apresentou uma excelente revisão da literatura disponível sobre o relacionamento entre umidade do solo e variação diária no estado de água da planta, condutância foliar, fotossīntese, absorção de NPK, crescimento e produções, absorção mineral em relação ã seca e a resposta do cefeeiro a aplicação tardia de $\mathrm{N}$. 
Estudando o efeito da umidade do solo sobre a absorção mi neral de potāssio e nitrogênio e crescimento do coffea arabica, TESHA e KUMAR (1979) constataram que a absorção de N e K não foi afetada pelo nI vel de umidade atē $50 \%$ da capacidade de campo, porém abaixo de $50 \%$, a absorção de $\mathrm{N}$ e $\mathrm{K}$ foi lenta. A absorção de $\mathrm{P}$ não foi afetada pelo nFvel de umidade do solo. Notou-se uma interação positiva entre $\mathrm{N}$ e $\mathrm{K}$ e uma negativa entre $N$ e $P$. A absorção de nutrientes relacionou-se com a quantidade aplicada. A nutrição em $\mathrm{N}$ e $\mathrm{K}$ aumentou mais o desenvolvimento do caule e a área foliar. A nutrição em N, aumentou o número de nós (nōdulos).

Já ORUKO e GATITU (1970), compararam em cafeeiros, os efeitos do $\mathrm{K}$ e $\mathrm{Mg}$ em diversos nỉveis e encontraram marcada interação entre $\mathrm{K}$ e Mg sobre o desenvolvimento da planta (diâmetro da planta). Altos niveis de $\mathrm{K}$ e baixo em $\mathrm{Mg}$, resultou em morte dos ramos e queda das foThas, especialmente durante a frutificação.

Quanto ao uso de NPK, influenciando a produção de cofbrea arabica, MATHEW e RAO (1980) fizeram uma revisão e discussão em torno do assunto.

NJAGI (1980), estudando o uso econômico de fertilizantes na produção de café, encontrou relação entre a quantidade de fertilizante nitrogenado usado, incremento na produtividadee economicidade.

No Brasil, seguramente coube a DAFERT (1895), os primeiros estudos sobre a nutrição do cafeeiro. Este pesquisador verificou a extração de nutrientes pela raīz, caule, ramos e frutos. Posteriormente 
CATANI e MORAES (1958), investigando a composição química do cafeeiro, concluĩram que as quantidades médias dos elementos retiradas por uma planta com cinco anos de idade foram de $117,5 \mathrm{~g} \mathrm{~N} ; 16,4 \mathrm{gP}_{2} \mathrm{O}_{5} ; 121,3 \mathrm{~g} \mathrm{~K} 2 \mathrm{O}$; $77, \mathrm{~g} \mathrm{CaO}$ e $23,5 \mathrm{~g} \mathrm{MgO}$. Dessas quantidades totais, os frutos foram responsāveis pela retirada de $33,4 \mathrm{~g} \mathrm{~N} ; 5,04 \mathrm{~g} \mathrm{P}_{2} \mathrm{O}_{5} ; 42,52 \mathrm{~g} \mathrm{~K} \mathrm{~K}_{2} \mathrm{O} ; 5,21 \mathrm{~g} \mathrm{CaO}$ e $5,54 \mathrm{~g}$ MgO. Em termos percentuais, os frutos seriam responsāveis por cer ca de $28 \%$ de todo $\mathrm{N}$ contido na planta; $31 \%$ de todo $\mathrm{P}$; $35 \%$ de todo $\mathrm{K}$; $7 \%$ de todo $\mathrm{Ca}$ e $23 \%$ de todo $\mathrm{Mg}$.

CATANI et alii (1965), continuando suas pesquisas sobre a nuţrição do cafeeiro, verificaram que as quantidades de macronutrientes absorvidas pelo cafeeiro var. Mundo Novo aos dez anos de idade foi de $219,3 \mathrm{Kg} \mathrm{N} ; 15,5 \mathrm{~kg} \mathrm{P} ; 179,0 \mathrm{Kg} \mathrm{K} ; 135,5 \mathrm{Kg} \mathrm{Ca} ; 29,4 \mathrm{~kg} \mathrm{Mg} \mathrm{e} 23,6 \mathrm{Kg} \mathrm{S}$. Por outro 1 ado, a produção de frutos no ano em que o cafeeiro completava dez anos de idade exigiu $21,0 \mathrm{~g} \mathrm{~N} ; 2,1 \mathrm{~g} \mathrm{P} ; 26,7 \mathrm{~g} \mathrm{~K} ; 2,7 \mathrm{~g} \mathrm{Ca} ; 1,7 \mathrm{~g} \mathrm{Mg} \mathrm{e}$ $1,4 \mathrm{~g} \mathrm{~S}$.

ARZOLLA et alii (1963), calcularam as quantidades de elementos extraîdas por uma saca de café beneficiado (60 kg grãos) em $1026,0 \mathrm{~g} \mathrm{~N} ; 60,0 \mathrm{~g} \mathrm{P} ; 920,0 \mathrm{~g} \mathrm{~K} ; 162,0 \mathrm{~g} \mathrm{Ca} ; 90,0 \mathrm{~g} \mathrm{Mg} \mathrm{e} 720,0 \mathrm{~g} \mathrm{~S}$.

Segundo CATANI et alii (1967a), as quantidades de micronutrientes, extraídas pelo cafeeiro variedade Mundo Novo, aos dez anos de idade, para o desenvolvimento de seu tronco, ramos e folhas foi de 555 , Omg B; 37157, Omg Cl; 214 , Omg Cu; 3765,Omg Fe; 776, Omg Mn, 1,6mg Mo e 144,0mg $\mathrm{Zn}$. A quantidade de alumīnio extraída foi de $2068,0 \mathrm{mg}$. A extra ção de micronutrientes promovida pelos frutos pode ser calculada, tomando-se como $2000 \mathrm{~kg}$ de cafē em coco a produção de 1000 covas. A quantidade 
removida foi $24,0 \mathrm{~g} \mathrm{~B} ; 3380 \mathrm{~g} \mathrm{Cl} ; 21,0 \mathrm{~g} \mathrm{Cu} ; 55,0 \mathrm{~g} \mathrm{Fe} ; 19,0 \mathrm{~g} \mathrm{Mn} ; 11,0 \mathrm{~g} \mathrm{Zn} \mathrm{e}$ $0,15 \mathrm{~g}$ Mo.

De acordo com MORAES e CATANI (1964), a percentagem de matéria seca aumentou à medida do desenvolvimento do fruto, observandose 0 inverso com os elementos minerais. Houve um grande aumento na acumulação de NPK e matēria seca no fruto durante as ūltimas semanas que antecederam o final da maturação. Com relação a assimilação de NPK, nos últimos 60 dias os frutos apresentaram um aumento da ordem de 49,36 e $39 \%$ respectivamente do total existente no fruto, quando este atingiu a maturação completa.

Parte dos resultados alcançados por MORAES e CATANI(1964), foram corroborados por CATANI et alii (1967b), verificando ainda estes autores que todos os macro e micronutrientes, ferro, cobre, boro e molibdênio, foram exigidos continuamente durante todo o ciclo formativo do fruto. 0 zinco e manganēs não foram exigidos em quantidades crescentes nos estágios finais do desenvolvimento. 0 potāssio contribuiu com $52 \%$ e 0 nitrogênio com $34 \%$ da quantidade total de macronutrientes acumulada. o Fe correspondeu a $39 \%$ e o $\mathrm{Mn}$ a $33 \%$ da quantidade total de micronutrien tes acumulada.

SILVA e SOUZA et alii (1975), a exemplo de MORAES e CATANI (1964), também constataram que as percentagens dos elementos Ca, $P_{\text {, }}$ $K$ e Mg declinavam à medida do desenvolvimento dos frutos. Jā o Mn manteve-se relativamente estāvel.

MENARD e MALAVOLTA (1957), estudando o fornecimento de $\mathrm{p}^{32}$ em mudas de café verificaram que apōs 24 horas, $14,7 \%$ do material 
ativo havia sido absorvido. A percentagem elevou-se para $30,8 \%$ em 48 ho ras e $68,7 \%$ em seis semanas.

MALAVOLTA et alii (1959), comparando formas de fornecimen to de superfosfato para o cafeeiro em Terra Roxa misturada, concluiram que a absorção do $\mathrm{P}^{32}$ foi mais intensa quando fornecido à superfīcie do solo.

SARRUGE et alii (1966), suprindo $P^{32}$ em cafeeiros jovens, via radicular e foliar, observaram que a absorção foi muito mais rápida, mediante a aplicação foliar que radicular.

Quanto a absorção do radiozinco, segundo ARZOLLA (1955), quando aplicado diretamente nas folhas chegou a ser oito vezes mais intensa que no caso do fornecimento à solução nutritiva (radicular). A aplicação na pāgina inferior da folha foi mais eficiente; cerca de $40 \%$ do Zn aplicado foi absorvido.

ARZOLLA et alii (1955-1956) verificaram que a absorção de Zn por cafeeiros não foi afetada pela variação na concentração de $\mathrm{Fe}$ na solução nutritiva no intervalo de 0 a $10 \mathrm{ppm}$, mas foi aproximadamente a metade pelo aumento na concentração de $\mathrm{Mn}$ de 0,5 para 5,0 ppm, $\mathrm{Cu}$ de 0,02 a $0,2 \mathrm{ppm}$ ou Mo de 0,01 a $0,1 \mathrm{ppm}$. Quando o Cu foi omitido, a absorção de $\mathrm{Zn}$ aumentou.

HAAG e SARRUGE (1967), estudando a absorção de Zn por raĩ zes destacadas de cafeeiro, concluīram que o processo de absorção de Zn é um fenômeno metabōlico, podendo ser inibido pela presença de venenos respiratōrios. A presença de cálcio na concentração de $10^{-5} \mathrm{M}$ teve 
efeito estimulatório na absorçã́o de $Z n$. B oư Fe estimularam a absorção de $\mathrm{Zn}$; o Cu exerceu efeito antagônico na absorção de $Z n$.

AMORIN et alii (1968), estudando o efeito da variação do $\mathrm{pH}(4,0$ a 7,5$)$ no desenvolvimento e composição química do cafeeirolcob́lea arabica L., var. Mundo Novo) cultivado em solução nutritiva constataram que a absorção de macronutrientes diminuiu com o aumento do $\mathrm{pH}$, sendo que a melhor faixa para o crescimento em altura, número de folhas, peso da matéria fresca e seca foi o de 4,0 a 6,0.

GODOY JUNIOR e GRANER (1970), encontraram efeito benéfico do uso de fertilizantes quanto a produção, rendimento de café coco em ca fē beneficiado, peneira média, etc.

\subsubsection{Redistribuição de Nutrientes}

E conhecido desde muito tempo que alguns nutrientes minerais se redistribuem nas plantas, movendo de folhas maduras para folhas jovens em crescimento e para o meristema apical. Assim é que uma planta abundantemente alimentada com fosfato, pode posteriormente crescer atē a maturidade em solo deficiente de fósforo (CRAFTS e CRISP, 1971).

Uma "fonte", seja uma folha madura, pode estar localizada entre dois reservatórios, por exemplo: uma folha nova em desenvolvimento rāpido no ramo, acima dela e um fruto em crescimento, abaixo. Pode o assimilado da "folha fonte" mover-se na direção dos dois reservatōrios? Em outras palavras: pode haver movimento bidirecional do carbohidrato no floema do caule? Mason et alii (1936) e Phillis e Mason (1936), verificaram que a resposta é sim (EPSTEIN, 1.975). 
Coube a Marcellus Malpighi $(1675,1679)$, as primeiras observações sobre o movimento ascendente e descendente das substāncias no caule através dos vasos, ocorrendo no lenho e no cortex (casca) (CRAFTS, 1961). Apōs isso, muitos trabalhos foram realizados por pesquisadores tentando explicar o movimento de água e nutrientes dentro da planta. Os conhecimentos sobre o mecanismo do processo foram ampliados consideravelmente apōs as clāssicas investigações do inglēs Hales em 1727 (MAXIMOV, 1946).

MILTHORPE e MOORBY (1969), revisando o assunto, verificaram que dos ions que chegam à folha, apreciāveis quantidades são retrans locadas via floema, sendo o grau de mobilidade provavelmente determinado pela velocidade do movimento dentro e fora do floema. 0 fósforo é particularmente mōvel. A maior parte que chega às folhas muito novas vem das folhas velhas, mas a maior parte que é importada para rápida expansão e maturação das folhas vem diretamente das raîzes. A translocação pa rece ser controlada pela folha fonte. 0 potāssio tem uma mobilidade similar àquela do fósforo. A circulação do sōdio e cloreto é muito baixa. Aparentemente os íons cálcio não podem entrar nos tubos crivosos porque são preferentemente absorvidos nos sítios extremos do floema. Algum movimento pode ser detectado com altas concentrações de cálcio, quando pos sivelmente estes sítios estão saturados, ou com adição de ĩons hidrogēnio ou agentes quelantes.

Segundo MITCHELL et alli (1960), o movimento do ion para baixo, ocorre apōs a aplicação de nitrogēnio, fósforo, ferro, magnẹsio e alguns outros elementos à folhagem. Os ĩons podem também moverem-se 
para fora de uma determinada folha se a deficienncia de um dado elemento desenvolve-se em outra parte da planta ou se a folha se torna velha (senescente). Evidēncias tem sido obtidas com elementos radioativos ou com compostos contendo elementos radioativos, indicando que o movimento dos ions das folhas è via floema. Quando um íon chega ao caule, ele pode continuar em uma direção para cima ou para baixo no floema. Interessantemente, se dois ou mais ỉons são supridos à folha, seus movimentos no floema do caule podem ser em diferentes direções simultaneamente ou na mesma direção, mas em velocidades diferentes.

A velocidade de movimento dos Tons no floema é muito alta para ser explicado com base na simples difusão. Radiofósforo e fotossin tatos tem sido observados moverem-se para baixo no floema a velocidades de 21 e $100 \mathrm{~cm}$ por hora respectivamente.

BIDDULPH (1941), trabalhando com feijoeiro, concluiu que havia migração do $\mathrm{P}^{32}$ das folhas, sendo inicialmente a direção de migração predominantemente para baixo.

BIDDULPH e MARKLE (1944), com algodoeiro, constataram que o radiofósforo moveu via floema, caminhando da folha para outras partes da planta. A velocidade de movimento em direção para baixo foi de $21 \mathrm{~cm}$ por hora. O movimento no floema foi muito variado e envolvendo desde praticamente nada atē mais de $40 \%$ do fosfato móvel, sugerindo que outros fatores internos desconhecidos podem controlar a velocidade e direção do movimento. 
WITHNER (1949), estudou a distribuição de $P^{32}$ em plantas maduras de milho atravēs da aplicação de traçador como fosfato na raiz. BUKOVAC e WITTWER (1957), estudaram a mobilidade de vărios elementos minerais marcados, aplicados às folhas de feijoeiro e apresentaram a classificação seguinte:

Movel

Rubīdio $\mathrm{Rb}^{86}$

Sódio $\quad \mathrm{Na}^{22}$

Potássio $\mathrm{K}^{42}$

Fósforo $p^{32}$

Cloro $\mathrm{Cl}^{36}$

Enxofre $\mathrm{s}^{35}$

\section{Parcialmente Móvel}

Ferro $\mathrm{Fe}^{55-59}$

Molibdēnio Mo 99

Zinco $\quad \mathrm{nn}^{65}$

Cobre $\mathrm{Cu}^{64}$

Manganẽs Mn 52-54

verifica-se que aos micronutrientes è consignada uma posição intermediāria.

BIDDULPH et alii (1958), determinaram os padrões de distribuição de $\mathrm{P}^{32}, \mathrm{~s}^{35}$ e $\mathrm{Ca}{ }^{45}$ em feijão quando traçadores foram aplicados às raizes por uma hora e amostras foram autoradiografadas em perĩodos de $0,6,12,24,48$ e 96 horas apōs a remoção dos traçadores, 0 cálcio sen do praticamente imōvel no floema, foi usado como base de comparação da distribuição do enxofre e fósforo, Foi encontrado alta mobilidade para o fósforo, corroborando os resultados encontrados por BUKOVAL e WITTWER (1957), porém para o enxofre foi considerado apenas como sendo de moderada redistribuição. 
O Fe geralmente è considerado ser imóvel nas plantas, uma vez incorporado na folha não serā redistribuido para tecidos jovens. Experimentação na qual. o sulfato de ferro foi pulverizado a plantas cloróticas de Sorghum vulgare, indicou que hā algum movimento; algumas das folhas novas anteriormente clorōticas, tornaram-se verdes (CRAFTS e CRISP, 1971).

BROWN et alii (1965), pulverizaram $\mathrm{Fe}^{59}$ em folhas de plan tas jovens de Sorghum. 0 tratamento foi por 3 dias. Autoradiografias de folhas tratadas, mostraram translocação no apoplasto e simplasto. A concentração de $\mathrm{Fe}^{59}$ na ponta da raiz e folhas novas foi alta e nas folhas velhas foi baixa.

Os autores concluīram que o $\mathrm{Fe}^{59}$ é parcialmente móvel em plantas novas.

Estes resultados, não estão de acordo com Gile e Carrero (1916), citados por MENARD (1956), os quais verificaram a imobilidade do ferro na planta, considerando-o como elemento que não se redistribui.

Quanto ao boro, McILRATH (1965), verificou sua imobilidade no floema em vārias espécies de dicotiledōneas.

STEUCEK e KOONTZ (1970), encontraram que o $\mathrm{Mg}^{28}$ foi mais móvel que o cálcio no floema, porēm menos mōvel que o potássio, no feijoeiro.

Panak e Szafranck (1967), citados por CRAFTS e CRISP(1971), aplicaram $S^{35}$ à folbagem que exibiram limitado transporte simplástico às raizes e folhas jovens. 
KOLLER (1975), estudando a influência do virus da tristeza dos citros sobre a absorção e translocação do zinco, concluiu que a presença do virus nas plantas intolerantes, ocasionou migração do $\mathrm{Zn}$ das folhas velhas, sendo mais acentuado nas copas de limoeiro galego.

AVILAN (1971), estudando os niveis de alguns macronutrientes nas folhas de manga (Mangifera indica Linn), encontrou que durante o perīodo de formação dos frutos, o teor dos elementos é mais baixo. Provavelmente houve redistribuiç̧ão dos elementos das folhas para os frutos em crescimento.

Segundo MALAVOLTA (1979), um fruto na adjacēncia da foTha pode afetar o teor da maior parte dos elementos na mesma. Por outro lado a carga ou produção é capaz de influenciar até mesmo a composição das folhas situadas em ramos não portadores de frutos.

Reuther et alii, citados por MALAVOLTA (1979), mostram o efeito da frutificação na composição mineral de folhas de laranjeiras. Os teores de $\mathrm{N}, \mathrm{P}, \mathrm{K}$ e $\mathrm{Mg}$ de ramos sem frutos foram sempre maiores que de ramos com frutos.

Com relação ao cafeeiro, poucos trabalhos foram realizados nesta área e entre eles podemos citar o de PEREIRA et alii (1963), que estudaram a absorção e translocação de moléculas orgânicas e elementos minerais, utilizando materiais radioativos, Entre outras conclusões vale a pena ressaltar as seguintes:

- $0 C^{14}$ da uréia se move no floema desde as folhas fotossinteticamente ativas, provavelmente na forma de sacarose. Nas folhas 
não iluminadas o faz principalmente em forma acrópeta, podendo mover-se como nolécula intacta ou como um complexo de uréia e provavelmente não como sacarose, senão atē que alcance as folhas iluminadas.

- $0 \mathrm{Ca}^{45}$ não é movel no floema; ē de alta absorção pelas raizes. As células das folhas tem uma forte tendência a acumular e fixar cālcio.

- $0 \mathrm{Zn}^{65}$ se move no café em menor proporção que em outras plantas.

- A penetração foliar do $P^{32}$ é lenta; altamente acumulado pelas raīzes e de menor movimento que o cālcio em direção às folhas atra vēs do xilema.

CANNELL e HUXLEY (1969), investigando as diferenças estacionais no padrão de movimento de assimilados em ramos de Coff́ea arabica L., constataram atravēs de autoradiografias que $C^{14}$ das folhas tratadas acumularam variavelmente no broto apical, folhas em crescimento e em alguns frutos.

GOPAL et alii (1976), verificaram translocação mais al ta de $\mathrm{P}^{32}$ na espécie arābica que no robusta.

PEREIRA e YAMAGUCHI (1964), aplicaram arseniato de amōnio contendo $\mathrm{As}^{77}$ em plantas de café via foliar. Não observaram translocação do As aplicado em folhas imaturas, Das folhas recēm maduras a trans locação (redistribuição) foi predominantemente acrōpeta em direção às fo Thas em crescimento. Aplicação em folhas velhas resultou na translocação para baixo acumulando nas pontas das raîzes. 
MULLER (1959), analisando folhas de café de diversas idades em um mesmo ramo verificou teores mais elevados de $\mathrm{N}, \mathrm{P}, \mathrm{K}$ e $\mathrm{Mg}$ nas folhas mais novas. Concluiu que esses elementos são redistribuidos facilmente das folhas mais velhas aos frutos e provavelmente também às foThas mais novas. Este processo determina um esgotamento quase completo das folhas mais velhas.

Segundo HUERTA (1963), na época de produção, os nīveis de elementos na folha do cafeeiro são mais baixos por efeito da redistribuição das reservas das folhas atē os frutos em crescimento. Portanto deve-se esperar nîveis mais baixos para o mesmo par foliar durante o perĩodo de maturação dos frutos.

A quantidade de nutrientes redistribuîdos até os frutos se efetua na base das reservas acumuladas das folhas diminuindo em consequência os nivveis foliares. As reservas de nutrientes se redistribuem até os frutos desde todos os pares de folhas. Possivelmente o ritmo de redi stribuição seja mais intenso em determinados pares e por conseguinte as diferenças dos nîveis minerais antes e na maturação dos frutos sejam de maior amplitude.

CANNEL e KIMEU (1971), constataram em cafeeiros no Kenya, que as folhas novas, sempre que analisadas, apresentavam teores mais ele vados em todos os nutrientes, exceto $\mathrm{Ca}$ que era mais rico nas folhas veThas .

No Brasil, raríssimos são os trabalhos visando o estudo da redistribuição dos elementos na planta, principalmente com cultura do café. 
MENARD e MALAVOLTA (1957), estudando a absorçäo e distribuição do fósforo radioativo no cafeeiro, verificaram que a acumulação foi particularmente alta em raizes secundārias e nas partes veihas do caule. Folhas novas acumularam mais que as velhas e os vasos e peciolos se apresentaram mais ricos que as regiões internervais em $\mathrm{P}^{32}$.

SARRUGE et alii (1966), observaram translocação muito mais rāpida do $\mathrm{P}^{32}$ mediante aplicação foliar que radicular.

MALAVOLTA et alii (1959), estudando o modo de fornecimento de $P^{32}$ observou que as folhas do cafeeiro absorvem o radiofósforo e que este se transloca para outros órgäos da planta. Notou-se que as atividades/unidade de peso foram mais al tas nos örgãos novos, isto é, o caule e as folhas acima ou apostas àquelas que receberam o fósforo radioativo. Isto significa que a translocação foi mais intensa para os te cidos metabolicamente ativos.

ARZOLLA (1955-56), verificou que aproximadamente $12 \%$ do zinco aplicado às folhas de cafeeiros, translocou-se principalmente para baixo.

SILVA e SILVA (1956), analisando folhas de café colhidas de ramos com frutos e ramos sem frutos verificaram que as folhas de ramos sem frutos são mais ricas em nitrogênio com diferença de $0,23 \%$. 0 mesmo aconteceu em potássio e fósforo, sendo as diferenças de $0,51 \%$ e $0,013 \%$ respectivamente.

Quanto ao cāicio e magnésio, foram constatados que as foThas de ramos sem frutos são mais pobres sendo as diferenças de $0,26 \%$ e $0,03 \%$ respectivamente. 


\subsection{Composi ição Quĩmica}

0 cafeeiro é planta que apresenta alta exigência em nutrientes minerais. Segundo MALAVOLTA (1974), as exigēncias do cafeeiro aumentam segundo sua idade. Por volta dos 3 anos esta exigência duplica, o que deve ser quase exclusivamente ao início da produção de grãos.

Muitos trabalhos tem sido realizados com vārias culturas, visando a determinação da sua composição quỉmica. Assim, podemos citar SARRUGE et alii (1963), com algodoeiro; BATAGLIA (1977); TAKIDZE (1981), com laranjeira; SHEAR e SMITH (1969); ZEIGER e SHELTON (1969), com macieira; DROVER (1970), com cacaueiro; AVILAN (1971), com mangueira; SOLORZANO e BORNEMISZA (1976), com mandioca; FERNANDES et alii (1977), com maracujazeiro e CAHOON (1980), com videira.

Com relação ao cafeeiro, um dos primeiros trabalhos realizados no exterior foi executado por ANSTEAD e PITTOCK (1913), os quais estudaram a composição quîmica dos frutos de café durante o seu perĩodo de desenvolvimento.

LOUE (1957), encontrou teores mais elevados de N no grão do que na polpa para Coffea canephora var. Robusta. Quando comparou a composição mineral do C. canephora com C. arabica, verificou haver gran de diferença.

Parte desses resultados foram corroborados por VASUDEVA e GOPAL (1977), que analisaram o conteudo de $\mathrm{N}$ na polpa, mucilagem e sementes de C. arabica, C. canephora e C.dewerdi, concluindo que as semen tes contem mais $\mathrm{N}$ que os demais componentes. Por outro lado numa anālise 
de bebida, verificaram que altas quantidades de $\mathrm{N}$ nas sementes depreciam a qualidade da bebida. Excessivo conteudo de $\mathrm{N}$ nas sementes tende a acu mular mais cafeina, desde que o $N$ é uma das fontes para a sintese de cafeina.

Quanto ao teor de cafeina, efeito semelhante do N foi observado por MIRANDA (sem data).

VERLIẺRE (1973a), estudando a nutrição do cafeeiro, verificou que os elementos K, Ca e Mg são mais elevados na polpa que no grão. Quanto ao $\mathrm{N}$ e $\mathrm{P}$, estes são mais ricos na semente.

RAMAIAH e VASUDEVA (1969), conduziram estudos fisiolōgicos sobre o crescimentoe de frutos de coffea arabica L. com respeito ao incremento do peso de matēria fresca, peso da matéria seca e acumulação de nitrogēnio de diferentes partes do fruto, desde o estádio de "chumbinho" atē a maturação. Os resultados foram comparados com o crescimento das cerejas do Coffea canephora. Observaram-se 3 periodos distintos para a acumulação de $\mathrm{N}$ no caso do $\mathrm{C}$. arabica; no entanto se registrou um tipo linear de crescimento no caso do $C$. canephora. Este fenōmeno se sucedeu tanto para a cereja inteira como para o endosperma separadamente. No C. arabica, apōs uma alta acumulação inicial de $\mathrm{N}$ na casca, aparece uma queda a qual pode ser devido a redistribuição do $\mathrm{N}$ a diferentes partes. Uma preferencial acumulação de $\mathrm{N}$ pelo endosperma foi notificada aos 152 dias (apōs florescimento).

No fruto como um todo (polpa + sementes) em termos percentuais atē aproximadamente 102 a 117 dias(apōs o florescimento), acumulou $50 \%$ do $\mathrm{N}$; desse perīodo até os 167 dias, acumulou $67 \%$, daĩ até o 
final da maturação completou os $100 \%$.

CANNEL e KIMEU (1971), estudando a absorção e distribuição de macronutrientes em cafeeiros, verificaram que a composição média de planta com remoção do botão floral foi de $0,092 \% \mathrm{P} ; 0,167 \% \mathrm{Mg} ; 0,51 \% \mathrm{Ca}$; $1,29 \% \mathrm{~K}$ e $1,54 \% \mathrm{~N}$ orgânico. Proporcionalmente seria: 1 P: 1,8 Mg: 5,5 Ca: $14 \mathrm{~K}: 17 \mathrm{~N}$. As folhas continham maior percentagem de nutrientes que 0 lenho e raizes, com duas notāveis excessões. Os ramos foram mais ricos em $P$ que folhas velhas $(0,128 \% P$ nos ramos e $0,108 \%$ nas folhas velhas) e as raizes finas (< $3 \mathrm{~mm}$ diâmetro) foram igualmente ricas em $\mathrm{Mg}$. Com relação a soma de cations nas folhas velhas foi de $42 \% \mathrm{~K} ; 41 \% \mathrm{Ca}$ e $16 \% \mathrm{Mg}$, mas em plantas com frutificação o teor foliar foi de $36 \% \mathrm{~K} ; 50 \% \mathrm{Ca}$ e $14 \% \mathrm{Mg}$.

ADUAYI (1971), verificando o efeito do Cu sobre o crescimento e conteudo de macronutrientes em mudas de café, constatou que au mentando os nīveis de Cu diminuiu a concentração de $\mathrm{N}, \mathrm{K}$ e $\mathrm{Ca}$ em folhas de coffea arabica; aumentou 0 teor de $\mathrm{N}$ e diminuiu o de $\mathrm{P}$ no tronco $\mathrm{e}$ ramos. A concentração de $\mathrm{N}, \mathrm{P}$ e Mg nas raizes também diminuiu.

Analisando diversas partes do cafeeiro KOSS et alii(1973), encontraram as seguintes concentrações de Cu: folhas (2l-22 ppm), caule (40 ppm), raizes (80 ppm) e ramos laterais (75-100 ppm).

SAMUELS e CAPO (1952), estudando o efeito de um elemento fertilizante sobre a absorção e concentração deste elemento e de outros na planta, observaram com relação ao café que a adição de $\mathrm{N}$ ao solo, não afetou significativamente a concentração foliar de $\mathrm{P}, \mathrm{K}$ e $\mathrm{Ca}$. A aplicação de fósforo diminuiu os nĩveis de Ca nas folhas de café. A adição 
de potássio não afetou a concentração de $N$ e $P$. Uso de nîveis crescentes de cálcio no solo aumentou a concentração de $P$ e $K$ nas folhas e não afetou o nível de $N$.

$$
\text { Por outro lado, FORESTIER e BELEY (1969), estudando }
$$

OS

efeitos de alguns macronutrientes sobre a nutrição mineral e produtividade de cafeeiros robusta, verificaram que o $\mathrm{N}$ aumentou a produção e os teores foliares de N. Baixou o teor foliar de $\mathrm{K}$ e aumentou os de $\mathrm{Ca}$ e Mg. Quanto aos micronutrientes, a adubação nitrogenada aumentou 0 teor de Mn, diminuiu de $\mathrm{Fe}$, Cu e Mo.

Jā ARISTIZABAL e PULGARIN (1977), averiguando o efeito da fertilização com N, P, K na composição mineral das folhas de café, constataram que a aplicação de $\mathrm{N}$ aumentou o teor foliar de $\mathrm{N}$ e $\mathrm{Mg}$ e diminuiu o de $\mathrm{P}$ e $\mathrm{B}$. A aplicação de $\mathrm{P}$ aumentou $\mathrm{o}$ teor de $\mathrm{P}$ e $\mathrm{Mg}, 0 \mathrm{~K}$ reduziu o teor foliar de $\mathrm{Ca}$ e $\mathrm{Mg}$. Teores foliares de $\mathrm{N}$ e $\mathrm{Mg}$ foram positivamente correlacionados com produtividade enquanto que teores de $P$ e B foram negativamente correlacionados,

HUERTAS (1965), encontrou resultado semelhante ao de ARIS TIZABAL e PULGARI (1977) com relação ao efeito do K.

RAO et alii (1979), observaram em mudas de café que a adi ção de cálcio não afetou os teores de P, K, Mg e Fe. Já o teor de Mn de cresceu com a elevação das quantidades de Ca.

Com relação a variação no teor dos elementos, em função da ëpoca, OMATOSO e OLOJOLA (1972), trabalhando com a espécie Coffea canephora Pierre, encontraram variação no teor foliar de macronutrientes 
durante o ciclo do cafeeiro.

BONNET (1969), trabalhando com cafeeiros da variedade "Ca turra" e "Borbon Vermelho" e amostrando folhas em duas épocas: ao final do verão (antes da colheita, no estāgio de desenvolvimento e maturação ds frutos), e ao final do inverno, constatou que no verão os teores foram mais elevados para $\mathrm{N}, \mathrm{K}$ e $\mathrm{Mg}$. Teores semelhantes foram encontrados para $\mathrm{P}$ e micronutrientes ( $\mathrm{Mn}, \mathrm{Fe}, \mathrm{B}, \mathrm{Cu}$ e $\mathrm{Zn}$ ) nas duas épocas. 0 teor de Ca foi mais elevado no inverno.

Já VERLIERE (1973b) encontrou teores foliares de $\mathrm{Fe}$ mais baixos na estação chuvosa e mais elevados na estação seca. 0 Mn segue a mesma tendēncia. $0 \mathrm{Zn}$ apresentou maiores teores no período das chuvas. Segundo MULLER (1959), a composição de uma folha varia durante o processo de envelhecimento. Fazendo-se anālises foliares consecutivas, com certos intervalos de tempo, os resultados mostraram que embora alguns nutrientes minerais aumentem em quantidade conforme aumenta a idade da folha, outros diminuem. 0 grupo de elementos cuja quantidade decresce com a idade é o seguinte: nitrogēnio, potássio, fósforo e às vezes magnésio. 0 grupo que aumenta o conteūdo com a idade da folha, inclue o cālcio, enxofre, ferro, manganês, boro, zinco, cobre e molibdènio.

No Brasil, os primeiros dados sobre a composição química do cafeeiro, foram publicados por DAFERT (1895). Este pesquisador estudou a composição da raiz, caule, ramos, folhas e frutos, assim como a distribuição percentual dos elementos potássio, cālcio, magnésio e 
fósforo em diversas partes do cafeeiro com $1,2,3,4,6,10$ e 40 anos de idade.

CATANI e MORAES (1958), estudando a variação na concentração de N, P, K, Ca e Mg na raiz, tronco, ramos, folhas e frutos do ca feeiro em diversos estādios de seu crescimento, concluiram que houve uma variação periōdica nītida na concentração percentual dos elementos analisados nas folhas e nos frutos. No mês de janeiro, a concentração percentual de N,P, K e Mg foi mais elevada que em julho, excessão feita ao cālcio que nas folhas, pareceu não seguir as mesmas variações dos outros elementos. Nos ramos, tronco e raiz, a variação na concentração dos elementos não foi tão pronunciada quanto a das folhas e frutos e tam bém não seguiu uma periodicidade tão perceptĩvel quanto no caso das foThas e frutos.

SILVA e SILVA (1957), encontraram teores mais elevados de $N, P, K$ e Mg nas folhas de cafē no mês de novembro quando comparado com o mês de janeiro. 0 teor de Ca foi o inverso.

Jā MEDCALF et alii (1955), estudaram a variação mensal do teor de N, P, K, Ca e Mg nas folhas e as produções de café.

Segundo CATANI et alii (1967a), as folhas do cafeeiro constituem a parte mais rica em micronutrientes e o tronco a mais pobre. 0 Mo é o micronutriente que ocorreu em menor concentração, variando de 0,03 a $0,05 \mathrm{ppm}$ no tronco e de 0,21 a $0,23 \mathrm{ppm}$ nas folhas. $\mathrm{OCl}$ apresentou o maior teor, variando de $140-220 \mathrm{ppm}$ no tronco e de $6280-7350 \mathrm{ppm}$ nas folhas. 
A. concentração de micronutrientes nas folhas e frutos mos trou que $\mathrm{O} \mathrm{B}, \mathrm{Cl}, \mathrm{Fe}, \mathrm{Mn}, \mathrm{Mo}, \mathrm{Zn}$ e tambēm o $\mathrm{Al}$ apresentou teores mais elevados nas folhas que nos frutos. $0 \mathrm{Cu}$ apresentou teores semelhantes em ambas as partes.

ARZOLLA et alii (1963), avaliando a extração de macronutrientes na colheita por 3 variedades de café, constatou que a desigualdade na composição dos grãos e da casca foi consistente; o grão tem mais $\mathrm{N}$ e mais $\mathrm{Mg}$ que a casca; esta por sua vez parece ser mais rica nos outros elementos particularmente em potássio.

Já MALAVOLTA et alii (1963), analisando a composição mineral de sementes e polpas das variedades "Borbon Amarelo", "Catuai Amarelo" e "Mundo Novo", acharam as seguintes percentagens no grão: $1,7 \% \mathrm{~N}$; $0,10 \% \mathrm{P} ; 1,53 \% \mathrm{~K} ; 0,27 \% \mathrm{Ca} ; 0,15 \% \mathrm{Mg} ; 0,12 \% \mathrm{~S} ; 16,0 \mathrm{ppm} \mathrm{B} ; 15,0 \mathrm{ppm} \mathrm{Cu}$; $60,0 \mathrm{ppm} \mathrm{Fe} ; 20,0 \mathrm{ppm} \mathrm{Mn;0,05} \mathrm{ppm} \mathrm{Mo;} 12 \mathrm{ppm} \mathrm{Zn}$. Na casca foram as seguintes: $1,78 \% \mathrm{~N} ; 0,14 \% \mathrm{P} ; 3,75 \% \mathrm{~K} ; 0,41 \% \mathrm{Ca} ; 0,13 \% \mathrm{Mg} ; \quad 0,15 \% \mathrm{~S}$; 34,0 ppm B; 18,0 ppm Cu; 150,0 ppm Fe; 29,0 ppm Mn; 0,07 ppm Mo e 70,0 ppm Zn.

AMORIN et alii (1965), obtiveram resultados semelhantes aos de ARZOLLA et alii (1963), constatando teores mais elevados de $N$ no grão do que na polpa. Calcularam esta diferença em torno de $29 \%$. Já a polpa apresentou-se mais rica em $P$ do que o grão em cerca de $15 \%$, sendo tambēm aproximadamente $70 \%$ mais rica em $\mathrm{K}$ do que o grão,

A adubação nitrogenada diminuiu o teor de $P$ na polpa. 0 $P$ agiu favoravelmente sobre 0 teor de $K$ no grão. A adubação potássica 
aumentou o teor de $\mathrm{N}$ no grão enquanto a fosfatada elevou na polpa.

AMORIN et alii (1973), constataram que o excesso de $K$ na adubação reduziu o teor de B e $Z n$ no grão.

SILVA E SOUZA et alii (1975), concluîram que os teores de Ca e $P$ cairam sensivelmente nos frutos em desenvolvimento, atē atingirem niveis relativamente constantes a partir do mês de dezembro. $\mathrm{Na}$ folha, o teor de $\mathrm{Ca}$ aumentou de outubro para abril. Os teores foliares de $\mathrm{K}$ decresceram ligeiramente durante todo o perīodo de expansão dos frutos, sendo que nestes o decréscimo foi mais acentuado, o nível de $\mathrm{Mg}$ e $\mathrm{Mn}$ subiram nas folhas, na estação de crescimento e expansão dos frutos, sugerindo acúmulo contĩnuo nesses órgãos. Nos frutos o teor de Mg caiu com seu crescimento e o de Mn manteve-se relativamente estável. Os teores de $\mathrm{Zn}$ apresentaram um máximo em fins de dezembro e os teores de $\mathrm{Fe}$ foram desuniformes durante todo o periodo de estudo, sugerindo, todavia uma tendência a constância.

Alguns trabalhos foram realizados no sentido de se estudar a qualidade da bebida em função da composição do grão de café. Assim, AMORIN (1965), obteve resultados de degustação que parecem indicar o efeito favorável do $P$ na qualidade da bebida.

Jā o Nitrogēnio e Potāssio, segundo AMORIN et alii (1967), propiciaram bebida de qualidade um pouco inferior. A matéria orgânica não teve efeito significativo sobre a qualidade da bebida.

AMORIN (1973), encontrou correlação significativamente ne gativa entre 0 teor de $\mathrm{N}$ na semente e a qualidade da bebida. Concluiu 0 
autor, porēm, que o aumento na produção obtido com $\mathrm{N}$ e $\mathrm{K}$, compensa economicamente uma pequena perda na qualidade da bebida.

\subsection{Diagnose Foliar}

Conforme relatado anteriormente, somente com Liebig(1840), citado por MALAVOLTA et alii (1967), iniciou-se a aplicação quîmica na agricultura.

Weinhold (1862), citado por HIROCE (1981), relatou a idéia do uso da anāilise quîmica da planta como um indice de disponibilidade de nutrientes do solo.

Os fundamentos da diagnose foliar foram lançados por LAGATU e MAUME $(1926,1930)$, que estabeleceram o conceito de diagnose foliar como sendo o estado químico de uma folha, tomada em determinado momento.

Uma das relações mais importantes na anālise de planta pa ra fins de diagnóstico nutricional è a que envolve a produção, a concentração de nutrientes na planta e o nível de elemento no solo (MUNSON e NELSON, 1973).

MACY (1936), estabeleceu o conceito do nível crítico ou concentração ōtima de nutrientes na planta atravēs de relação entre o teor percentual do nutriente na folha e a produção final da planta. 0 nível crîtico ficou sendo o ponto de inflexão superior na curva produção $x$ teor de nutriente. Este nível crītico foi denominado por LOTT et alii (1961) de nīvel limiar, isto é, teor abaixo do qual o crescimento e 
produção seriam limitados e acima do qual não haveria crescimento nem aumento de produção.

CHAPMAN (1967), apresentou um tipo de curva mais ajustada para a relação concentração $x$ crescimento, onde evidencia o efeito de di luição sobre a concentração de nutrientes em determinado órgão da planta. Este aspecto ressalta a importāncia da escolha certa para a amostra gem, em relação à idade fisiológica do órgão amostrado.

Este aspecto da diluição foi extensivamente estudado por alguns autores, entre eles STEENBJERG (1951); STEENBJERG e JAKOBSEN (1963) e BATES (1971), etc. Em todos os trabalhos evidenciou-se que a percentagem de determinado nutriente em qualquer parte da planta, depende da época de amostragem.

Com relação ao cafeeiro, somente a partir da década de 1950, o emprego da análise quỉmica das folhas tomou impulso. LOUE (1951), na Africa; COOIL (1954), no Hawaii; CHAVERRI (1955), na Costa Rica; LOTT et alii (1956) e MALAVOLTA et alii (1958), no Brasil, ESPINOSA (1960), em El Salvador, etc.

0 teor de nutrientes nas folhas não ē apenas função da fertilidade do solo ou doses de adubos utilizados, mas também da idade da folha e da planta, época de amostragem, clima, tratos culturais. etc, Assim CHAVERRI et alii (1957), na Costa Rica, estudaram as variações mensais de macronutrientes, boro e manganês nas folhas do 40 par em cafeeiro arabica e observaram maior concentração de N, P e B nas folhas no periodo de maior quantidade de chuvas. 
LOUE (1958), utilizando o 30 par de folhas de cafeeiros robusta, verificou que maior teor de $\mathrm{N}$ foi encontrado na época de māxima vegetação.

OMATOSO e ALOJOLA (1972), estudando a composição de macronutrientes nas folhas de Coffea canephona Pierre durante seu ciclo, verificou variação no teor foliar.

Em relação a idade da folha, MULLER (1959) trabalhando com cafeeiro arabica verificou uma variação na composição foliar durante o processo de envelhecimento da folha.

Por outro lado, HUERTAS (1963), concluiu que a anālise do 40 par de folhas é mais indicado para se estudar o estado nutricional do cafeeiro.

Já COLONNA (1964), recomenda a amostragem do 30 par de fọ Thas em ramos localizados na altura média da planta.

Quanto a época de amostragem, ARISTIZABAL e POLGARIN(1977), verificaram para o cafeeiro, um perīodo ótimo para diagnose foliar, entre 4 e 6 meses antes da colheita.

Com relação à produção, ESPINOSA (1969), encontrou correlação positiva entre adubação, teores foliares de $\mathrm{N}$ e produtividade de cafeeiros jovens.

RAJU e SUBRA MANIAN (1969), observaram em cafeeiros da variedade "Kents" que as concentrações de $\mathrm{N}$ e $\mathrm{P}$ nas folhas (durante 0 desenvolvimento dos frutos), correlacionaram significativamente com as subsequentes produções. 
Por outro lado, VERLIERE (1973c), concluiu atravēs do diagnōstico foliar que a produção de café está mais nitidamente relacionada com os niveis foliares de cations do que de anions.

Jā no Brasil, MEDCALF et alii (1955), foram os primeiros a estudar sobre o emprego da anālise química foliar em cafeeiro arabica, fazendo determinações mensais de elementos nas folhas e encontrando teores de nitrogēnio, fósforo e potāssio mais baixos em abril (desenvolvimento dos frutos) e mais elevados em novembro (inĩcio de formação dos frutos).

SILVA e SILVA (1957), encontraram resultados semelhantes aos obtidos por MEDCALF et alii (1955), com inclusão do Mg.

Com relação à localização da folha no ramo, pesquisadores do IRI do Brasil escolheram independentemente a 3a. folha (LOTT et alii, 1956)

Alguns pesquisadores, passaram a utilizar o 30 par de foIhas, a partir de então (GALLO et alii, 1967 e HIROCE et alii, 1972). No entanto, MALAVOLTA et alii (1964), não encontraram diferenças significativas nos teores de $\mathrm{N}, \mathrm{K}, \mathrm{Ca}, \mathrm{Mg}$ e $\mathrm{S}$ do $10,20,30$ e 40 par de folhas, recomendando dessa forma o 30 ou 40 par para uso em diagnose foliar. 
3. MATERIAL E METODOS

\subsection{Localidade.}

Foi utilizado para este trabalho um talhão de cafeeiros cv. Catuaĩ (H 2077-2-5-39) espaçado de 4,0m $\times 2,5 \mathrm{~m}$, com 5 anos de idade, 2 plantas por cova, situado em um latossolo Roxo distrófico do centro experimental do IAPAR em Londrina-PR.

Utilizou-se o delineamento experimental inteiramente casualizado com 6 repetições sendo cada parcela representada por uma cova de 2 plantas. A regressão escolhida foi a de maior grau significativo atē $3 \stackrel{\text { grau. }}{\text { gra }}$

Os resultados das anālises granulométrica e quîmica para fins de fertilidade do solo em que foi instalado o experimento, são apre sentados na Tabela 1. 


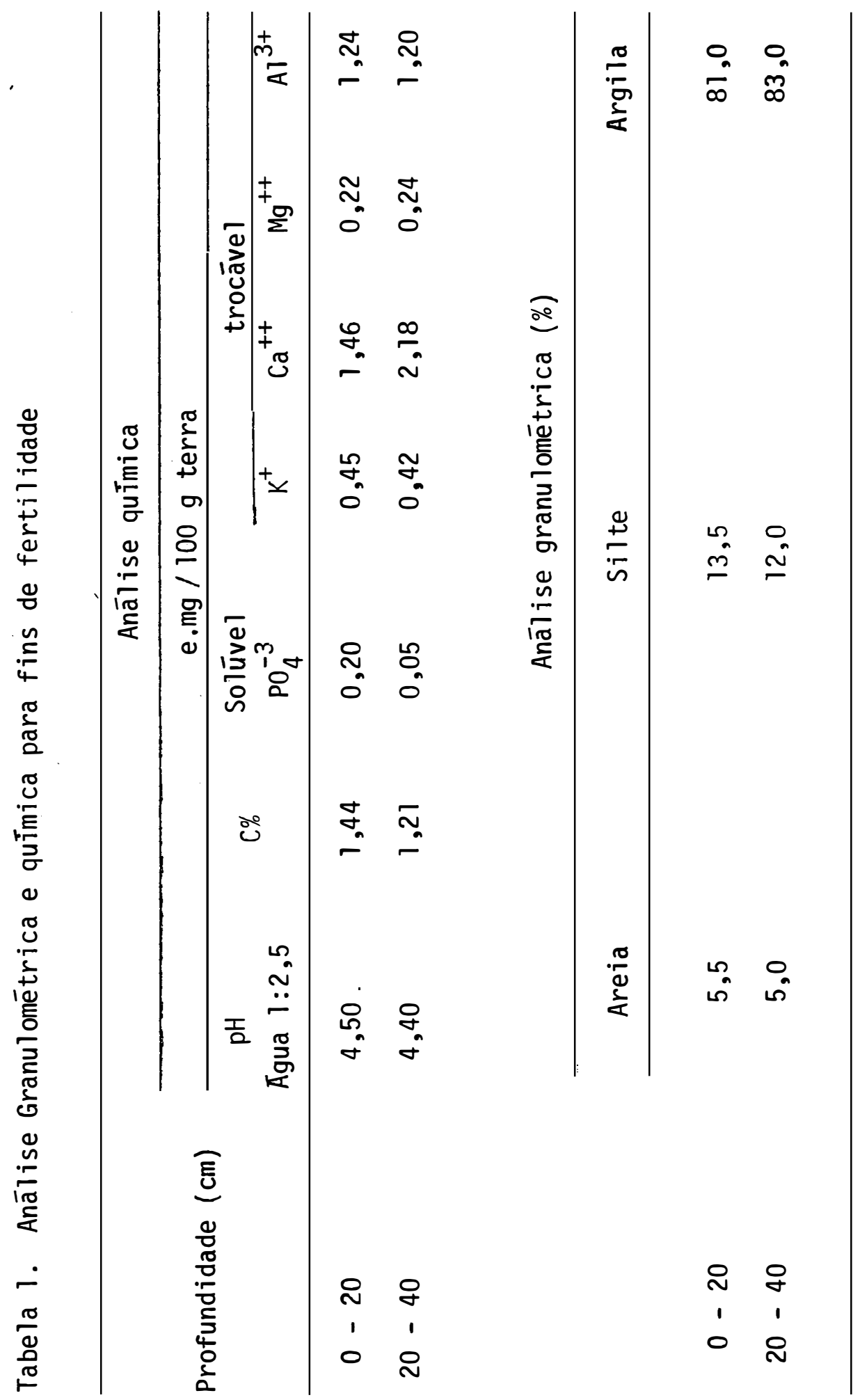


As anālises granulomëtrica e quīmica foram realizadas pe1o Laboratōrio de Solos do Instituto Agronōmico do Paranā - IAPAR.

A anālise granulométrica foi efetuada pelo método de MEDINA E GROHMANN (1962).

As anālises quỉmicas foram realizadas segundo os métodos descritos por VAN RAIJ (1977).

Esta ārea recebeu adubação uniforme, segundo o esquema apresentado na Tabela 2.

Tabela 2. Adubação dos Cafeeiros

\begin{tabular}{lcc}
\hline Adubo & $\begin{array}{c}\text { Quantidade } \\
\text { elemento (g/cova/ano) }\end{array}$ & $\begin{array}{c}\text { Nọ de } \\
\text { aplicações }\end{array}$ \\
\hline Sulfato Amônio & $120 \mathrm{~N}$ & 4 \\
Superfosfato Simples & $25 \mathrm{P}_{2} \mathrm{O}_{5}$ & 1 \\
Cloreto de Potássio & $60 \mathrm{~K}_{2} \mathrm{O}$ & 2 \\
\hline
\end{tabular}

As informações relativas à distribuição das chuvas durante o perỉodo do experimento e a temperatura média são mostrados na Tabela 3 . 
Tabela 3. Dados termopluviométricos diārios do Centro Experimental do IAPAR - Londrina-PR, no periodo de dezembro/80 a agosto/81,

\begin{tabular}{|c|c|c|c|c|c|c|c|c|c|}
\hline \multicolumn{10}{|c|}{ Médias de Temperaturas Diārias $\left({ }^{\circ} \mathrm{C}\right)$} \\
\hline Dia & $12 / 80$ & $01 / 81$ & $02 / 81$ & $03 / 81$ & $04 / 81$ & $05 / 81$ & $06 / 81$ & $07 / 81$ & $08 / 81$ \\
\hline $\begin{array}{l}01 \\
02 \\
03 \\
04 \\
05 \\
06 \\
07 \\
08 \\
09 \\
10 \\
11 \\
12 \\
13 \\
14 \\
15 \\
16 \\
17 \\
18 \\
19 \\
20 \\
21 \\
22 \\
23 \\
24 \\
25 \\
26 \\
27 \\
28 \\
29 \\
30 \\
31\end{array}$ & $\begin{array}{l}23,3 \\
22,7 \\
22,0 \\
23,5 \\
23,9 \\
25,3 \\
25,6 \\
24,9 \\
25,3 \\
24,7 \\
22,4 \\
22,3 \\
23,9 \\
24,9 \\
23,6 \\
25,2 \\
26,4 \\
23,3 \\
22,1 \\
22,2 \\
21,4 \\
21,1 \\
22,1 \\
24,0 \\
24,2 \\
23,6 \\
21,1 \\
22,4 \\
24,8 \\
26,0 \\
23,7\end{array}$ & $\begin{array}{l}24,3 \\
23,7 \\
23,5 \\
23,5 \\
23,6 \\
23,0 \\
22,8 \\
22,6 \\
22,4 \\
24,4 \\
22,6 \\
23,1 \\
21,9 \\
23,5 \\
23,2 \\
23,8 \\
24,2 \\
23,8 \\
23,5 \\
24,8 \\
22,3 \\
21,4 \\
23,1 \\
23,9 \\
23,7 \\
22,7 \\
24,2 \\
25,0 \\
25,2 \\
24,2 \\
24,5\end{array}$ & $\begin{array}{l}25,9 \\
26,1 \\
25,4 \\
24,0 \\
23,7 \\
23,6 \\
24,0 \\
24,9 \\
24,3 \\
23,9 \\
23,8 \\
23,7 \\
24,6 \\
25,6 \\
26,4 \\
25,9 \\
24,6 \\
25,4 \\
23,1 \\
21,2 \\
19,9 \\
21,2 \\
23,0 \\
23,7 \\
22,7 \\
23,9 \\
25,6 \\
25,8\end{array}$ & $\begin{array}{l}26,2 \\
26,3 \\
25,3 \\
23,5 \\
22,3 \\
23,4 \\
24,1 \\
24,4 \\
23,8 \\
24,5 \\
25,3 \\
24,6 \\
25,2 \\
25,9 \\
25,2 \\
21,5 \\
23,6 \\
22,9 \\
23,1 \\
22,9 \\
23,2 \\
21,6 \\
22,4 \\
22,1 \\
23,0 \\
24,7 \\
22,7 \\
20,4 \\
22,7 \\
22,2 \\
21,1\end{array}$ & $\begin{array}{l}22,7 \\
22,0 \\
22,3 \\
23,7 \\
23,4 \\
24,2 \\
24,3 \\
23,8 \\
22,1 \\
20,5 \\
19,8 \\
21,2 \\
21,6 \\
22,8 \\
21,0 \\
19,7 \\
19,1 \\
17,3 \\
17,5 \\
19,8 \\
21,1 \\
22,0 \\
19,0 \\
20,1 \\
19,5 \\
18,9 \\
18,1 \\
19,5 \\
16,1 \\
15,9\end{array}$ & $\begin{array}{l}16,5 \\
17,5 \\
19,6 \\
21,3 \\
21,6 \\
22,4 \\
21,9 \\
20,7 \\
20,7 \\
21,0 \\
21,6 \\
21,7 \\
22,1 \\
21,1 \\
19,8 \\
18,0 \\
19,3 \\
20,3 \\
20,5 \\
21,4 \\
21,0 \\
20,6 \\
19,8 \\
20,0 \\
18,8 \\
19,5 \\
19,0 \\
17,9 \\
16,8 \\
17,6 \\
17,9\end{array}$ & $\begin{array}{r}19,0 \\
21,5 \\
18,3 \\
17,5 \\
17,3 \\
15,7 \\
12,4 \\
12,3 \\
12,3 \\
15,1 \\
17,5 \\
17,4 \\
16,6 \\
18,1 \\
15,5 \\
15,1 \\
8,8 \\
6,3 \\
7,5 \\
11,9 \\
14,0 \\
16,7 \\
17,3 \\
18,4 \\
18,0 \\
17,6 \\
17,7 \\
17,4 \\
18,8 \\
19,9\end{array}$ & $\begin{array}{r}19,8 \\
17,4 \\
13,5 \\
12,8 \\
14,2 \\
14,0 \\
14,6 \\
15,8 \\
15,4 \\
16,1 \\
17,6 \\
17,2 \\
18,0 \\
19,1 \\
20,3 \\
20,9 \\
14,4 \\
8,7 \\
6,9 \\
4,5 \\
9,6 \\
12,2 \\
14,4 \\
10,6 \\
10,1 \\
13,7 \\
15,7 \\
16,4 \\
17,5 \\
19,7 \\
18,4\end{array}$ & $\begin{array}{l}18,9 \\
19,0 \\
19,8 \\
20,8 \\
20,9 \\
20,1 \\
22,1 \\
18,9 \\
15,1 \\
15,8 \\
16,6 \\
21,2 \\
21,7 \\
17,6 \\
18,3 \\
19,0 \\
15,4 \\
17,1 \\
17,6 \\
15,6 \\
16,2 \\
17,0 \\
18,2 \\
20,1 \\
21,8 \\
22,7 \\
23,8 \\
21,7 \\
21,8 \\
21,8 \\
17,9\end{array}$ \\
\hline & 23,6 & 23,5 & 24,1 & 23,6 & 20,6 & 19,9 & 15,7 & 14,8 & 19,2 \\
\hline
\end{tabular}

Dados fornecidos pela ārea de Agrometeorologia do Centro Experimental do IAPAR. 
Tabela 3. Continuação

\section{Precipitação Diāria (mm)}

\begin{tabular}{|c|c|c|c|c|c|c|c|c|c|}
\hline Dia & $12 / 80$ & $01 / 80$ & $02 / 81$ & $03 / 81$ & $04 / 81$ & $05 / 81$ & $06 / 81$ & $07 / 81$ & $08 / 81$ \\
\hline $\begin{array}{l}01 \\
02 \\
03 \\
04 \\
05 \\
06 \\
07 \\
08 \\
09 \\
10 \\
11 \\
12 \\
13 \\
14 \\
15 \\
16 \\
17 \\
18 \\
19 \\
20 \\
21 \\
22 \\
23 \\
24 \\
25 \\
26 \\
27 \\
28 \\
29 \\
30 \\
31\end{array}$ & $\begin{array}{r}0,0 \\
10,0 \\
7,6 \\
9,3 \\
6,0 \\
0,0 \\
0,0 \\
0,0 \\
0,0 \\
0,0 \\
32,2 \\
18,0 \\
12,0 \\
8,0 \\
0,0 \\
0,0 \\
0,0 \\
0,0 \\
68,4 \\
1,0 \\
31,8 \\
30,4 \\
2,6 \\
0,8 \\
0,0 \\
0,0 \\
41,6 \\
21,0 \\
20,6 \\
0,0 \\
8,5\end{array}$ & $\begin{array}{r}0,0 \\
0,0 \\
0,0 \\
0,0 \\
16,4 \\
4,5 \\
7,2 \\
1,8 \\
48,0 \\
1,0 \\
0,0 \\
2,5 \\
20,0 \\
18,0 \\
9,2 \\
3,8 \\
0,0 \\
6,0 \\
9,0 \\
0,4 \\
41,0 \\
4,4 \\
3,8 \\
0,0 \\
0,0 \\
0,8 \\
0,4 \\
0,0 \\
0,0 \\
0,0 \\
25,0\end{array}$ & $\begin{array}{r}0,0 \\
0,0 \\
0,0 \\
25,0 \\
8,4 \\
7,0 \\
0,0 \\
0,0 \\
0,0 \\
0,0 \\
0,0 \\
4,0 \\
50,0 \\
6,6 \\
0,0 \\
0,0 \\
0,0 \\
0,0 \\
0,0 \\
26,4 \\
1,4 \\
3,0 \\
21,6 \\
0,0 \\
1,6 \\
0,4 \\
0,0 \\
0,0\end{array}$ & $\begin{array}{r}0,0 \\
0,0 \\
0,0 \\
23,4 \\
0,4 \\
0,0 \\
0,4 \\
0,0 \\
0,0 \\
0,0 \\
0,0 \\
0,0 \\
0,0 \\
0,0 \\
4,0 \\
0,0 \\
38,4 \\
0,0 \\
0,0 \\
0,0 \\
0,0 \\
0,0 \\
0,0 \\
0,0 \\
0,0 \\
0,0 \\
0,0 \\
1,0 \\
1,0 \\
0,0 \\
0,0\end{array}$ & $\begin{array}{r}0,0 \\
0,0 \\
0,0 \\
0,0 \\
0,0 \\
1,0 \\
0,0 \\
0,0 \\
0,0 \\
0,0 \\
0,0 \\
0,0 \\
0,0 \\
0,0 \\
0,0 \\
11,0 \\
0,4 \\
0,0 \\
0,0 \\
0,0 \\
0,0 \\
0,0 \\
19,0 \\
9,1 \\
0,0 \\
1,2 \\
49,2 \\
52,6 \\
0,8 \\
0,0\end{array}$ & $\begin{array}{l}0,0 \\
0,0 \\
1,2 \\
0,5 \\
0,0 \\
0,0 \\
0,0 \\
0,0 \\
0,0 \\
0,0 \\
0,0 \\
0,0 \\
0,0 \\
0,0 \\
0,0 \\
0,0 \\
0,0 \\
0,0 \\
0,0 \\
0,0 \\
0,0 \\
0,0 \\
0,0 \\
0,0 \\
0,0 \\
0,0 \\
0,0 \\
0,0 \\
0,0 \\
0,0 \\
0,0\end{array}$ & $\begin{array}{r}0,0 \\
0,0 \\
26,2 \\
0,0 \\
0,0 \\
12,3 \\
1,8 \\
0,8 \\
0,0 \\
0,0 \\
0,0 \\
0,0 \\
17,8 \\
0,0 \\
0,0 \\
52,0 \\
0,0 \\
0,0 \\
0,0 \\
1,3 \\
0,0 \\
0,0 \\
0,0 \\
0,3 \\
0,0 \\
0,0 \\
0,0 \\
0,0 \\
0,0 \\
0,0\end{array}$ & $\begin{array}{l}0,0 \\
17,3 \\
1,3 \\
0,0 \\
0,0 \\
0,0 \\
0,0 \\
0,0 \\
0,0 \\
0,0 \\
0,0 \\
0,0 \\
0,0 \\
0,0 \\
0,0 \\
0,0 \\
0,0 \\
1,0 \\
1,6 \\
0,0 \\
0,0 \\
0,0 \\
0,0 \\
0,0 \\
0,0 \\
0,0 \\
0,0 \\
0,0 \\
0,0 \\
0,0 \\
0,0\end{array}$ & $\begin{array}{l}0,0 \\
0,0 \\
0,0 \\
0,0 \\
0,0 \\
0,0 \\
0,0 \\
0,0 \\
3,0 \\
3,2 \\
0,0 \\
0,3 \\
0,0 \\
0,0 \\
0,0 \\
0,0 \\
0,5 \\
2,0 \\
0,0 \\
0,0 \\
0,0 \\
0,0 \\
0,0 \\
0,0 \\
0,0 \\
0,0 \\
0,0 \\
0,0 \\
0,0 \\
0,0 \\
0,0\end{array}$ \\
\hline & 329,8 & 223,2 & 155,4 & 69,2 & 144,3 & 1,7 & 112,5 & 21,8 & 9,0 \\
\hline
\end{tabular}


Esses dados mostram que ocorreram condições adequada.s para o bom desenvolvimento da cultura. A exceção do mês de maio, que choveu muito pouco, todos os outros meses apresentaram precipitações sa tisfatōrias alēm do que, bem distribuidas, principalmente, de dezembro a abril, que é justamente o perīodo de maior desenvolvimento do fruto e por conseguinte o de maior exigēncia em āgua.

\subsection{Coleta de Frutos e Folhas.}

Embora exista grande desuniformidade no tamanho dos frutos, devido às vārias floradas, fenōmeno perfeitamente caracterizado nas lavouras de café, as coletas foram iniciadas em meados de dezembro quando havia maior percentagem de frutos no estádio "chumbinho". A cada 21 dias a operação era repetida, conforme mostra a Tabela 4. (zero dias = aparecimento de "chumbinho"; 21 dias alta concentração de "chumbinho" nas plantas). Paralelamente às coletas dos frutos, foram realizadas amostragens de folhas.

Foram coletados todos os frutos da planta e conforme LOTT et alii (1956), amostras do 30 par de folhas. Foram amostrados 8 pares de folhas de ramos medianos ao redor de cada cova. Foram coletadas folhas de ramos com frutos e ramos sem frutos. 
Tabela 4. Epoca de amostragem de frutos e folhas

\begin{tabular}{|c|c|c|c|c|c|}
\hline Amostragem & Epoca* & Data & Frutos & $\begin{array}{c}\text { Folhas } \\
\text {. }\end{array}$ & 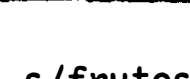 \\
\hline la. & 21 & 17.12 .80 & $"$ & $"$ & $"$ \\
\hline $2 a$. & 42 & 07.01 .01 & $"$ & $"$ & $"$ \\
\hline 3a. & 63 & 28.01 .81 & $"$ & $"$ & $"$ \\
\hline $4 a$. & 84 & 18.02 .81 & $"$ & $"$ & $"$ \\
\hline $5 a$. & 105 & 11.03 .81 & $"$ & $"$ & $"$ \\
\hline $6 a$. & 126 & 01.04 .81 & $"$ & $"$ & $"$ \\
\hline $7 a$. & 147 & 22.04 .81 & $"$ & $"$ & $"$ \\
\hline $8 a$. & 168 & 13.05 .81 & $"$ & $"$ & $"$ \\
\hline $9 a$. & 189 & 03.06 .81 & $"$ & $"$ & $"$ \\
\hline $10 a$. & 210 & 24.06 .81 & $"$ & $"$ & $"$ \\
\hline $11 a$. & 231 & 15.07 .81 & $"$ & $"$ & $"$ \\
\hline $12 a$. & 252 & 05.08 .81 & $"$ & $"$ & $"$ \\
\hline
\end{tabular}

* Dias apōs o início do aparecimento de "chumbinho".

\subsection{Preparo e Anālise das Amostras.}

Os frutos de cada cova foram pesados em sua totalidade e posteriormente uma amostra homogēnea foi extraida, retirando-se as impurezas (pedunculo, folha, etc.), novamente pesados e colocados em sacos plāsticos. 
As folhas foram colhidas, embaladas em sacos de papel previamente identificadas seguindo juntamente com os frutos para Laboratōrio, onde foram lavados em āgua desmineralizada e colocados a perder a umidade adquirida em temperatura ambiente. Posteriormente foram levados para secagem em estufa, mantida à temperatura de aproximadamente $70^{\circ} \mathrm{C}$ atē peso constante. Posteriormente as folhas e frutos foram moĩdos, conforme preconiza SARRUGE e HAAG (1974). O material foi colocado em sacos plāsticos identificados e aĩ armazenàdos atē a época da anālise quĩmica.

Nas amostras de frutos e folhas foram feitas determinações de nitrogēnio (N), fósforo (P), potāssio (K), cālcio (Ca), Magnēsio $(M g)$, enxofre $(S)$, zinco $(Z n)$, manganês $(M n)$, cobre $(C u)$ e boro (B), segundo os métodos descritos por SARRUGE e HAAG (1974). 
4. RESULTADOS E DISCUSSĀO

\subsection{Desenvolvimento dos Frutos.}

Foram utilizados os dados de produção de matéria seca, como indicador do desenvolvimento dos frutos do cafeeiro.

A Tabela 5 mostra os dados sobre o desenvolvimento dos frutos expresso pela acumulação de matéria seca, em função da época de amostragem.

A anālise da variāncia do acūmulo de matéria seca pelos frutos, acha-se na Tabela 6.

Houve um acúmulo de matéria seca pelos frutos do cafeeiro (Coffea arabica L., cv. Catuaî), traduzido por uma regressão quadrātica, conforme mostra a Figura 1, com ponto de máximo aos 217 dias apōs o início do aparecimento de "chumbinho" com 4.251,46 g/cova.

0 desenvolvimento dos frutos foi muito acentuado dos 21 aos 168 dias, sendo mais lento apōs este perīodo. 
Tabela 5. Acúmulo de matéria seca pelos frutos de uma cova de cafeeiros (2 plantas), em função do seu desenvolvimento (média de 06 repetições)

\begin{tabular}{|c|c|}
\hline Epoca* & Matēria Seca ( $g /$ cova) \\
\hline 21 & 294,15 \\
\hline 42 & 725,53 \\
\hline 63 & $1.740,96$ \\
\hline 84 & $2.201,71$ \\
\hline 105 & $2.347,55$ \\
\hline 126 & $3.080,40$ \\
\hline 147 & $3.800,40$ \\
\hline 168 & $4.516,88$ \\
\hline 189 & $4.587,84$ \\
\hline 210 & $4.570,20$ \\
\hline 231 & $3.348,75$ \\
\hline 252 & $4.290,95$ \\
\hline d.m.s. (Tukey a 5\%) & $1.546,60$ \\
\hline
\end{tabular}




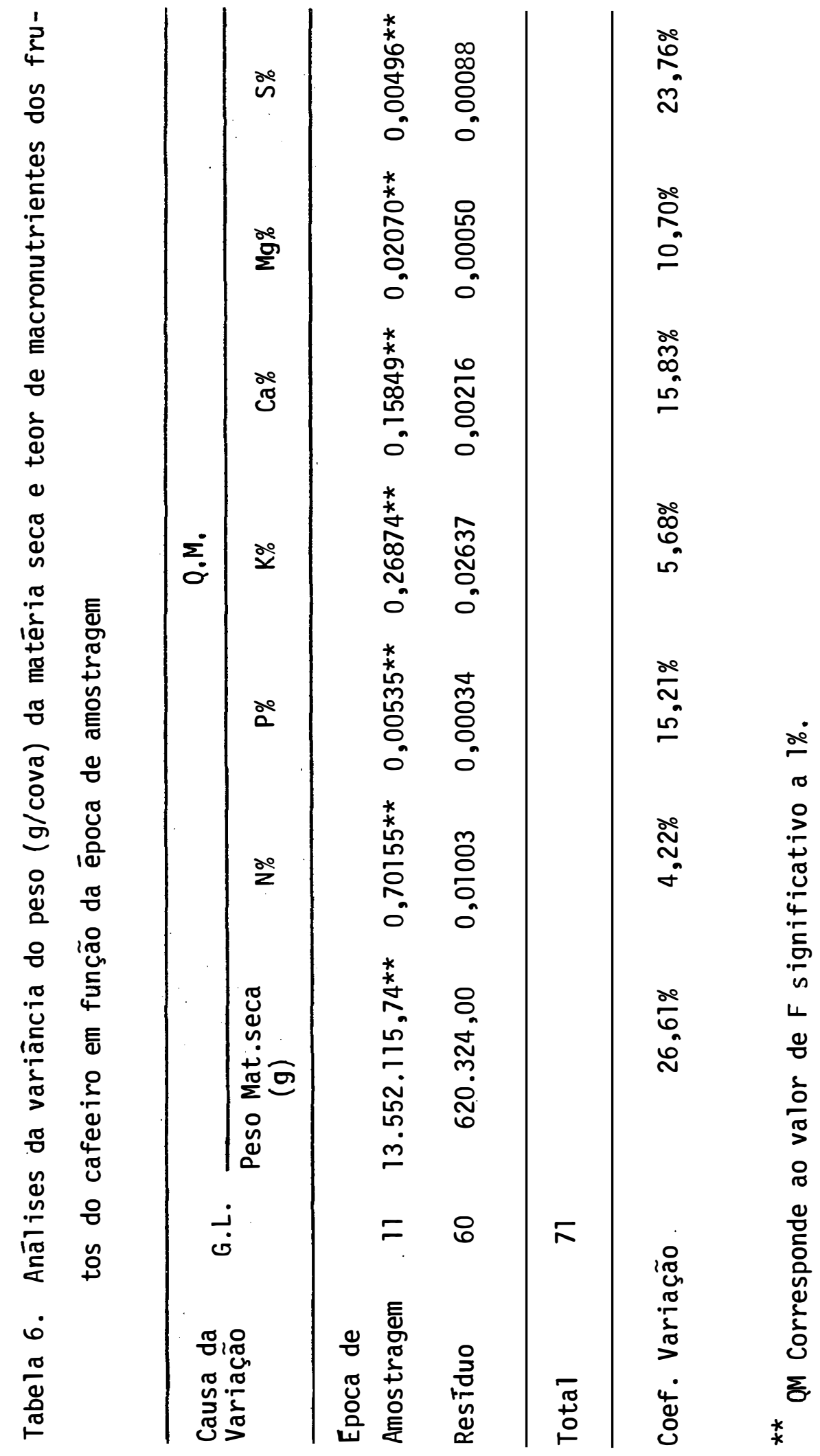




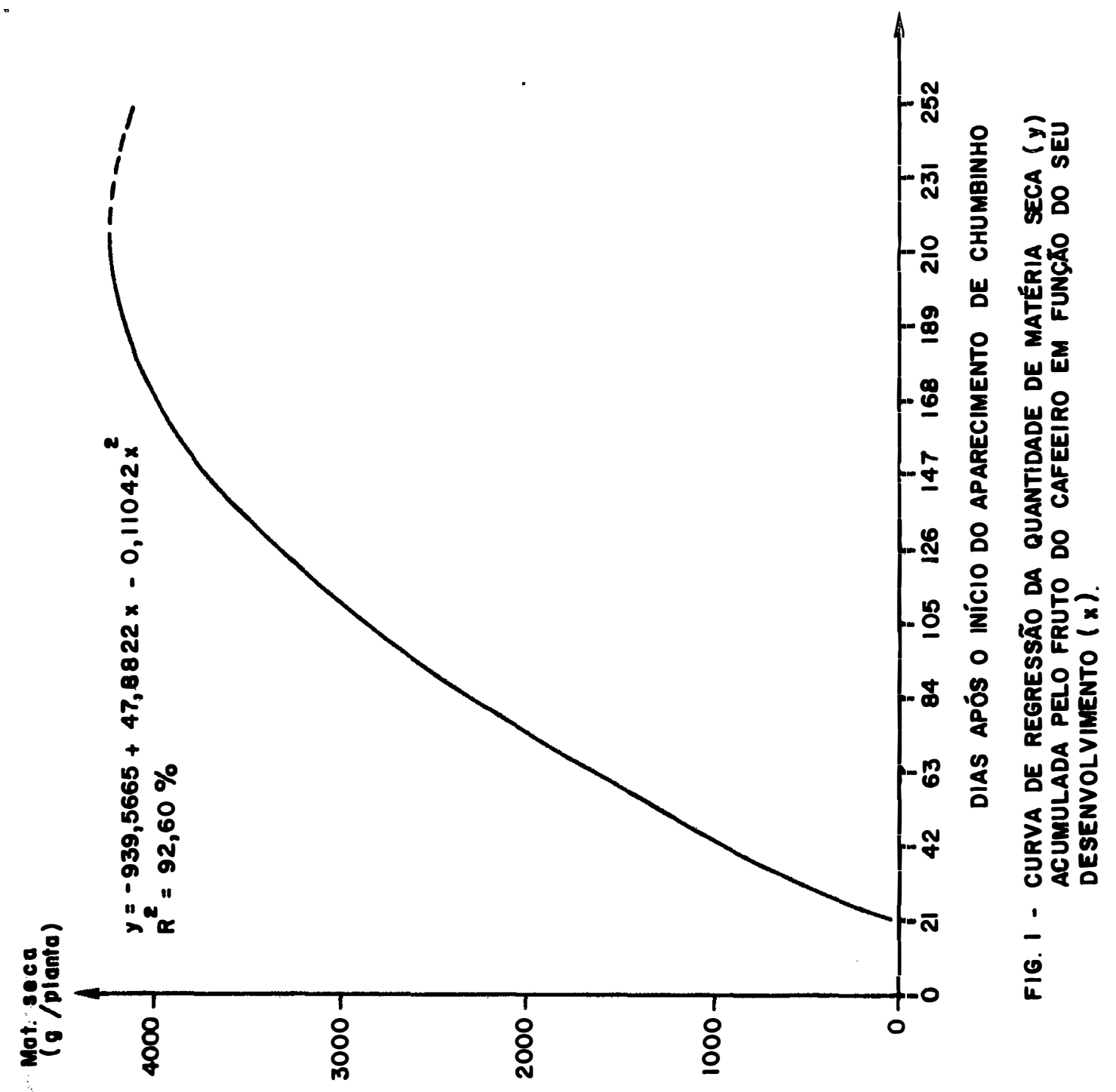


CATANI et alii (1967b) trabalhando com Cofbea aräbica L., var. Bourbon Vermelho, observaram uma acumulação de matéria seca nos frutos atē aos 180 dias, a partir do inīcio da formação dos mesmos.

Na Nigēria, OYEBADE (1976), com Coffea conephora, verificou acumulação de matēria seca nos frutos atē 26 semanas (182 dias) a partir do estādio "chumbinho".

\subsection{Nitrogênio}

\subsubsection{Concentração ${ }^{1}$}

Os valores da concentração de Nitrogēnio dos frutos, das folhas de ramos com frutos e das folhas de ramos sem frutos, em função da época de amostragem, acham-se na Tabela 7.

A anālise da variāncia da concentração de nitrogênio dos frutos, em função do seu desenvolvimento encontra-se exposta na Tabe la 6 , verificando-se que houve efeito de época.

Aos teores de nitrogēnio dos frutos, ajustou-se uma equa ção de regressão cúbica, conforme é mostrada na Figura 2, sendo que as concentrações diminuiram de 3,18\% para $2,02 \%$ dos 21 aos 252 dias apōs o inīcio do aparecimento de "chumbinho". 0 ponto de inflexão se situou aos 166 dias com teor de 2,22\%.

1 Valores da concentração expresso em função da matéria seca. 
Tabela 7. Concentração (\%) de nitrogēnio dos frutos, das folhas de ramos com frutos e das folhas de ramos sem frutos, em função da ēpoca de amostragem (mēdia de 6 repetições)

\begin{tabular}{|c|c|c|c|c|}
\hline \multirow{2}{*}{ Epoca* } & \multirow{2}{*}{ Frutos } & \multicolumn{3}{|c|}{ Folha } \\
\hline & & Ramos com frutos & Ramos & sem frutos \\
\hline 21 & 3,33 & 3,01 & & 2,76 \\
\hline 42 & 2,58 & 3,10 & & 3,07 \\
\hline 63 & 2,52 & 2,97 & & 2,93 \\
\hline 84 & 2,42 & 2,86 & & 2,95 \\
\hline 105 & 2,32 & 2,79 & & 2,98 \\
\hline 126 & 2,32 & 2,90 & & 3,01 \\
\hline 147 & 2,27 & 2,88 & & 2,99 \\
\hline 168 & 2,23 & 2,88 & & 3,00 \\
\hline 189 & 2,12 & 2,63 & & 2,95 \\
\hline 210 & 2,17 & 2,52 & & 2,72 \\
\hline 231 & 2,10 & 2,82 & & 2,88 \\
\hline 252 & 2,08 & 2,81 & & 3,03 \\
\hline d.m.s. (Tukey 5\%) & 0,20 & 0,29 & & 0,29 \\
\hline
\end{tabular}




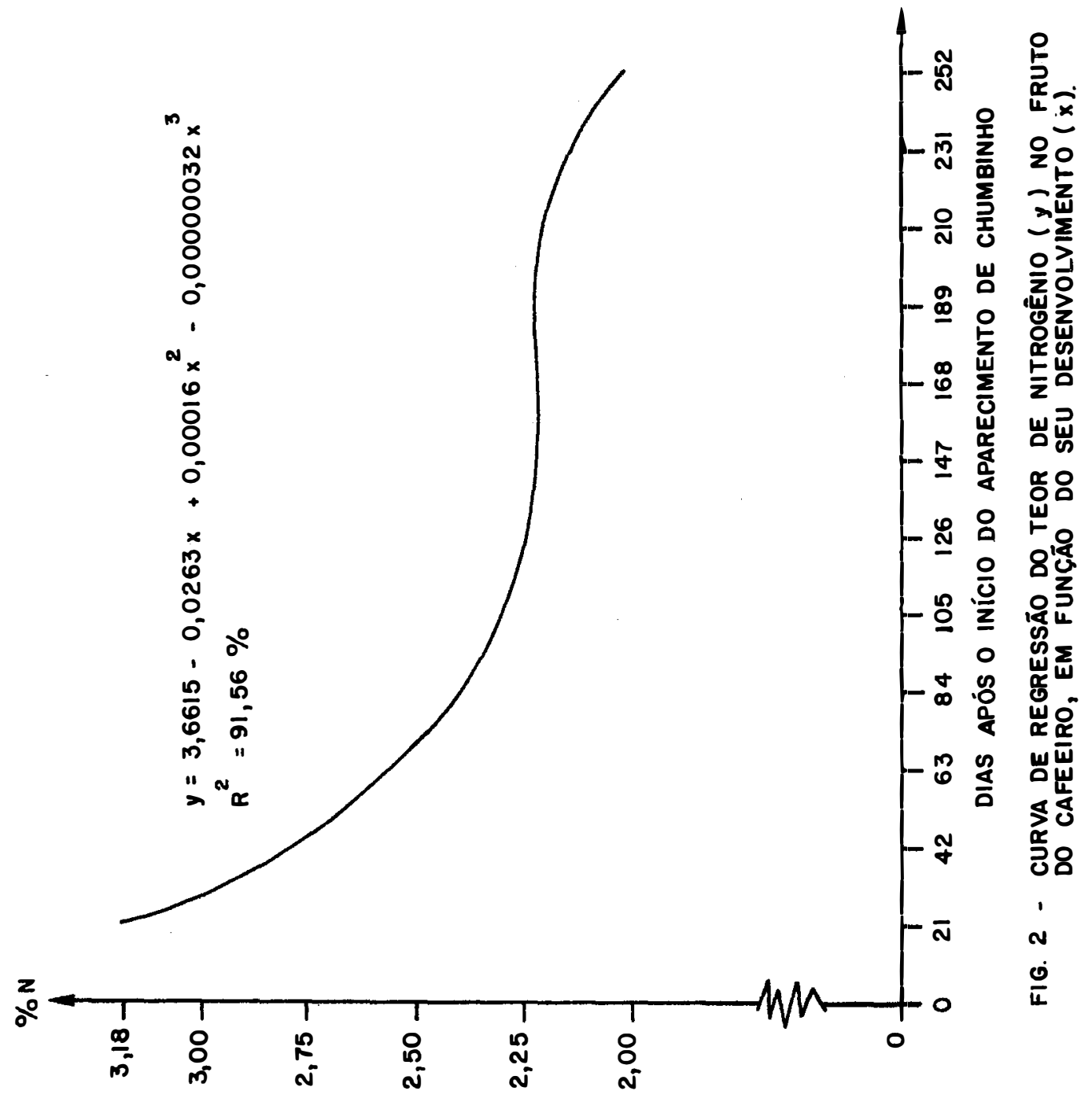


Houve redução do teor de $\mathrm{N}$ dos frutos em função da época de amostragem, sendo essa redução acentuada até aos 126 dias, perīodo esse que coincidiu com o maior desenvolvimento dos mesmos.

CATANI e MORAES (1958), analisando frutos do cafeeiro no inĩcio de sua formação e na maturação, verificaram que no inīcio de formação, os teores de nitrogênio foram mais elevados.

MORAES e CATANI (1964), estudando a absorção de elementos minerais pelos frutos do cafeeiro, durante sua formação, verificaram que o teor de nitrogênio foi mais elevado no estādio "chumbinho" $(N=1,75 \%)$ e mais baixo com os frutos no estádio "cereja" $(N=1,71 \%)$.

CATANI et alii (1967b), verificando a variação na concentração de macro e micronutrientes dos frutos do cafeeiro, durante o seu desenvolvimento, constataram que o teor de $\mathrm{N}$ diminuiu de $2,64 \%$ na fase de inīcio de formação atē $1,53 \%$ na fase de maturação.

Com relação às folhas, a anālise da variância da concentração de nitrogênio das folhas de ramos com frutos e das folthas de ramos sem frutos, em função da época de amostragem, pode ser vista na Tabela 8. A concentração de nitrogênio foi afetada pela época e tipo de folha, com interação.

Os teores de nitrogênio das folhas de ramos com frutos, diminuiram com a época de amostragem, segundo uma equação de regressão quadrātica, mostrada na Figura 3, sendo que nas concentrações estimadas os valores diminuiram de $3,08 \%$ para um minnimo de $2,73 \%$ dos 21 aos 233 dias apōs o inīcio do aparecimento de "chumbinho". 


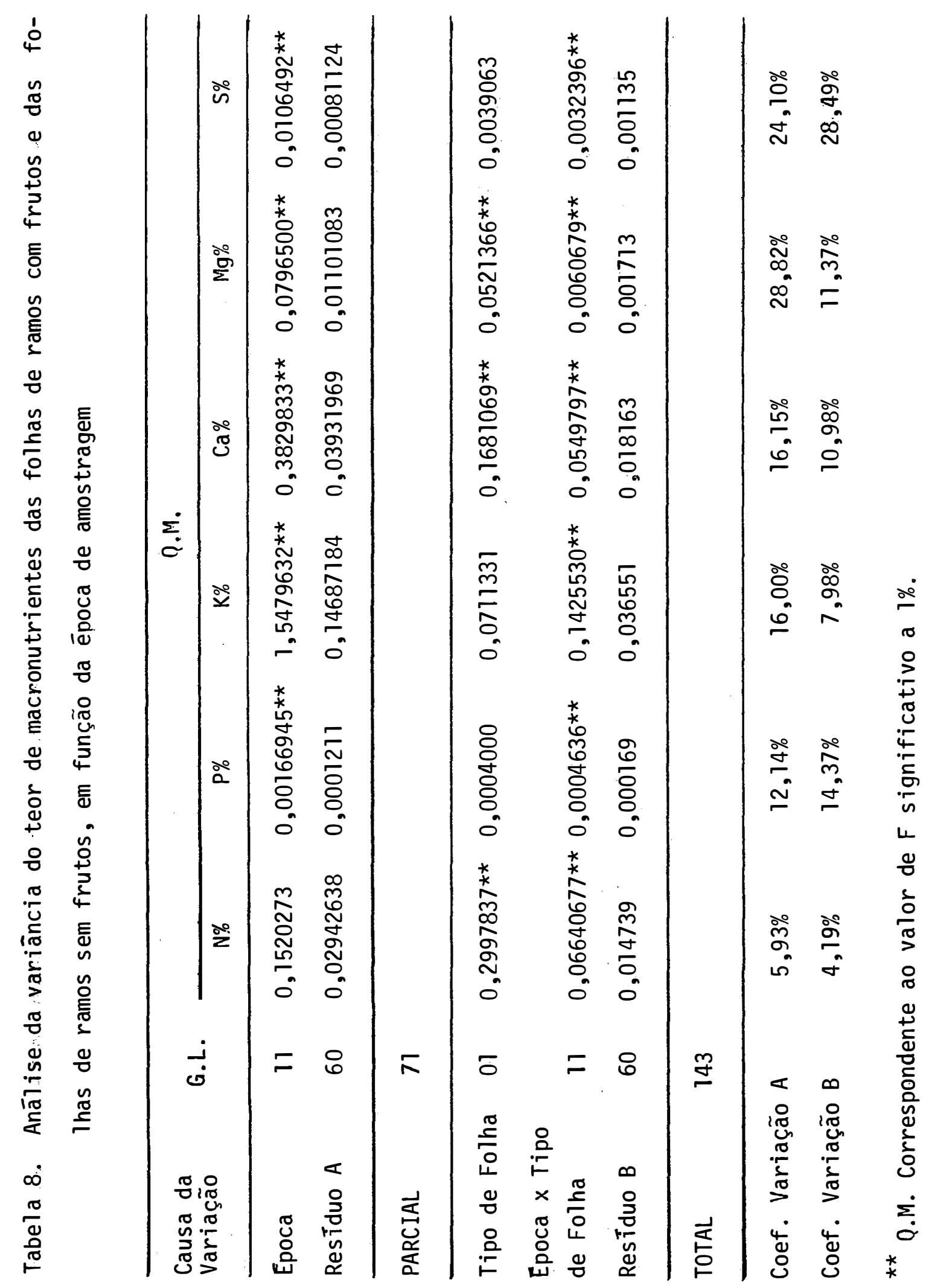




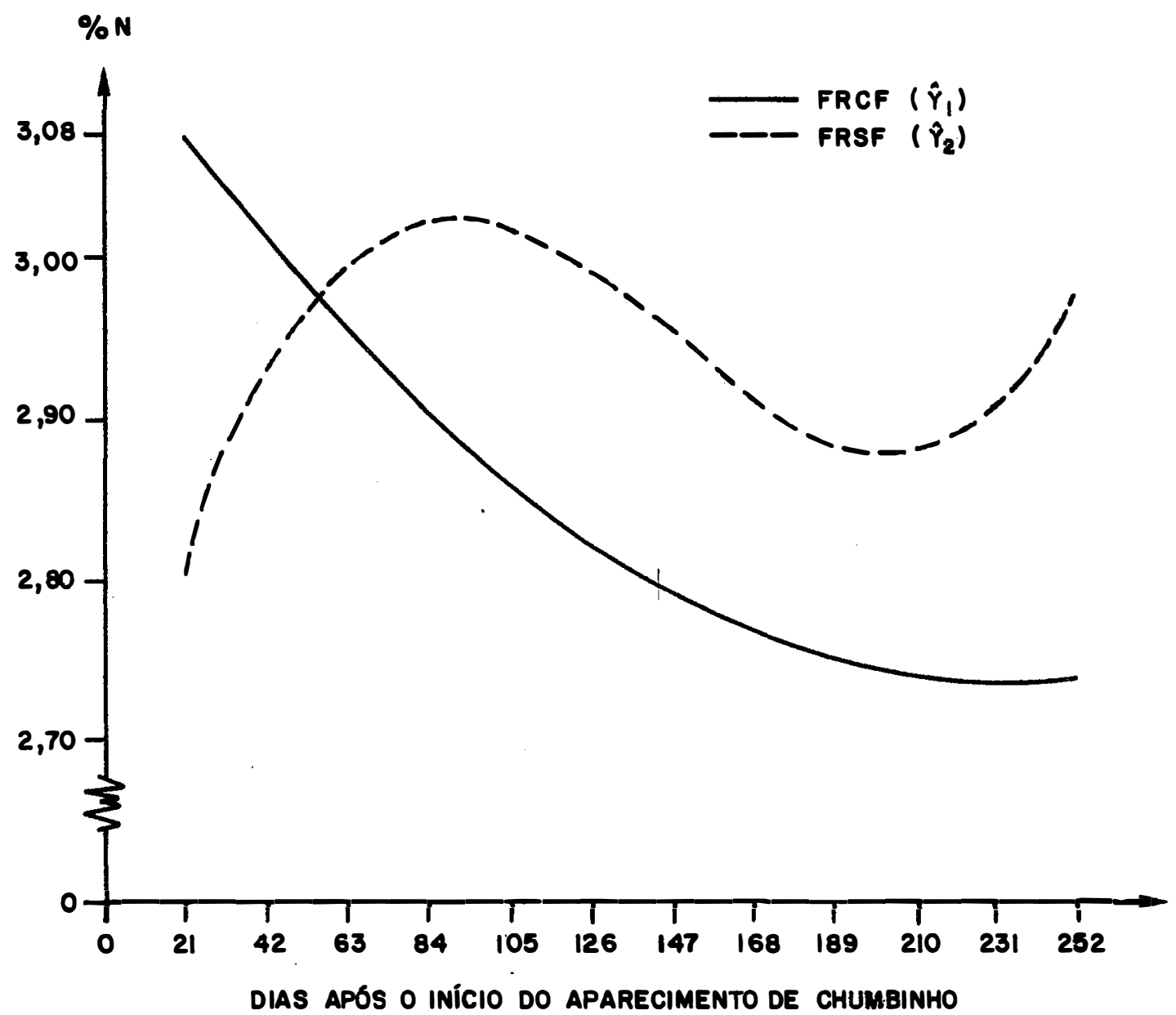

$\hat{Y}_{1}=3,1530-0,003581 x+0,00000769 x^{2} \quad\left(R^{2}=55,97 \%\right)$

$\hat{Y}_{2}=2,6141+0 ; 01069 x-0,00008578 x^{2}+0,000000195 x^{3} \quad\left(R^{2}=37,48 \%\right)$

FIG. 3 - CURVAS DE REGRESSÃO DOS TEORES DE NITROGÊNIO (y) EM FOLHA DE RAMOS COM FRUTOS (-) E FOLHA DE RAMOS SEM FRUTOS(-

EM FUNCÃo. DA ÉPOCA DE AMOSTRAGEM $(x)$. 
Nas folhas de ramos sem frutos, aos teores de nitrogēnio ajustou-se uma equação de regressão cúbica, conforme Figura 3, sendo que o teor aumentou de $2,80 \%$ para um máximo de 3,02\% dos 21 aos 90 dias apōs o iñ̄cio do aparecimento de "chumbinho". Apōs esse perīodo a concentração diminuiu atē $2,88 \%$ aos 204 dias sendo o ponto de inflexão aos 147 dias com $2,95 \%$.

Embora a variação da concentração de nitrogēnio nos dois tipos de folhas tenha sido distinta ao longo do desenvolvimento dos fru tos, em média, o teor de nitrogênio foi mais elevado nas folhas de ramos sem frutos.

Nasfolhas de ramos com produção, os teores de nitrogēnio foram mais elevados no estádio inicial de crescimento dos frutos, sendo que a concentração baixou de forma mais acentuada atē aos 168 dias, provavelmente o-orrendo neste perīodo maior redistribuição do elemento.

Jā nas folhas de ramos sem produção, os teores de nitrogênio foram mais baixos no inīcio de crescimento dos frutos, aumentando atē aos 90 dias. Após este período, a concentração do elemento começou baixar seguindo esta tendência até aos 204 dias, sugerindo a ocor rência tambēm neste tipo de folha de redistribuição do nitrogēnio para os frutos em crescimento. Da fase de "chumbinho" até aos 168 dias apro ximadamente, ficou caracterizado como o período de maior demanda de nitrogēnio pelos frutos.

Para fins de diagnose foliar, parece ser mais indicado utilizar folhas de ramos com frutos por apresentar uma maior dependência 
entre a concentração de $\mathrm{N}$ e o desenvolvimento dos frutos.

SILVA e SILVA (1956), estudando a variação de composição mineral de folhas de cafeeiro, verificaram que as folhas colhidas em ra mos sem frutos foram, em média, mais ricas em nitrogênio do que as coIhidas em ramos com frutos, sendö este resultado semelhante ao obtido no presente trabalho.

CHAVERRI et alii (1957), na Costa Rica estudando as variações mensais de $\mathrm{N}$ nas folhas do 40 par em cafeeiros arābica, observaram maior concentração no período de maior quantidade de chuvas.

LOUE (1958), utilizando o 30 par de folhas de cafeeiros robusta, verificou que maior teor de $\mathrm{N}$ foi encontrado na época de máxima vegetação.

CATANI e MORAES (1958), verificaram em cafeeiros de variedade Bourbon Vermelho que a concentração de nitrogēnio nas folhas foi mais elevada na época de inīcio da formação dos frutos do que no pe ríodo de maturação dos mesmos.

LOTT et alii (1961), fazendo um levantamento de cafezais em São Paulo e Paranā pela anālise foliar, citam teores médios de nitrogênio (N) de $2,85 \% ; 2,64 \%$ e $2,75 \%$ no verão (início de formação dos frutos); outono (desenvolvimento dos frutos e maturação) e primavera (florescimento), respectivamente no Estado de São Paulo. Para o Estado do Paranā, estas concentrações foram de 3,00\%; 2,84\% e 2,73\%.

BONNET (1969), amostrando folhas de cafeeiros Caturra e Bourbon Vermelho no estādio de desenvolvimento dos frutos (final de 
verão) e no final do inverno, constatou teor de nitrogénio mais elevado no verão.

\subsection{Fōsforo}

\subsubsection{Concentração}

Os valores da concentração de fósforo dos frutos, das foThas de ramos com frutos e das folhas de ramos sem frutos, em função da ēpoca de amostragem, acham-se na Tabela 9.

A anālise da variância da concentração de fōsforo dos frutos, em função do seu desenvolvimento, encontra-se exposta na Tabela 6 , verificando-se que houve efeito de ēpoca.

Aos teores de fōsforo dos frutos, ajustou-se uma equação de regressão quadrātica, conforme verifica-se na Figura 4, sendo que nas concentrações estimadas, os valores diminuiram de $0,18 \%$ para um mínimo de $0,10 \%$ dos 21 aos 197 dias após o inīcio do aparecimento de "chumbinho".

A concentração de fósforo dos frutos declinou sensivelmente no periodo que coincidiu com o maior desenvolvimento dos mesmos. MORAES e CATANI (1964), estudando a absorção de elementos minerais pelos frutos do cafeeiro verificaram teor de fósforo mais elevado no estādio "chumbinho" $(0,14 \%$ P) e menor durante o perīodo denominado de "verde aquoso" (0,10\% P). 
Tabela 9. Concentração (\%) de fósforo dos frutos, das folhas de ramos com frutos e das folhas de ramos sem frutos, em função da época de amostragem (média de 6 repetições)

\begin{tabular}{|c|c|c|c|c|}
\hline \multirow[t]{2}{*}{ Epoca* } & \multirow{2}{*}{ Frutos } & \multicolumn{3}{|c|}{ Folha } \\
\hline & & Ramos & com frutos & Ramos sem frutos \\
\hline 21 & 0,19 & & 0,12 & 0,10 \\
\hline 42 & 0,16 & & 0,10 & 0,10 \\
\hline 63 & 0,15 & & 0,10 & 0,11 \\
\hline 84 & 0,14 & & 0,09 & 0,10 \\
\hline 105 & 0,12 & & 0,09 & 0,09 \\
\hline 126 & 0,10 & & 0,08 & 0,08 \\
\hline 147 & 0,10 & & 0,07 & 0,09 \\
\hline 168 & 0,10 & & 0,08 & 0,08 \\
\hline 189 & 0,11 & & 0,08 & 0,11 \\
\hline 210 & 0,10 & & 0,08 & 0,08 \\
\hline 231 & 0,10 & & 0,09 & 0,10 \\
\hline 252 & 0,10 & & 0,08 & 0,08 \\
\hline d.m.s. (Tukey 5\%) & 0,04 & & 0,02 & 0,02 \\
\hline
\end{tabular}




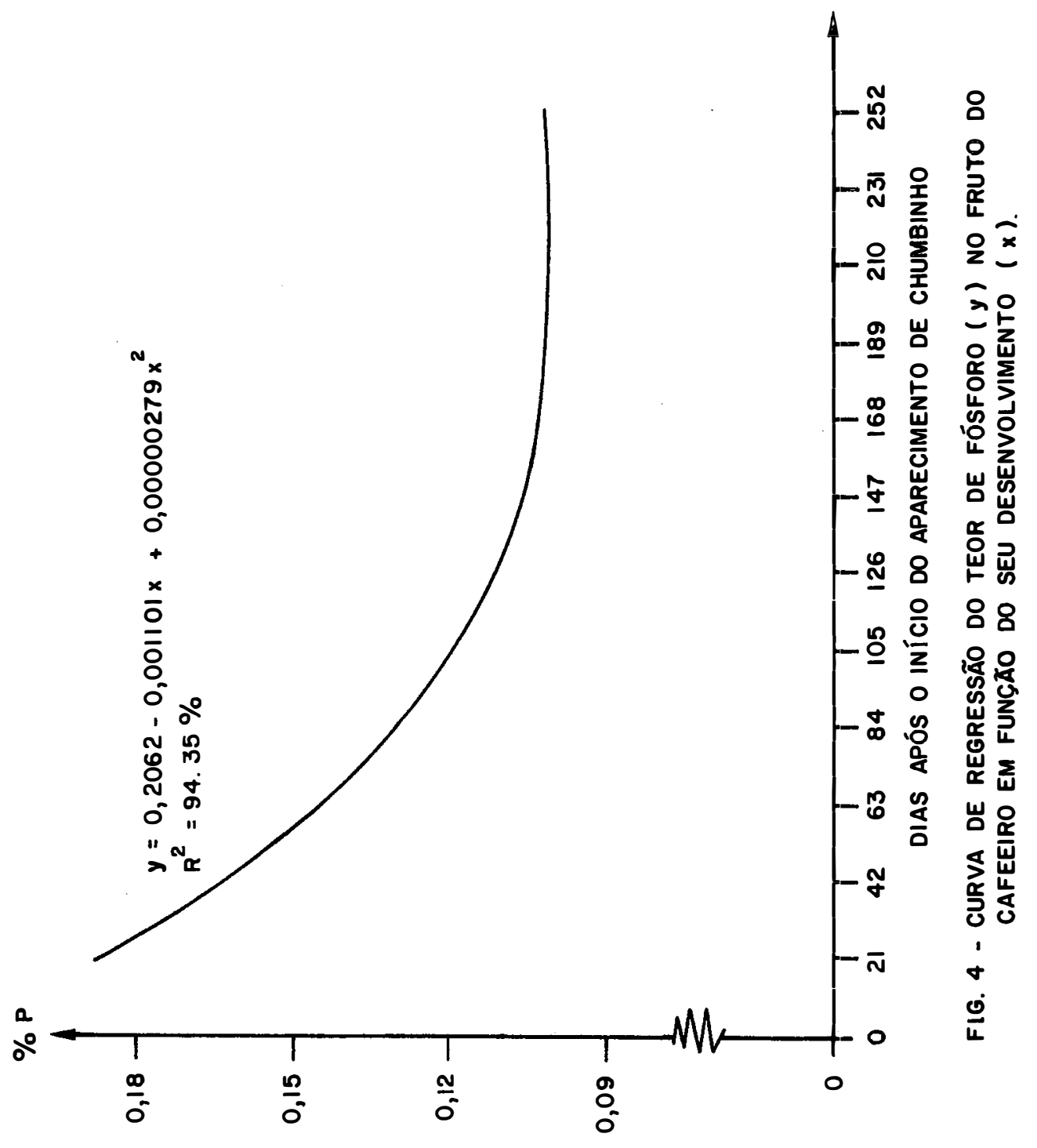


Jā CATANI et alii (1967b), trabalhando com cafeeiros Bourbon Vermelho, verificaram uma diminuição na concentração de $P$ dos frutos de $0,30 \%$ no início de sua formação para $0,16 \%$ na maturação.

Com relação às folhas, a anālise da variância da concentração de fósforo das folhas de ramos com frutos e das folhas de ramos sem frutos, em função da época de amostragem, pode ser vista na Tabela 8. A concentração de fósforo foi afetada pela época interagindo com tị po de folha.

Os teores de fósforo das folhas de ramos com frutos, diminuiram com a época de amostragem segundo uma equação de regressão qua drātica, mostrada na Figura 5, sendo que nas concentrações estimadás, os valores diminuiram de $0,12 \%$ para um minnimo de $0,08 \%$ dos 21 aos 171 dias apōs o inīcio do aparecimento de "chumbinho".

Nas folhas de ramos sem frutos, os teores de fösforo diminuiram linearmente com a época de amostragem, conforme Figura 5, sendo que nas concentrações estimadas, os valores diminuiram de $0,10 \%$ para $0,08 \%$ da primeira à ūitima amostragem.

Embora a variação da concentração de fósforo nos dois tipos de folhas seja distinta ao longo do desenvolvimento dos frutos, em média, o teor de fósforo foi mais elevado nas folhas de ramos sem frutos.

Nas folhas de ramos com produção, os teores de fósforo foram mais elevados nos estádios iniciais de crescimento dos frutos, sendo que a concentração diminuiu de forma mais acentuada atē aos 147 


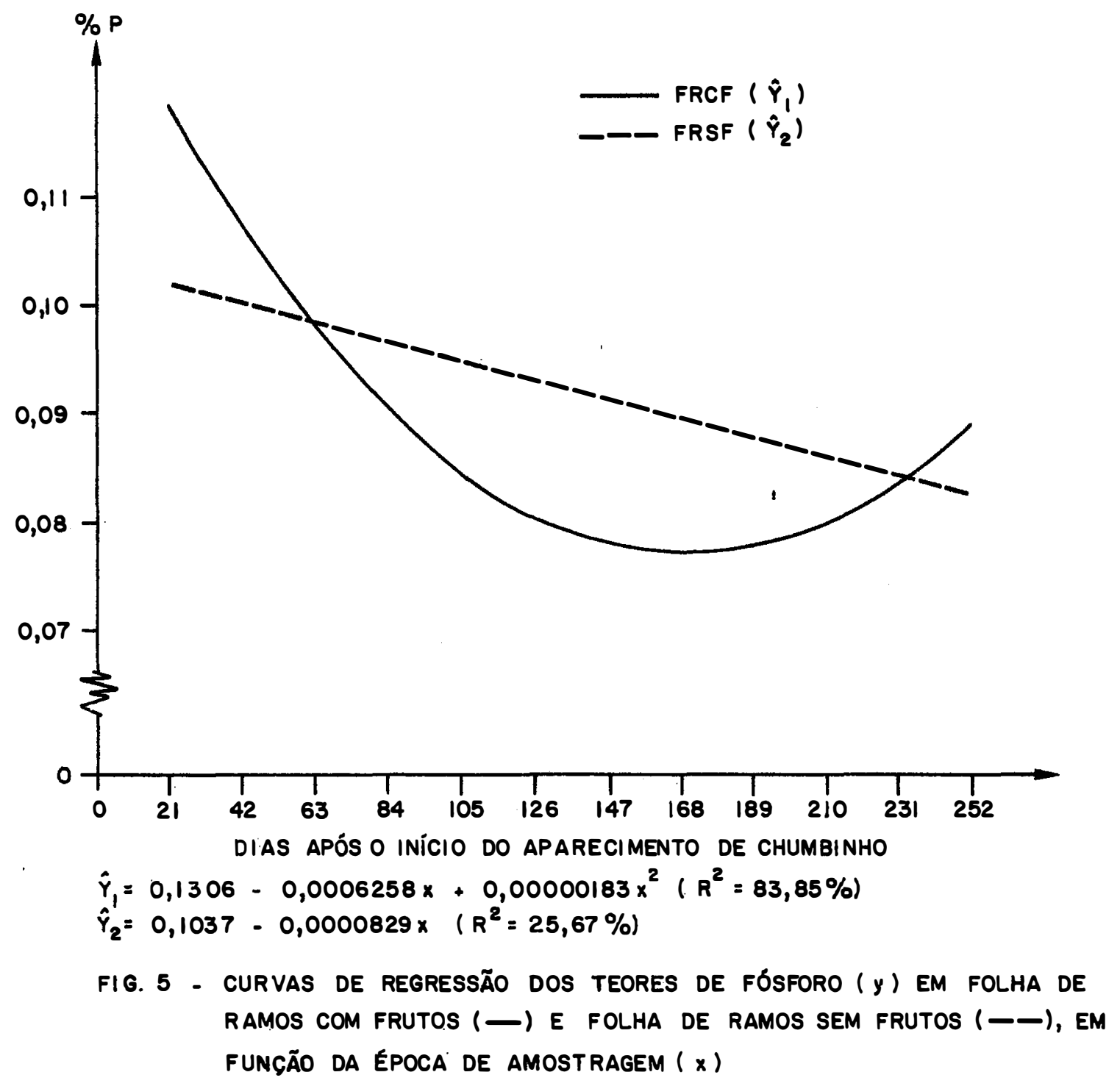


dias, provavelmente ocorrendo neste perĩodo uma redistribuição mais intensa do elemento. Apōs atingir uma concentração mīnima de $0,08 \%$, os teores de fósforo voltaram a aumentar neste tipo de folha, indicando uma diminuição na redistribuição e ou aumento na taxa de absorção do elemento.

Jā nas folhas de ramos sem produção, os teores de fōsforo diminuiram linearmente desde o estágio "chumbinho" atē a maturação dos frutos, evidenciando que a redistribuição do elemento também ocorreu neste tipo de folha, embora em menor intensidade, durante o processo de desenvolvimento dos frutos.

Ao que tudo indica, para fins de diagnose foliar, as foThas de ramos com frutos devem ser as utilizadas por representar mais adequadamente a demanda de $P$ pelos frutos.

MEDCALF et alii (1955), realizando determinações mensais de fósforo nas folhas de cafeeiros, encontraram teores mais baixos no periodo de pleno desenvolvimento dos frutos e mais elevados no início da formação dos mesmos.

SILVA e SILVA (1956), analisando folhas de cafeeiros per tencentes a ramos com frutos e ramos sem frutos, concluiram que 0 teor de fósforo, em média, foi maior nas folhas de ramos sem frutos. Resultados semelhantes foram obtidos no presente trabalho.

CHEVERRI et alii (1957), na Costa Rica, estudando as variações mensais de $P$ nas folhas do 40 par em cafeeiros arābica, observaram maior concentração no periodo de maior quantidade de chuvas. 
CATANI e MORAES (1958), verificaram teor mais elevado de fósforo nas folhas, no perīodo de formação dos frutos.

LOTT et alii (1961), fazendo um levantamento de cafezais de São Paulo e Paranā pela anālise foliar, verificaram teores médios de fósforo $(P)$ de $0,13 \% ; 0,126 \%$ e $0,16 \%$ no verão (desenvolvimento dos frutos), outono (maturação dos frutos) e primavera (florescimento), respectivamente no Estado de São Paulo. Para o Estado do Paranā, foram en contrados em média nas mesmas ēpocas, $0,146 \% ; 0,126 \%$ e $0,135 \%$.

Jä SILVA e SOUZA et alii (1975), estudanao as varraçoes no teor de alguns elementos minerais dos frutos e folhas do cafeeiro, constataram teores de fósforo das folhas relativamente constantes à medidà do desenvolvimento dos frutos.

\subsection{Potāssio}

\subsubsection{Concentração}

Os valores de concentração de potāssio dos frutos, das folhas de ramos com frutos e das folhas de ramos sem frutos, em função da épocia de amostragem, encontram-se na Tabela 10.

A anālise da variância da concentração de potāssio dos frutos, em função do seu desenvol»imento, acha-se na Tabela 6, onde pode ser verificado que houve efeito da época.

Aos teores de potāssio dos frutos ajustou-se uma equação de regressão cúbica, como a mostrada na Figura 6 , sendo que o teor diminuiu de $3,21 \%$ para um mínimo de $2,65 \%$ dos 21 aos 92 dias após o inīcio 
Tabela 10. Concentração (\%) de potāssio dos frutos, das folhas de ramos com frutos e das folhas de ramos sem frutos, em função da época de amostragem (média de 6 repetições)

\begin{tabular}{llll}
\hline \multirow{2}{*}{ Epoca* } & Frutos & \multicolumn{2}{c}{ Folhas } \\
\cline { 3 - 4 } 21 & 3,31 & 3,28 & 2,84 \\
42 & 2,78 & 2,80 & 2,82 \\
63 & 2,69 & 2,74 & 2,38 \\
84 & 2,74 & 2,29 & 2,22 \\
105 & 2,55 & 2,22 & 2,36 \\
126 & 2,70 & 2,10 & 2,28 \\
147 & 2,87 & 1,77 & 1,80 \\
168 & 3,15 & 2,09 & 2,22 \\
189 & 2,88 & 2,17 & 2,37 \\
210 & 2,95 & 2,32 & 2,21 \\
231 & 2,73 & 2,20 & 2,26 \\
252 & 2,97 & 3,01 & 2,70 \\
\hline d.m.s. (Tukey $5 \%)$ & 0,32 & 0,59 & 0,59 \\
\hline
\end{tabular}

* Dias apōs o início do aparecimento de "chumbinho" 


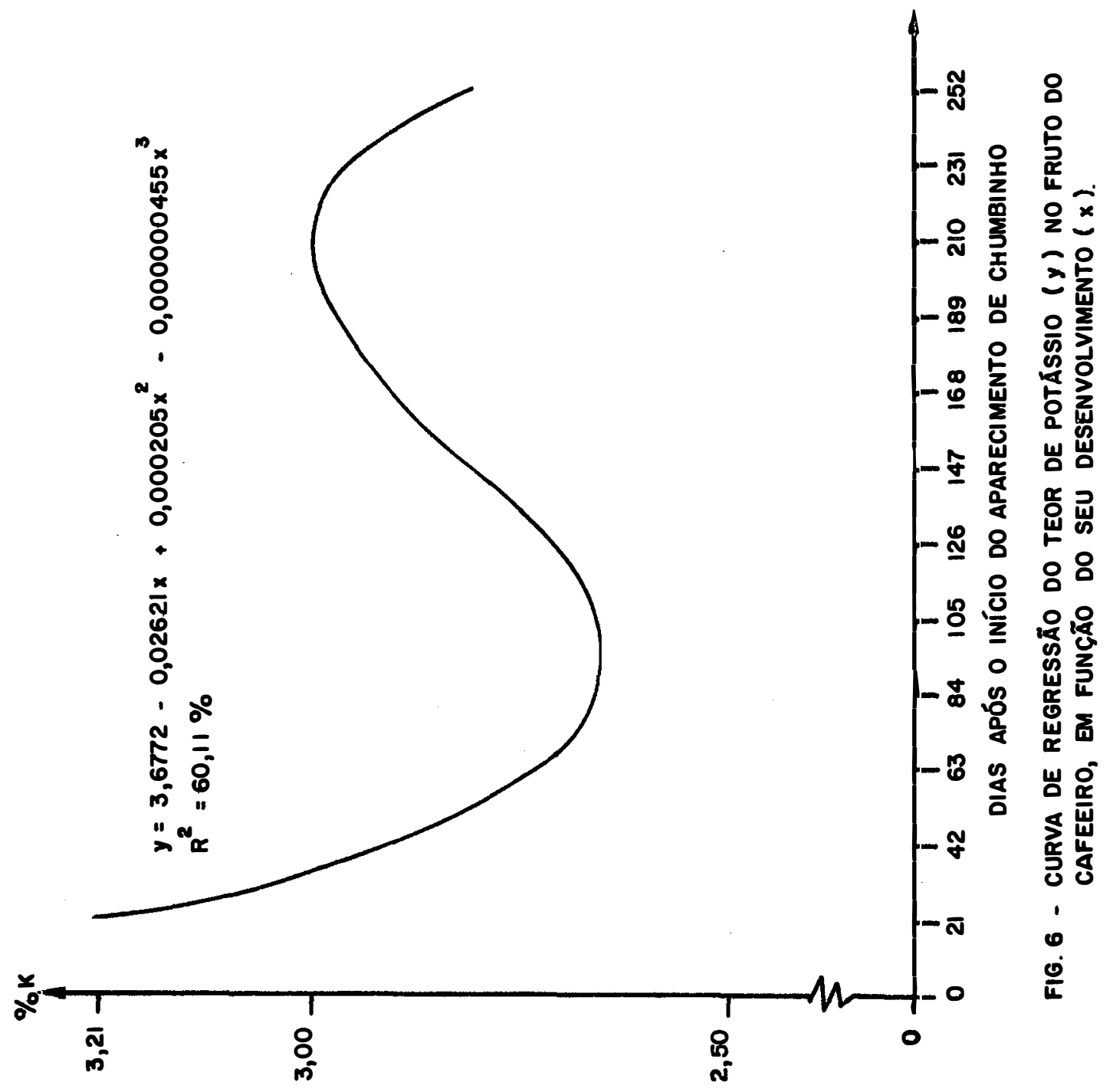


do aparecimento de "chumbinho". Apōs esta fase a concentração aumentou até 208 dias com $3,00 \%$, sendo o ponto de inflexão estabelecido aos 150 dias com $2,82 \%$.

CATANI e MORAES (1958), analisando frutos do cafeeiro no inīcio de sua formação e na maturação, verificaram que no inĩcio da formação, os teores de potāssio foram mais elevados.

MORAES e CATANI (1964), estudando a absorção de elementos minerais pelos frutos do cafeeiro durante a sua formação encontraram concentração de $2,71 \%$ de $K$ no inĩcio de formação (chumbinho) e.2,24\% na "cereja", havendo no estádio denominado de "verde aquoso" 2,08\%.

CATANI et alii (1967b), verificando a variação da concen tração de macro e micronutrientes dos frutos do cafeeiro, durante o seu desenvolvimento, encontraram teor de $K$ de $2,84 \%$ na fase de inīcio de formação e $2,33 \%$ na de maturação, variando pouco durante esse período. SILVA e SOUZA et alii (1975), estudando as variações do teor de alguns elementos minerais dos frutos do cafeeiro, constataram uma ligeira redução da concentração de potāssio desde os estádios iniciais de crescimento atē a sua maturação.

Com relação às folhas, a anālise da variância da concentração de potássio das folhas de ramos com frutos e das folhas de ramos sem frutos, em função da época de amostragem, pode ser vista na Tabela 8. A concentração de potāssio foi afetada pela ēpoca interagindo com tipo de folha. 
Os teores de potāssio das folhas de ramos com frutos, di minuiram com a época de amostragem, segundo uma equação de regressão quadrātica, conforme Figura 7 , sendo que nas concentrações estimadas, os valores diminuiram de $3,30 \%$ para um mînimo de $1,99 \%$ dos 21 aos 150 dias apōs o inīcio do aparecimento de "chumbinho".

Nas folhas de ramos sem frutos, aos teores de potássio ajustou-se uma equação de regressão quadrātica, conforme Figura 7 , sendo que nas concentrações estimadas, os valores diminuiram de $2,90 \%$ para um minnimo de $2,12 \%$ dos 21 aos 151 dias após o início do aparecimento de "chumbinho".

A variação na concentração de potāssio nos dois tipos de folhas se apresentou de forma muito semelhante, ao longo do desenvolvimento dos frutos, porēm, em média, o teor do elemento foi ligeiramente mais elevado nas folhas de ramos com frutos. Possivelmente, os altos teores de potássio no solo (Tabela 1) explique este fato.

Nas folhas de ramos com produção, os teores de potássio foram mais elevados nos estádios iniciais de crescimento dos frutos, sendo que a concentração baịxou acentuadamente atē aos 147 dias, caracterizando este período provavelmente como o de maior exigência pelos frutos. Posteriormente, a concentração de potāssio aumentou evidencian do acumulação do mesmo, possivelmente devido a uma menor redistribuição do elemento e ou uma maior absorção pela planta. 


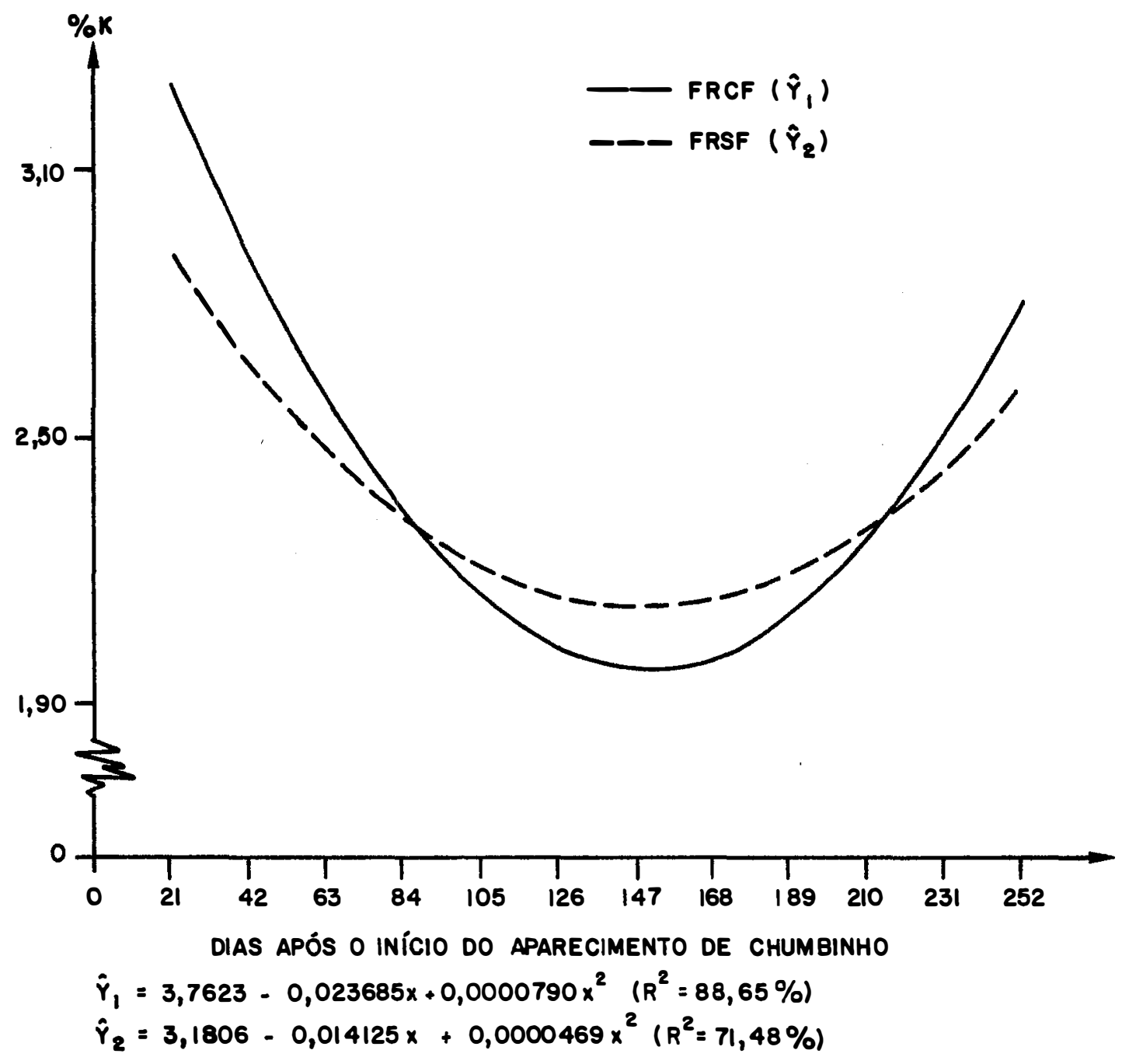

FIG. 7 - CURVAS DE REGRESSÃO DOS TEORES DE POTÁSSIO (y) EM FOLHA DE RAMOS COM FRUTOS (-) E FOLHA DE RAMOS SEM FRUTOS (-) EM FUNĢÃO DA ÉPOCA DE AMOSTRAGEM $(x)$. 
Nas folhas de ramos sem produção, os teores de potāssio variaram de forma muito semelhante aos das folhas de ramos com produção, havendo inicialmente uma redução no seu teor. Posteriormente, a concen tração aumentou atē a maturação dos frutos.

Houve redistribuição do elemento nos dois tipos de foThas porēm o fenômeno ocorreu ligeiramente com maior intensidade, nas folhas de ramos com frutos.

MEDCALF et alii (1955), fizeram determinações mensais de potássio nas folhas de cafeeiro arābica, encontrando teores mais baixos na época de desenvolvimento final dos frutos.

SILVA e SILVA (1956), estudando a variação de composição mineral de folhas de cafeeiros, verificaram que as folhas colhidas em ramos sem frutos foram, em média, mais ricas em potássio do que as coThidas em ramos com frutos. Estes resultados discordam dos encontrados no presente trabalho provavelmente por termos trabalhado com solo muito rico em potássio.

CATANI e MORAES (1958), verificaram em cafeeiros de variedade "Bourbon Vermelho" que a concentração do potāssio nas folhas foi mais elevada na época de inĩcio de formação dos frutos do que no pe rĩodo de maturação dos mesmos.

LOTT et alii (1961), realizando um levantamento de cafezais em São Paulo e Paranā pela anālise foliar, citam teores médios de potássio (K) de 1,98\%; 1,79\% e 2,24\% no verão (inīcio de formação dos frutos); outono (desenvolvimento dos frutos e maturação)e primavera 
(florescimento), respectivamente no Estado de São Paulo. Para o Estado do Paranā estas concentrações foram de $2,37 \% ; 1,75 \%$ e $1,55 \%$.

BONNET (1969), amostrando folhas de cafeeiros Caturra e Bourbon Vermelho no estádio de desenvolvimento dos frutos (final do verão) e no final do inverno, constatou teor de potássio mais elevado no verão.

SILVA e SOUZA et alii (1975), estudando as variações de alguns elementos minerais das folhas de cafeeiros Mundo Novo, constataram que os teores de potássio diminuiram ligeiramente desde 0 inĩcio até o fim do ciclo de crescimento dos frutos.

\subsection{Câlcio}

\subsubsection{Concentração}

Os valores da concentração de cálcio dos frutos, das foThas de ramos com frutos e das folhas de ramos sem frutos, em função da época de amostragem, acham-se na Tabela 11.

A anāilise da variāncia da concentração de cálcio dos frü tos, em função do seu desenvolvimento, encontra-se exposta na Tabela 6 verificando-se que houve efeito de época.

Aos teores de cálcio dos frutos ajustou-se uma equação de regressão cúbica, conforme è mostrada na Figura 8, sendo que 0 teor diminuiu de $0,69 \%$ aos 21 dias para um mínimo de $0,20 \%$ aos 131 dias apōs o aparecimento de "chumbinho". Posteriormente o teor elevou-se ligeiramente atē $0,24 \%$ aos 203 dias, sendo o ponto de inflexão alcançado aos 167 dias com $0,22 \%$. 
Tabela 11. Concentração (\%) de cālcio dos frutos, das folhas de ramos com frutos e das folhas de ramos sem frutos, em função da época de amostragem (média de 6 repetições)

\begin{tabular}{llcl}
\hline \multirow{2}{*}{ Epoca* } & Frutos & \multicolumn{2}{c}{ Folha } \\
\cline { 3 - 4 } & & Ramos com frutos & Ramos sem frutos \\
\hline 21 & 0,78 & 0,88 & 0,99 \\
42 & 0,37 & 0,96 & 0,98 \\
63 & 0,32 & 1,23 & 1,23 \\
84 & 0,29 & 1,35 & 1,30 \\
105 & 0,25 & 1,34 & 1,18 \\
126 & 0,25 & 1,58 & 1,25 \\
147 & 0,25 & 1,15 & 1,06 \\
168 & 0,21 & 1,54 & 1,60 \\
189 & 0,22 & 1,48 & 1,17 \\
210 & 0,20 & 1,28 & 1,25 \\
231 & 0,18 & 1,19 & 1,19 \\
252 & 0,22 & 1,17 & 1,12 \\
\hline d.m.s. (Tukey) & 0,09 & 0,33 & 0,33 \\
Dias após o inicio do aparecimento de & 1 chumbinho". & \\
\hline
\end{tabular}




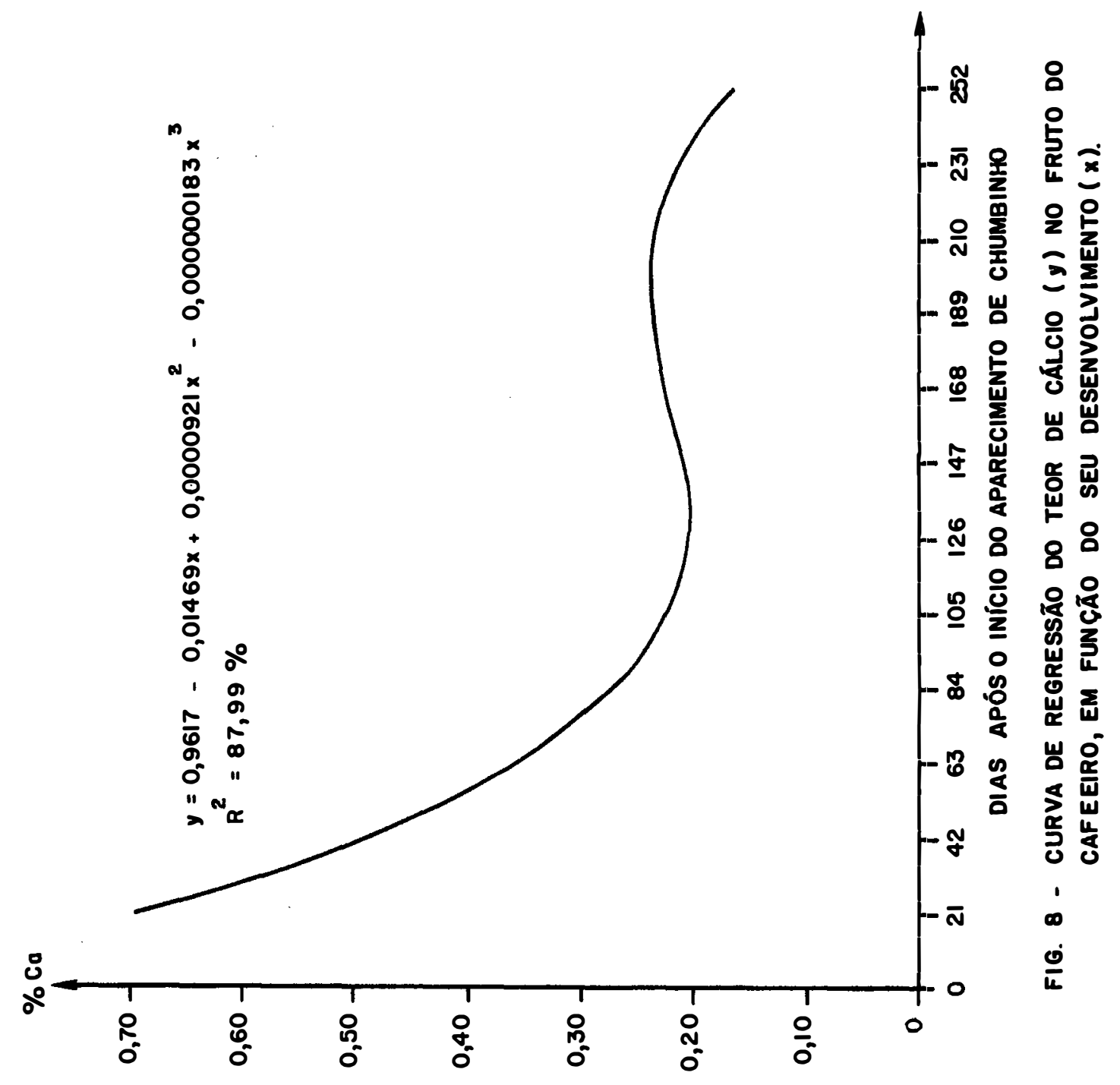


CATANI e MORAES (1958), analisando frutos do cafeeiro no início de sua formação e na maturação, verificaram teores de cálcio sempre mais elevados no perīodo inicial de formação dos mesmos.

MORAES e CATANI (1964), estudando a absorção de elementos minerais pelos frutos do cafeeiro durante sua formação verificaram uma concentração de Ca de $0,25 \%$ no estādio "chumbinho" e $0,16 \%$ quando"ce reja".

CATANI et alii (1967b), observando a variação da concentração de macro e micronutrientes dos frutos do cafeeiro. durante o seu desenvolvimento, encontraram que o teor de Ca diminuiu de $0,77 \%$ na fase de inĩcio de formação atē $0,31 \%$ na de maturação.

SILVA e SOUZA et alii (1975), constataram que os nîveis de cálcio dos frutos decresceram continuamente com a sua expansão, principalmente nos estádios iniciais de crescimento. Depois houve uma tendência para a constância.

Com relação às folhas, a anālise de variância da concentração de cálcio das folhas de ramos com frutos e das folhas de ramos sem frutos, em função da época de amostragem, pode ser vista na Tabela 8.

A concentração de cālcio foi afetada pela época e pelo tipo de folha com interação.

Os teores de cálcio das folhas de ramos com frutos, aumentaram com a época de amostragem, segundo uma equação de regressão qua drātica, mostrada na Figura 9, sendo que nas concentrações estimadas, os valores aumentaram de $0,87 \%$ para um máximo de $1,44 \%$, dos 21 aos 153 dias 
apōs o inĩcio do aparecimento de "chumbinho".

Nas folhas de ramos sem frutos, aos teores de cálcio ajus tou-se igualmente uma equação de regressão quadrātica, conforme a Figura 9, sendo que nas concentrações estimadas, os valores aumentaram de 0,98\% para um máximo de $1,29 \%$ dos 21 aos 155 dias apōs o início do apare cimento de "chumbinho".

A variação na concentração de cālcio nos dois tipos de folhas se apresentou de forma muito semelhante ao longo do desenvolvimento dos frutos, porēm, em média, o teor do elemento foi mais elevado nas folhas de ramos com frutos.

Nas folhas de ramos com produção, os teores de cálcio fọ ram mais baixos nos estádios iniciais de crescimento dos frutos, sendo que a concentração aumentou atē aos 153 dias, caracterizando este período provavelmente como sendo o de maior absorção e acumulação pela planta. Após este período houve uma redução na concentração de cālcio.

Nas folhas de ramos sem produção, os teores de cālcio variaram de forma semelhante aos das folhas de ramos sem produção, sendo as concentrações mais baixas no início da formação dos frutos, aumentando atē aos 155 dias.

Este comportamento do cálcio em ambos os tipos de folhas caracteriza a baixa redistribuição do elemento das folhas para os frutos, sugerindo, que o suprimento de cálcio pelo solo deva ser contínuo, durante toda a frutificação. 


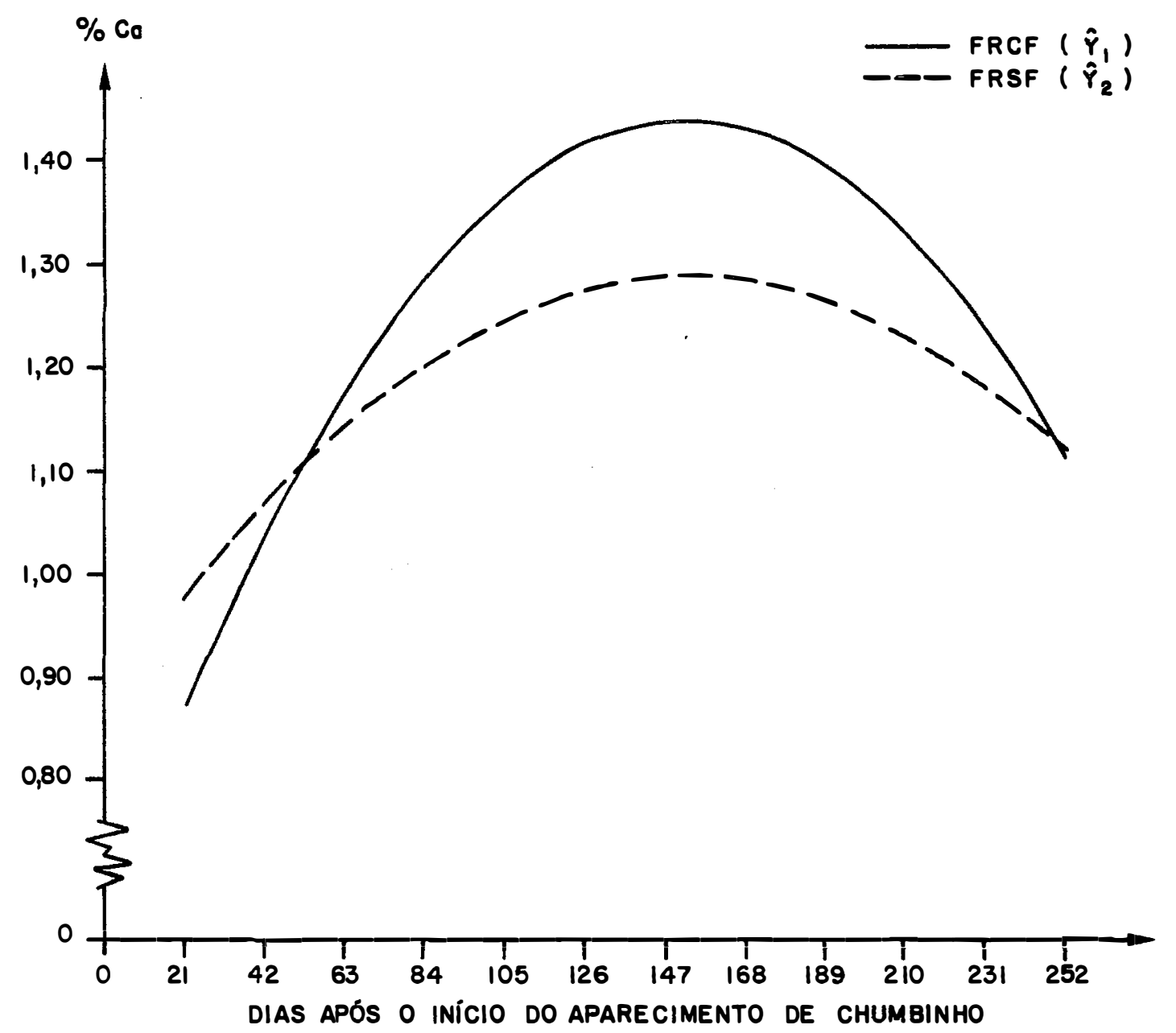

$\hat{Y}_{1}=0,6724+0,010077 x-0,0000329 x^{2} \quad\left(R^{2}=70,45 \%\right)$

$\hat{Y}_{2}=0,8700+0,005444 x-0,00001756 x^{2} \quad\left(R^{2}=35,92 \%\right)$

FIG. 9 - CURVAS de REgRessão dos teores de CÁlCIO (y) EM FOLHA de RAMOS COM FRUTOS (-) E FOLHA DE RAMOS SEM FRUTOS (- ), EM FUNÇÃo DA ÉPOCA DE AMOSTRAGEM $(x)$. 
SILVA e SILVA (1956), estudando a variação de composição mineral de folhas de cafeeiros, verificaram que as folhas colhidas de ramos sem frutos foram, em média, mais pobres em cálcio do que as colhidas em ramos com frutos. Resultados semelhantes foram obtidos no pre sente trabalho.

CATANI e MORAES (1958), verificaram em cafeeiros de variedade Bourbon Vermelho que a concentração de cālcio nas folhas foi mais baixa na época de início de formação dos frutos do que no periodo de maturação dos mesmos.

LOTT et alii (1961), realizando um levantamento de cafezais em São Paulo e Paranā pela anālise foliar, citam teores médios de cálcio (Ca) de $1,07 \% ; 1,12 \%$ e $0,93 \%$, no verão (início de formação dos frutos); outono (desenvolvimento dos frutos e maturação) e primavera (flo rescimento), respectivamente no Estado de São Paulo. Para o Estado do Paranā estas concentrações foram de 1,08\%; 1,19\% e 1,23\%.

BONNET (1969), amostrando folhas de cafeeiro Caturra e Bourbon Vermelho no estádio de desenvolvimento dos frutos (final de verão) e no final do inverno, constatou teor de cálcio mais elevado no inverno.

SILVA e SOUZA et alii (1975), estudando as variações de alguns elementos minerais nas folhas de cafeeiros Mundo Novo, constataram que os teores de cálcio apresentaram uma tendēncia para crescimento lento com o correr da estação. 


\subsection{Magnēsio}

\subsubsection{Concentração}

Os valores da concentração de magnésio dos frutos das foThas de ramos com frutos e das folhas de ramos sem frutos, em função da época de amostragem, acham-se na Tabela 12.

A anālise da variāncia da concentração de magnēsio dos fru tos, em função do seu desenvolvimento, encontra-se na Tabela 6 , verificando-se que houve efeito de época.

Aos teores de magnésio dos frutos ajustou-se uma equação de regressão cúbica, conforme é mostrado na Figura 10, sendo que o teor diminuiu de $0,35 \%$ para um mīnimo de $0,17 \%$ dos 21 aos 106 dias apōs o inī cio do aparecimento de "chumbinho". Posteriormente a concentração aumentou, atingindo o ponto de inflexão aos 151 dias com $0,19 \%$ indo até $0,21 \%$ aos 197 dias.

CATANI e MORAES (1958), analisando frutos do cafeeiro no início de sua formação e na maturação verificaram que no inīcio da formação, os teores de magnésio foram mais elevados.

MORAES e CATANI (1964), estudando a absorção de elementos minerais pelo fruto do cafeeiro durante a sua formação, verificaram concentração de $24 \%$ de Mg no "chumbinho" e 0,07\% na "cereja".

CATANI et alii (1967b), observando a variação na concentração de macro e micronutrientes do fruto do cafeeiro, durante o seu de senvolvimento, constataram que o teor de Mg diminuiu de $0,15 \%$ na fase de inỉcio de formação atē $0,07 \%$ na fase de maturação. 
Tabela 12. Concentração (\%) de magnēsio dos frutos, das folhas de ramos com frutos e das folhas de ramos sem frutos, em função da epoca de amostragem (média de 6 repetições)

\begin{tabular}{|c|c|c|c|c|}
\hline \multirow{2}{*}{ Epoca* } & \multirow{2}{*}{ Frutos } & \multicolumn{3}{|c|}{ Folhas } \\
\hline & & Ramos com Frutos & Ramos & sem Frutos \\
\hline 21 & 0,39 & 0,33 & & 0,32 \\
\hline 42 & 0,21 & 0,28 & & 0,29 \\
\hline 63 & 0,20 & 0,30 & & 0,33 \\
\hline 84 & 0,19 & 0,26 & & 0,31 \\
\hline 105 & 0,19 & 0,27 & & 0,31 \\
\hline 126 & 0,18 & 0,36 & & 0,38 \\
\hline 147 & 0,20 & 0,40 & & 0,36 \\
\hline 168 & 0,22 & 0,52 & & 0,60 \\
\hline 189 & 0,21 & 0,37 & & 0,47 \\
\hline 210 & 0,18 & 0,33 & & 0,43 \\
\hline 231 & 0,17 & 0,43 & & 0,44 \\
\hline $25 ?$ & 0,17 & 0,27 & & 0,35 \\
\hline d.m.s. (Tukey) & 0,04 & 0,16 & & 0,16 \\
\hline
\end{tabular}




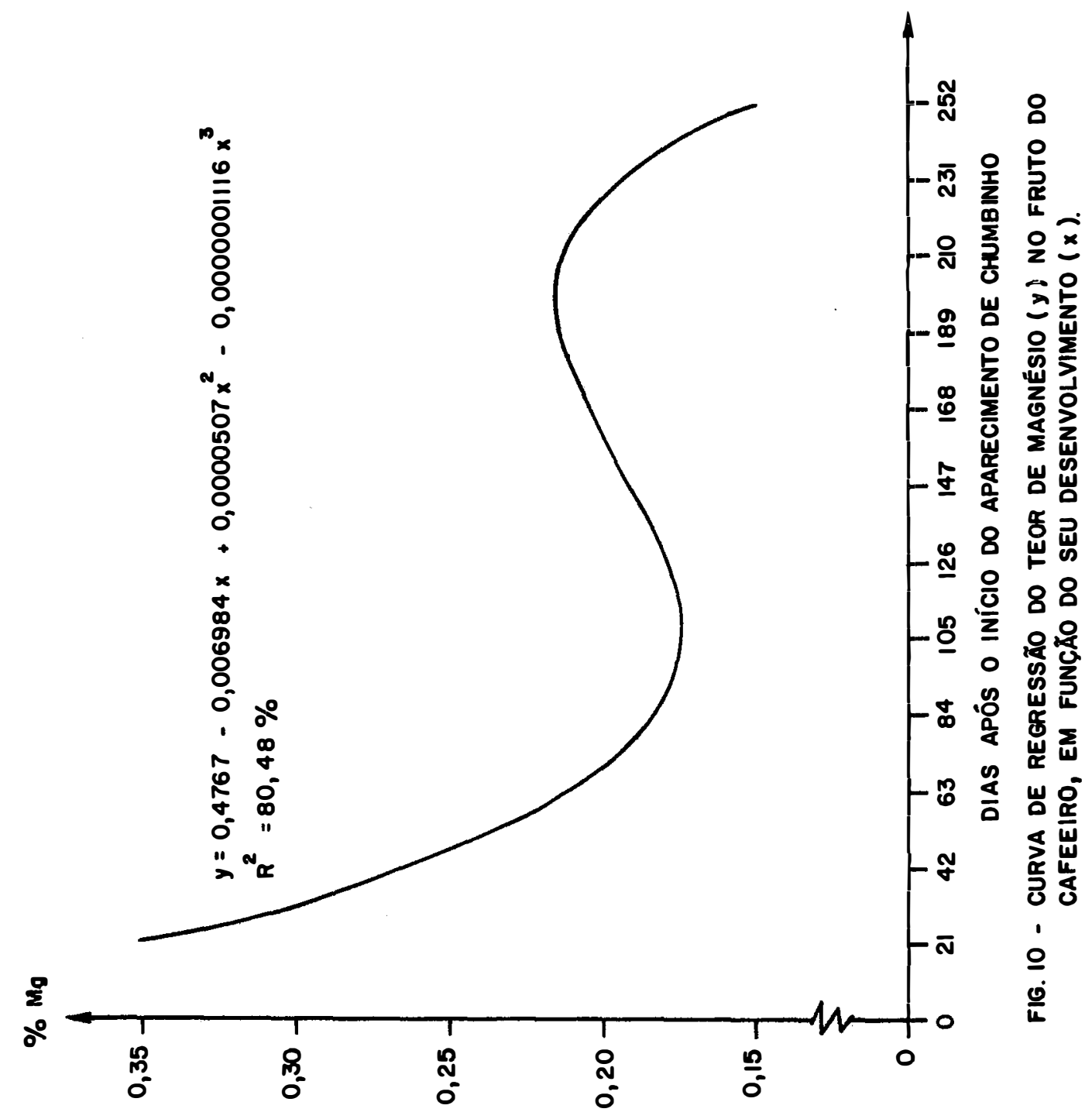


SILVA e SOUZA et alii (1975), avaliando as variações no teor de alguns elementos minerais dos frutos do cafeeiro, encontraram que o teor de magnésio cai muito a princípio e depois lentamente.

Com relação ãs folhas, a anālise da variância da concentração de magnésio das folhas de ramos com frutos e das folhas de ramos sem frutos, em função da época de amostragem, pode ser vista na Tabela 8. A concentração de magnésio foi afetada pela época e pelo tipo de foTha com interação.

Aos teores de magnésio das folhas de ramos com frutos, ajustou-se uma equação de regressão cúbica, mostrada na Figura 11. As concentrações diminuiram a princīpio atingindo um mínimo de $0,27 \%$ aos 62 dias apōs o inîcio do aparecimento de "chumbinho". Posteriormente houve um aumento, sendo que o ponto de inflexão se situou aos 126 dias com $0,35 \%$ e o teor máximo alcançado aos 189 dias com $0,43 \%$.

Nas folhas de ramos sem frutos, aos teores de magnésio ajustou-se igualmente uma equação de regressão cúbica, conforme a Figura 11, com o teor mỉnimo sendo alcançado aos 56 dias após o inīcio do aparecimento de "chumbinho" com 0,29\%. Posteriormente as concentrações aumentaram, sendo que o ponto de inflexão se situou aos 124 dias com 0,39\% e o teor máximo atingido aos 193 dias com 0,49\%.

A variação na concentração de magnésio nos dois tipos de folhas se apresentou de forma muito semelhante, ao longo do desenvolvimento dos frutos, porém, em média, o teor do elemento foi mais elevado nas fol has de ramos sem frutos. 


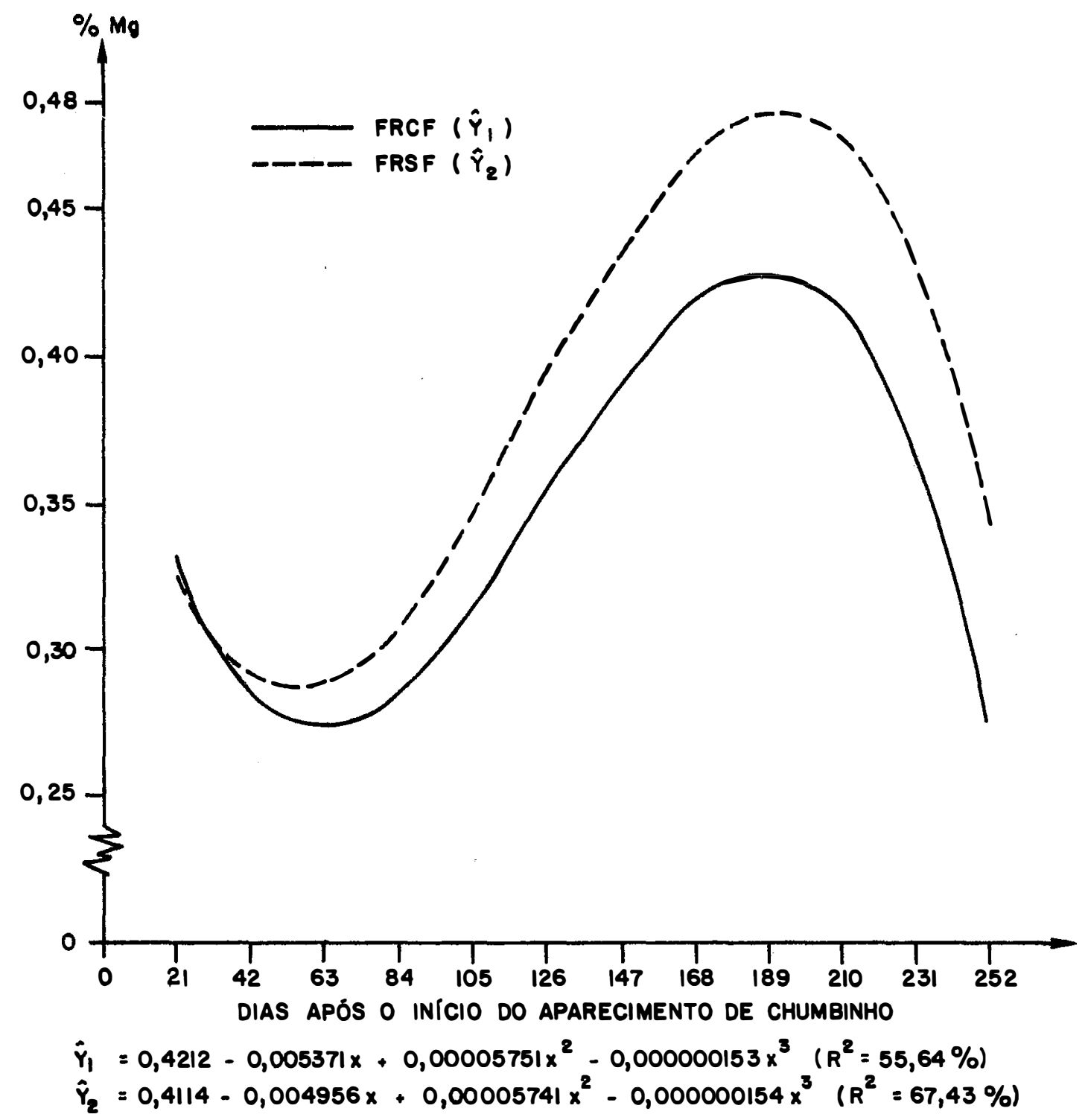

FIG. II - CURVAS DE REGRESSÃO DOS TEORES DE MAGNÉSIO (y) EM FOLHA DE RAMOS COM FRUTOS (-) E FOLHA DE RAMOS SEM FRUTOS (- -), EM FUNÇÄO DA ÉPOCA DE AMOSTRAGEM $(x)$. 
Também o magnésio, no cafeeiro, parece apresentar pequena mobilidade, sugerindo um contīnuo fornecimento de magnésio pelo solo, afim de atender as exigências dos frutos.

SILVA e SILVA (1956), estudando a variação de composição mineral de folhas de cafeeiros, verificaram que as folhas colhidas de ramos sem frutos foram, em média, mais pobres em magnésio do que as coIhidas em ramos com frutos. No presente trabalho estes resultados não foram confirmados.

CATANI e MORAES (1958), observaram em cafeeiros da variedade Bourbon Vermelho que a concentração de magnésio das folhas foi mais baixa no perīodo de maturação dos frutos do que na época de inĩcio de formação dos mesmos.

LOTT et alii (1961), realizando um levantamento de cafezais em São Paulo e Paraná pela anālise foliar, citam teores médios de magnésio $(\mathrm{Mg}$ ) de $0,37 \%$; $0,36 \%$ e $0,30 \%$, no verão (início de formação dos frutos); outono (desenvolvimento dos frutos e maturação) e primavera(flo rescimento) respectivamente no Estado de São Paulo. Para o Estado do Pa ranā estas concentrações foram de $0,36 \% ; 0,37 \%$ e $0,34 \%$.

BONNET (1969), amostrando folhas de cafeeiros Caturra e Bourbon Vermelho, no estádio de desenvolvimento dos frutos (final de verão) e no final do inverno, constatou teor de magnésio mais elevado no verão.

SILVA e SOUZA et alii (1975), estudando as variações de alguns elementos minerais nas folhas de cafeeiros Mundo Novo, constataram 
que os teores de magnésio subiram constantemente, não parecendo que tenha havido redistribuição desse nutriente para os frutos.

\subsection{Enxofre}

\subsubsection{Concentração}

Os valores da concentração de enxofre dos frutos, das foThas de ramos com frutos e das folhas de ramos sem frutos, em função da época de amostragem, acham-se na Tabela 13.

A anālise da variância da concentração de enxofre dos fru tos, em função do seu desenvolvimento, encontra-se exposta na Tabela 6 , verificando-se que houve efeito de época.

Aos teores de enxofre dos frutos, ajustou-se uma equação de regressão cúbica, conforme é mostrado na Figura 12, com o teor aumentando iniciarmente até aos 65 dias apōs o início do aparecimento de "chumbinho" com $0,14 \%$, ponto de inflexão aos 123 dias com $0,12 \%$ e teor minnimo aos 181 dias com $0,10 \%$.

CATANI et alii (1967b), estudando a variação na concentração de macro e micronutrientes nos frutos do cafeeiro, durante o seu desenvolvimento, encontraram que o teor de $S$, diminuiu de $0,26 \%$ na fase de inĩcio de formação até $0,09 \%$ na fase de maturação. 
Tabela 13. Concentração (\%) de enxofre dos frutos, das folhas de ramos com frutos e das folhas de ramos sem frutos, em função da época de amostragem (média de 6 repetições)

\begin{tabular}{|c|c|c|c|c|}
\hline \multirow{2}{*}{ Epoca* } & \multirow{2}{*}{ Frutos } & \multicolumn{3}{|c|}{ Folhas } \\
\hline & & Ramos & com Frutos & Ramos sem Frutos \\
\hline 21 & 0,15 & & 0,10 & 0,07 \\
\hline 42 & 0,10 & & 0,08 & 0,10 \\
\hline 63 & 0,12 & & 0,09 & 0,14 \\
\hline 84 & 0,14 & & 0,14 & 0,11 \\
\hline 105 & 0,14 & & 0,16 & 0,14 \\
\hline 126 & 0,15 & & 0,15 & 0,15 \\
\hline 147 & 0,11 & & 0,17 & 0,08 \\
\hline 168 & 0,10 & & 0,08 & 0,08 \\
\hline 189 & 0,10 & & 0,12 & 0,12 \\
\hline 210 & 0,10 & & 0,09 & 0,08 \\
\hline 231 & 0,10 & & 0,12 & 0,10 \\
\hline 252 & 0,19 & & 0,17 & 0,17 \\
\hline d.m.s. (Tukey 5\%) & 0,06 & & 0,06 & 0,06 \\
\hline
\end{tabular}




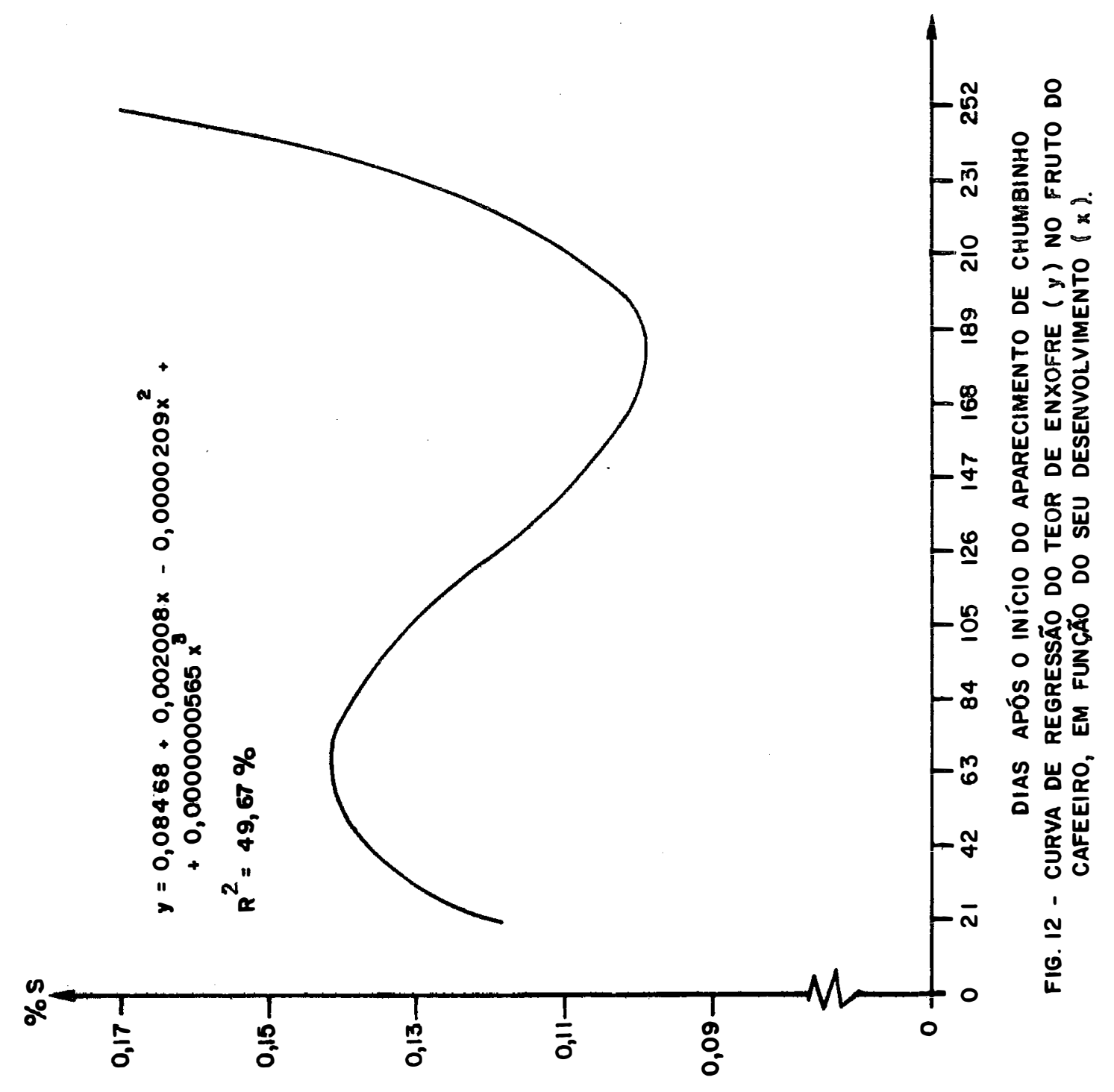


Com relação às folhas, a anālise da variāncia da concentração de enxofre das folhas de ramos com frutos e das folhas de ramos sem frutos, em função da época de amostragem, pode ser vista na Tabela 8. A concentração de enxofre foi afetada pela ēpoca interagindo com ti po de folha.

Aos teores de enxofre das folhas de ramos com frutos, ajus tou-se uma equação de regressão cúbica, conforme a Figura 13, com teor de $0,07 \%$ aos 21 dias apōs o inīcio do aparecimento de "chumbinho" subindo atē um māximo de $0,14 \%$ aos 95 dias e decrescendo em seguida para $0,11 \%$ aos 196 dias. 0 ponto de inflexão ocorreu aos 146 dias com $0,13 \%$.

Nas folhas de ramos sem frutos, aos teores de enxofre ajustou-se igualmente uma equação de regressão cūbica, conforme a Figura 13, com os teores aumentando de $0,06 \%$ aos 21 dias apōs o inī́cio do aparecimento de "chumbinho" até $0,14 \%$ aos 84 dias e diminuindo para 0,09\% aos 189 dias, com ponto de inflexão aos 137 dias com $0,11 \%$.

A variação na concentração de enxofre nos dois tipos de folhas foi muito semelhante, ao longo do desenvolvimento dos frutos, porēm, em média, o teor do elemento foi ligeiramente mais elevado na folha de ramos com frutos.

LOTT et alii (1961), realizando um levantamento de cafezais em São Paulo e Paranā pela anālise foliar, citam teores médios de enxofre - sulfato de 333 ppm; 401 ppm e 587 ppm no verão (inîcio de formação dos frutos); outono (desenvolvimento dos frutos e maturação) e pri mavera (florescimento) respectivamente no Estado de São Paulo. Para o 


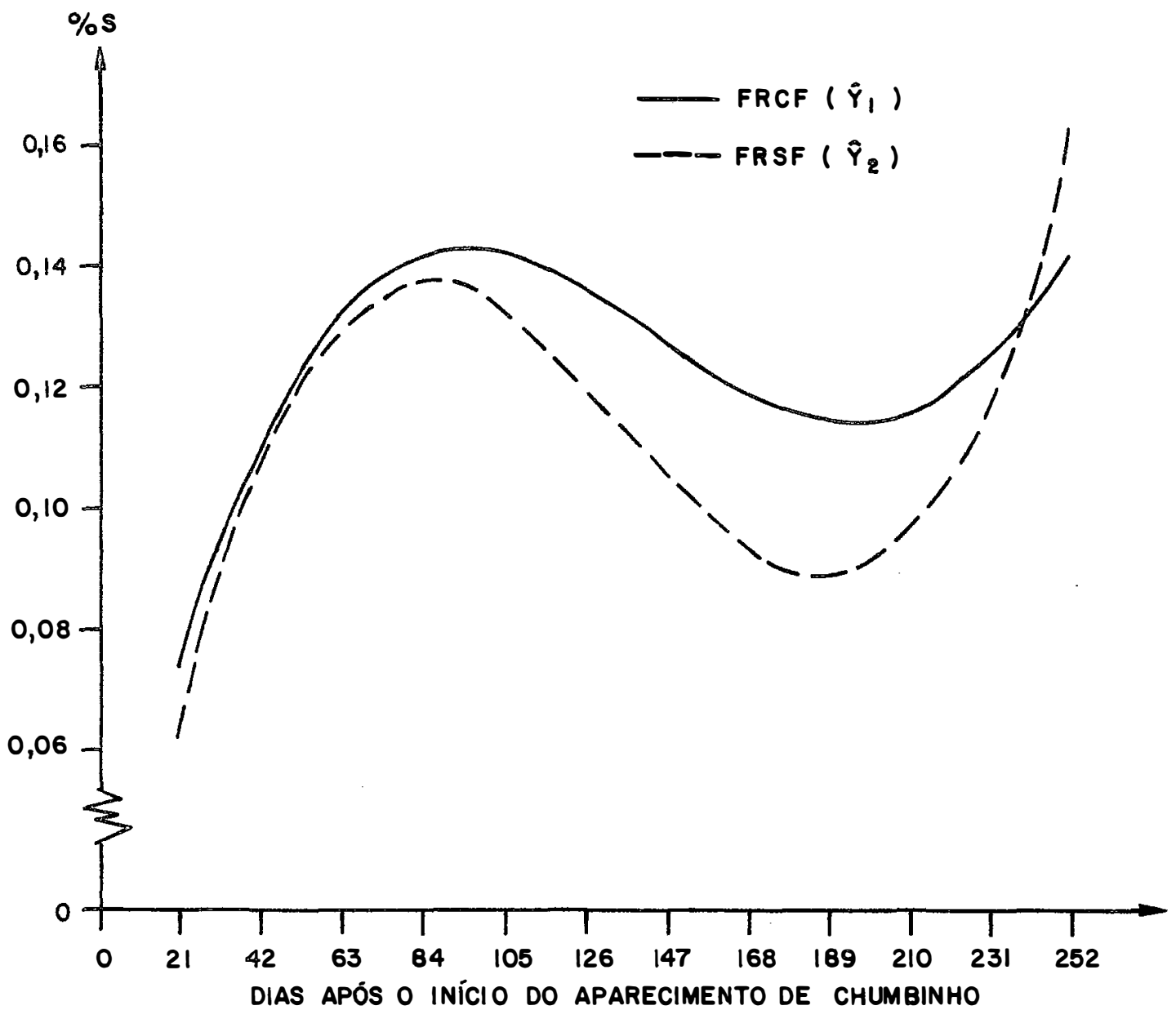

$\hat{Y}_{1}=0,0175+0,003137 x-0,00002452 x^{2}+0,000000056 x^{3} \quad\left(R^{2}=33,51 \%\right)$

$\hat{Y}_{2}=-0,0111+0,004144 x-0,00003550 x^{2}+0,000000087 x^{2}\left(R^{2}=66,80 \%\right)$

FIG. 13 - CURVAS DE REGRESSÃO DOS TEORES DE ENXOFRE ( $y$ ) EM FOLHA DE RAMOS COM FRUTOS (-) E FOLHA DE RAMOS SEM FRUTOS (- -), EM FUNÇÃO DA ÉPOCA DE AMOSTRAGEM $(x)$. 
Estado do Paranā estas concentrações foram de 348 ppm; 316 ppm e 402 ppm.

\subsection{Boro}

\subsubsection{Concentração}

Os valores da concentração de boro dos frutos, das folhas de ramos com frutos e das folhas de ramos sem frutos, em função de época de amostragem, acham-se na Tabela 14.

A anālise da variāncia da concentração de boro dos frutos, em função do seu desenvolvimento, encontra-se exposta na Tabela 15, verificando-se que a concentração foi afetada pela época.

Aos teores de boro dos frutos ajustou-se uma equação de regressão cúbica, conforme é mostrado na Figura 14, sendo que a concentração diminuiu de $42 \mathrm{ppm}$ aos 21 dias apōs o início do aparecimento de "chumbinho" para um mỉnimo de 11 ppm aos 130 dias. Posteriormente a con centração subiu atē 17 ppm aos 240 dias sendo o ponto de inflexão situado aos 185 dias com 14 ppm.

CATANI et alii (1967b), verificando a variação na concentração de macro e micronutrientes no fruto do cafeeiro, durante 0 seu desenvolvimento, encontraram, que o teor de $B$ diminuiu de 15 ppm no inîcio do desenvolvimento atē $12 \mathrm{ppm}$ na fase de maturação. 
Tabela 14. Concentração (ppm) de boro dos frutos, das folhas de ramos com frutos e das folhas de ramos sem frutos, em função da época de amostragem (média de 6 repetições)

\begin{tabular}{|c|c|c|c|}
\hline \multirow{2}{*}{ Epoca* } & \multirow{2}{*}{ Frutos } & \multicolumn{2}{|c|}{ Folhas } \\
\hline & & Ramos com frutos & Ramos sem frutos \\
\hline 21 & 46 & 66 & 66 \\
\hline 42 & 26 & 62 & 65 \\
\hline $6 \dot{3}$ & 16 & 76 & 60 \\
\hline 84 & 15 & 76 & 60 \\
\hline 105 & 16 & 77 & 60 \\
\hline 126 & 14 & 88 & 63 \\
\hline 147 & 14 & 92 & 67 \\
\hline 168 & 12 & 99 & 72 \\
\hline 189 & 12 & 79 & 57 \\
\hline 210 & 15 & 69 & 64 \\
\hline 231 & 17 & 71 & 70 \\
\hline 252 & 19 & 77 & 62 \\
\hline d.m.s. (Tukey 5\%) & 5,4 & 20,0 & 20,0 \\
\hline
\end{tabular}




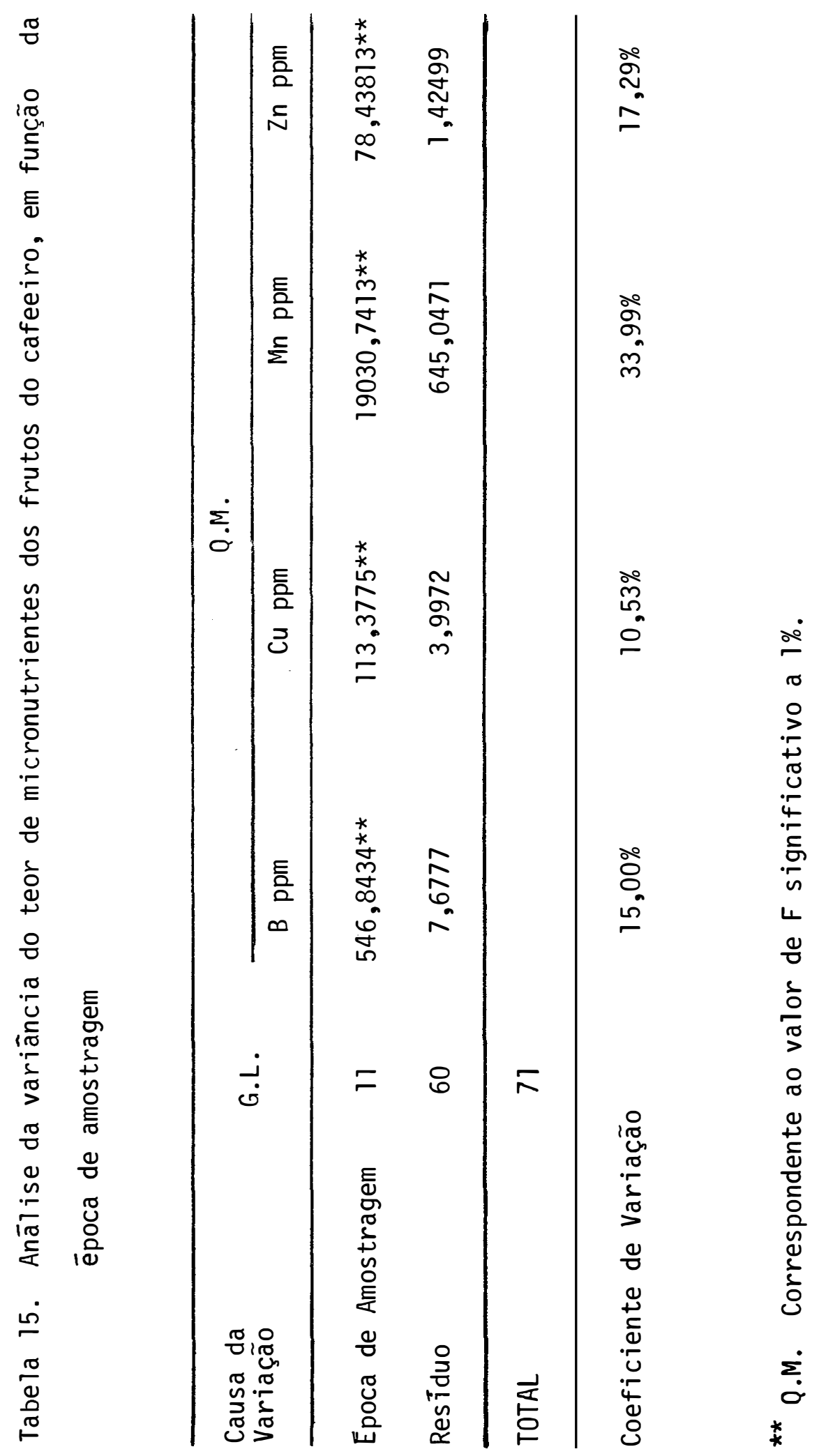




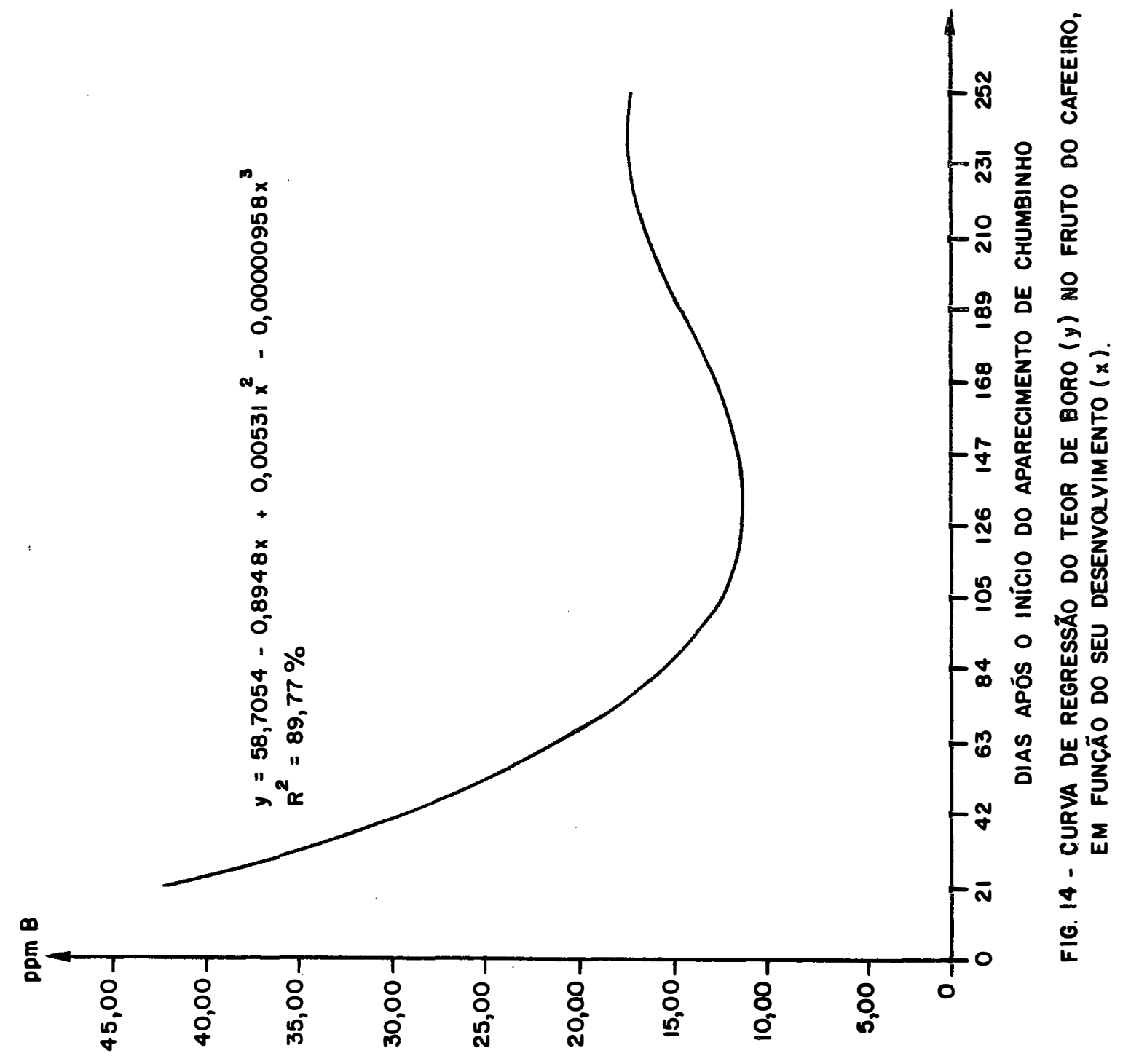


Com relação às folhas a anālise da variância da concentração de boro das folhas de ramos com frutos e das folhas de ramos sem frutos, em função da época de amostragem, pode ser vista na Tabela 16. A concentração de boro foi afetada pela época e pelos tipos de folhas com interação.

Os teores de boro das folhas de ramos com frutos, variaram segundo uma equação de regressão quadrātica, conforme Figura 15, aumentando desde aos 21 dias com 61 ppm, atē o máximo de 86 ppm aos 149 dias após o inīcio do aparecimento de "chumbinho". Posteriormente a con centração diminuiu.

Nas folhas de ramos sem frutos, não ocorreu variação de concentração estatisticamente significativa. 0 teor de $B$ se manteve ao redor de 64 ppm durante todo o perīodo de desenvolvimento e maturação dos frutos, conforme Figura 15.

Embora o comportamento do boro nos dois tipos de folhas seja completamente diferente, as folhas de ramos com frutos se mostraram mais ricas no elemento, durante toda a fase de amostragem.

Nas folhas de ramos com produção, os teores de boro foram mais baixos nos estádios iniciais de crescimento dos frutos sendo que a concentração aumentou até aos 149 dịas. Provavelmente este aumento na concentração possa ser explicado pela pouca mobilidade do boro na planta, acumulando-se nas folhas e também pelo periodo mais favorável de sua absorção. Após aos 149 dias, a concentração começou a diminuir e assim seguiu atē a maturação dos frutos. Certamente a drāstica redução das 


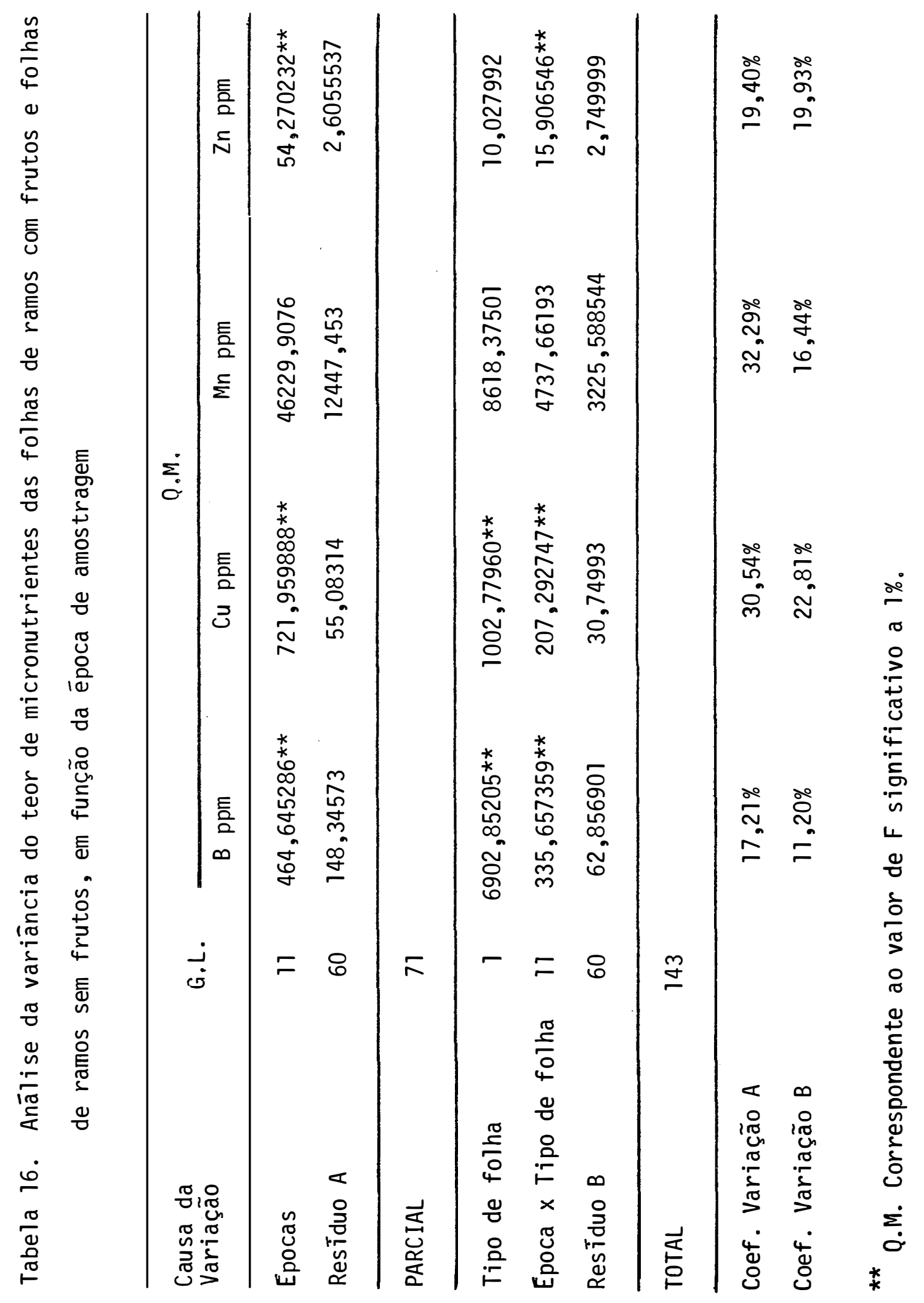




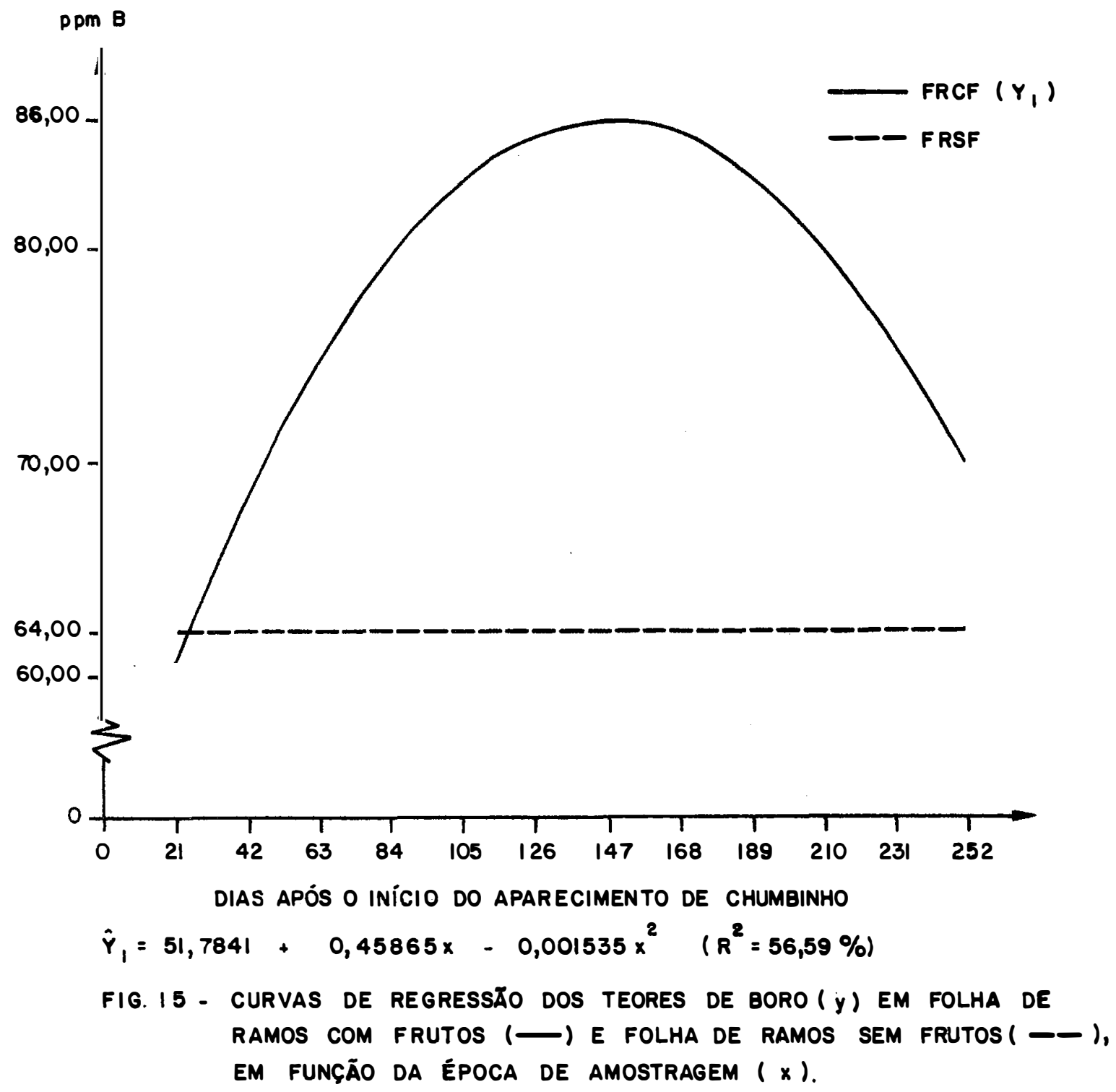


chuvas e o abaixamento da temperatura com consequente menor mineralização da matéria orgānica, são os fatores principais da redução da concentração de boro, no perĩodo.

Jā nas folhas de ramos sem produção, curiosamente os teores se mantiveram estāveis durante todo o periodo de desenvolvimento e maturação dos frutos. Provavelmente este tipo de folha não se presta para ser utilizada em diagnose foliar.

CHAVERRI et alii (1957), na Costa Rica, estudando as variações mensais de boro nas folhas de 40 par em cafeeiros arábica, obser varam maior concentração no perĩodo de maior quantidade de chuvas.

LOTT et alii (1961), fazendo um levantamento de cafezais em São Paulo e Paranā pela anālise foliar, citam teores médios de boro (B) de 60 ppm, 76 ppm e 135 ppm no verão (inîcio de formação dos frutos); outono (desenvolvimento dos frutos e maturação) e primavera (florescimento), respectivamente no Estado de São Paulo. Para o Estado do Paranā, estas concentrações foram de 69 ppm, 76 ppm e 76 ppm.

\subsection{Cobre}

\subsubsection{Concentração}

Os valores da concentração de cobre dos frutos, das foThas de ramos com frutos e das folhas de ramos sem frutos, em função da época de amostragem acham-se na Tabela 17. 
Tabela 17. Concentração (ppm) de cobre dos frutos, das folhas de ramos com frutos e das folhas de ramos sem frutos, em função da ēpoca de amostragem (mëdia de 6 repetições)

\begin{tabular}{|c|c|c|c|c|c|}
\hline \multirow[t]{2}{*}{ Epoca* } & \multirow{2}{*}{ Frutos } & \multicolumn{4}{|c|}{ Folhas } \\
\hline & & Ramos & com frutos & Ramos & sem frutos \\
\hline 21 & 30 & & 18 & & 15 \\
\hline 42 & 23 & & 14 & & 13 \\
\hline 63 & 21 & & 17 & & 14 \\
\hline 84 & 22 & & 44 & & 30 \\
\hline 105 & 19 & & 33 & & 42 \\
\hline 126 & 17 & & 33 & & 19 \\
\hline 147 & 17 & & 35 & & 14 \\
\hline 168 & 17 & & 22 & & 24 \\
\hline 189 & 17 & & 28 & & 19 \\
\hline 210 & 15 & & 19 & & 19 \\
\hline 231 & 15 & & 26 & & 26 \\
\hline 252 & 15 & & 32 & & 24 \\
\hline d.m.s. (Tukey 5\%) & 3,9 & & 12,7 & & 12,7 \\
\hline
\end{tabular}


A anālise da variância da concentração de cobre dos frutos, em função do seu desenvolvimento, encontra-se exposta na Tabela 15, verificando-se que a concentração foi afetada pela época.

Aos teores de cobre dos frutos, ajustou-se uma equação de regressão cúbica, mostrada na Figura 16, com os teores diminuindo de um māximo de 29 ppm aos 21 dias para um mīnimo de 15 ppm aos 252 dias apōs o inīcio do aparecimento de "chumbinho", sendo o ponto de inflexão situado aos 181 dias com concentração de 16 ppm.

CATANI et alii (1967b), verificando a variação na concentração de macro e micronutrientes dos frutos do cafeeiro, durante o seu desenvolvimento, constataram que o teor de Cu diminuiu de $25 \mathrm{ppm}$ no inîcio do desenvolvimento até $15 \mathrm{ppm}$ na fase de maturação. Estes resultados estão de acordo com os obtidos no presente trabalho.

Com relação às folhas, a anālise da variāncia da concentração de cobre das folhas de ramos com frutos e das folhas de ramos sem frutos, em função da época de amostragem pode ser vista na Tabela 16. A concentração de cobre foi afetada pela época e pelo tipo de folha com in teração.

Os teores de cobre das folhas de ramos com frutos, variaram segundo uma equação de regressão cúbica, mostrada na Figura 17, onde as concentrações aumentaram de 11 ppm aos 21 dias para um máximo de 33 ppm aos 103 dias após o inīcio do aparecimento de "chumbinho". Posteriormente os teores começaram a diminuir atē atingir 25 ppm aos 210 dias, com ponto de inflexão aos 156 dias e concentração de 29 ppm. 


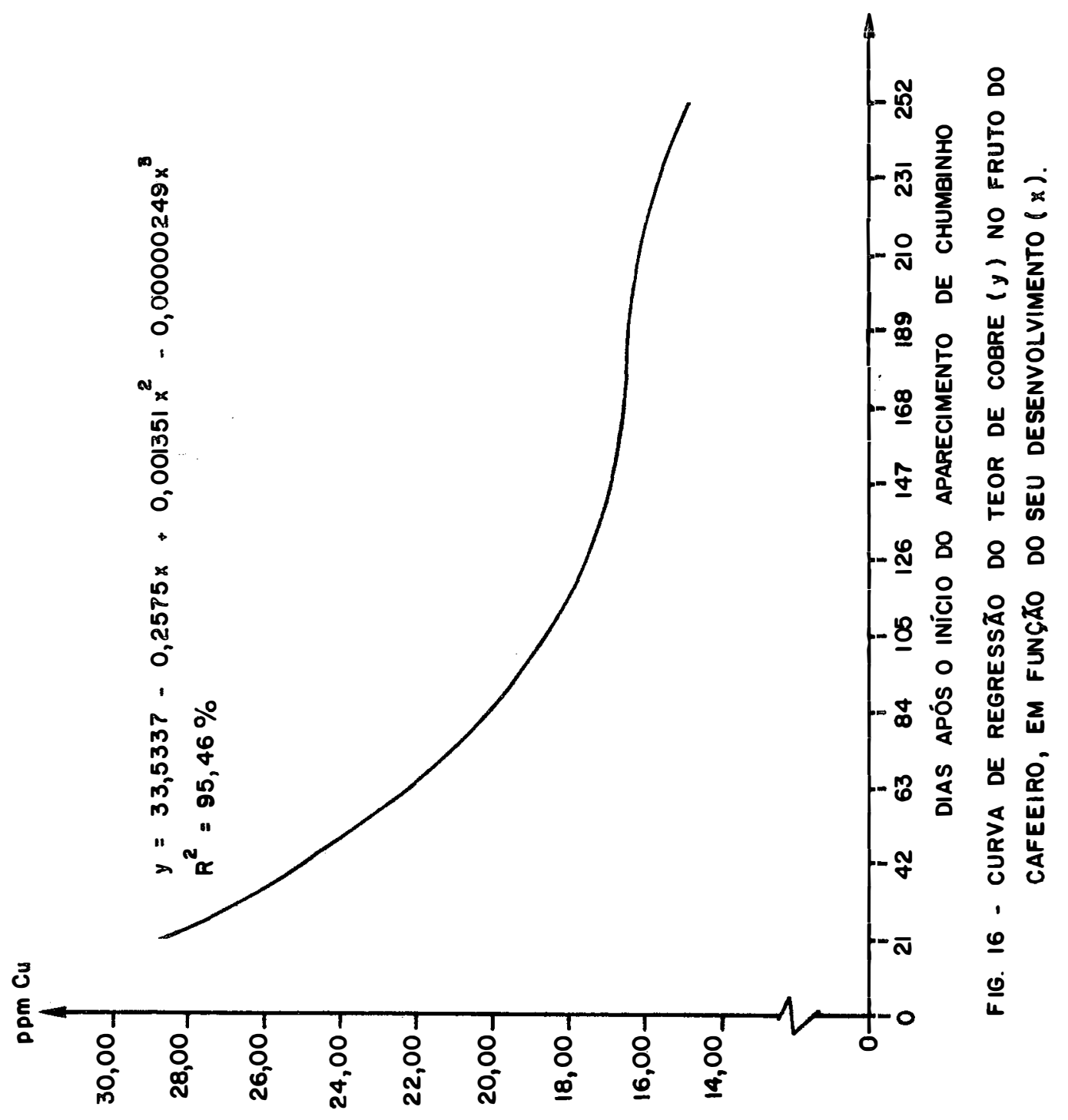




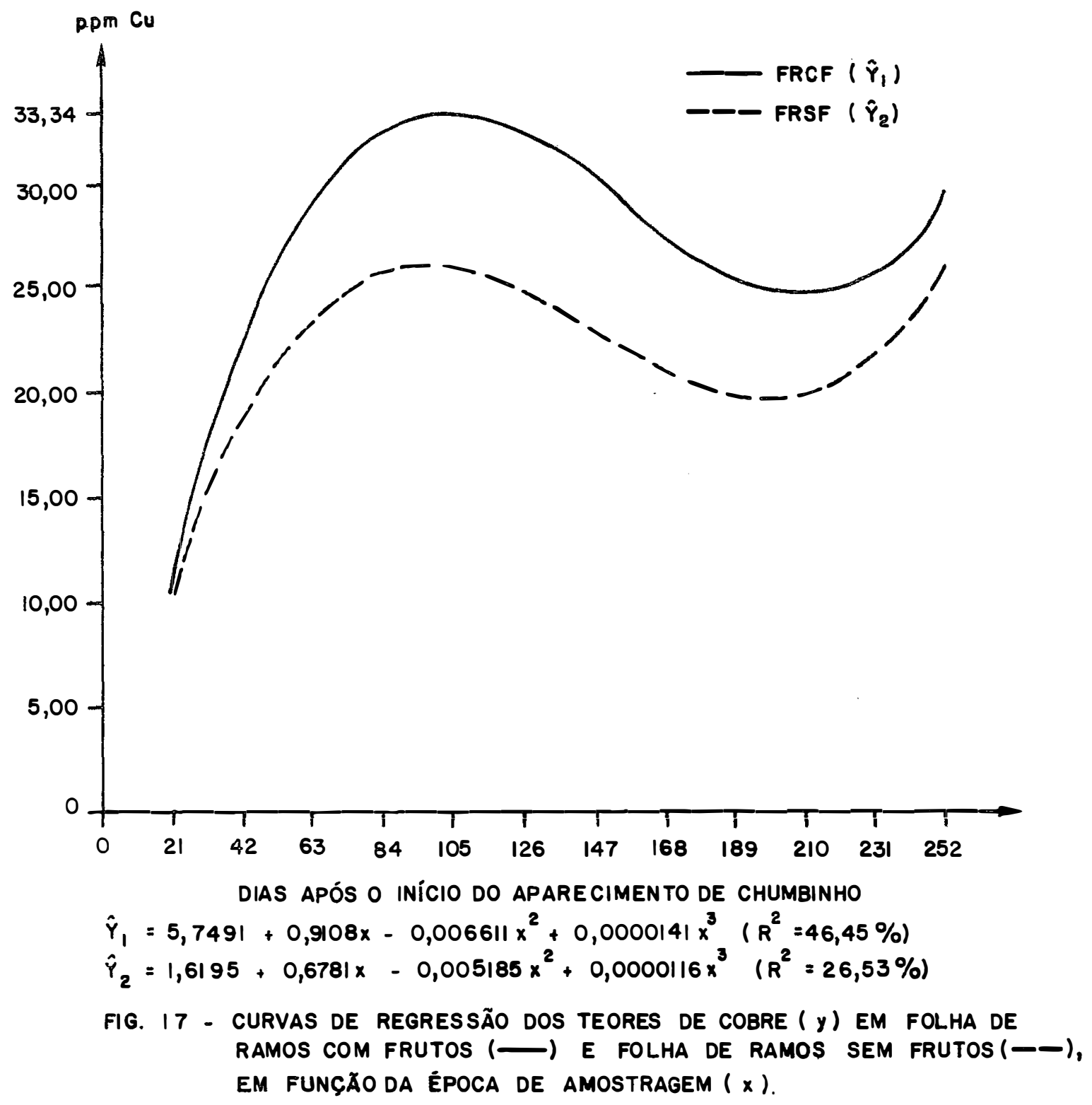


Nas folhas de ramos sem frutos, aos teores de cobre ajustou-se igualmente uma equação de regressão cübica, conforme a Figura 17 , com os teores aumentando de 10 ppm aos 21 dias até um máximo de 26 ppm aos 97 dias apōs o inīcio do aparecimento de "chumbinho" e decrescendo atē 20 ppm aos 200 dias com ponto de inflexão aos 149 dias e concentração de 23 ppm.

A variação na concentração de cobre nos dois tipos de foThas foi muito semelhante ao longo do desenvolvimento dos frutos porém, em média, o teor do elemento foi mais elevado nas folhas de ramos com frutos.

LOTT et alii (1961), realizando um levantamento de cafezais do Estado de São Paulo e Paraná pela anālise foliar, citam teores médios de Cu de 11,9 ppm; 10,8 ppm e 14,2 ppm no verão (inīcio de formação dos frutos); outono (desenvolvimento dos frutos e maturação) e primavera (florescimento) respectivamente no Estado de São Paulo. Para o Estado do Paranā estas concentrações foram de 16,7 ppm; 15,6 ppm e 22,1 ppm.

BONNET (1969), amostrando folhas de cafeeiros Caturra e Bourbon Vermelho no estādio de desenvolvimento dos frutos (final de verão) e no final do inverno, constatou teores de cobre semelhantes nas duas épocas. 


\subsection{Manganês.}

\subsubsection{Concentração}

Ds valores da concentração de manganès dos frutos, das folhas de ramos com frutos e das folhas de ramos sem frutos, em função da época de amostragem, acham-se na Tabela 18.

A anālise da variāncia da concentração de manganēs dos frutos, em função do seu desenvolvimento, encontra-se exposta na Tabela 15, verificando-se que a concentração foi afetada pela época.

Aos teores de manganês, dos frutos, ajustou-se uma equa ção de regressão cúbica, mostrada na Figura 18, com os teores diminuindo de 208 ppm para um mīnimo de 42 ppm dos 21 aos 142 dias após o inīcio do aparecimento de "chumbinho". Posteriormente, as concentrações aumentaram levemente até aos 216 dias com concentração de 52 ppm. 0 ponto de inflexão se situou aos 179 dias com concentração de 47 ppm.

CATANI et alii (1967b), verificando a variação na concentração de macro e micronutrientes dos frutos do cafeeiro, durante 0 seu desenvolvimento, encontraram que o teor de Mn diminuiu de 128 ppm na fase inicial de formação do fruto, atē 35 ppm no perīodo de maturação. 
Tabela 18. Concentração (ppm), de manganēs dos frutos, das folhas de ra mos com frutos e das folhas de ramos sem frutos, em função da época de amostragem (mēdia de 6 repetições)

\begin{tabular}{cccc}
\hline Epoca* & Frutos & \multicolumn{2}{c}{ Folhas } \\
\cline { 3 - 4 } & & Ramos com frutos & Ramos sem frutos \\
\hline 21 & 240 & 380 & 385 \\
42 & 104 & 321 & 305 \\
63 & 66 & 368 & 290 \\
84 & 98 & 420 & 364 \\
105 & 71 & 331 & 362 \\
126 & 49 & 265 & 231 \\
147 & 49 & 319 & 255 \\
168 & 38 & 270 & 297 \\
1899 & 44 & 387 & 370 \\
210 & 48 & 419 & 438 \\
231 & 38 & 326 & 285 \\
252 & 56 & 431 & 470 \\
\hline d.m.s. (Tukey 5\%) & 50 & & 172 \\
\hline
\end{tabular}

Dias apōs o inīcio do aparecimento de "chumbinho". 


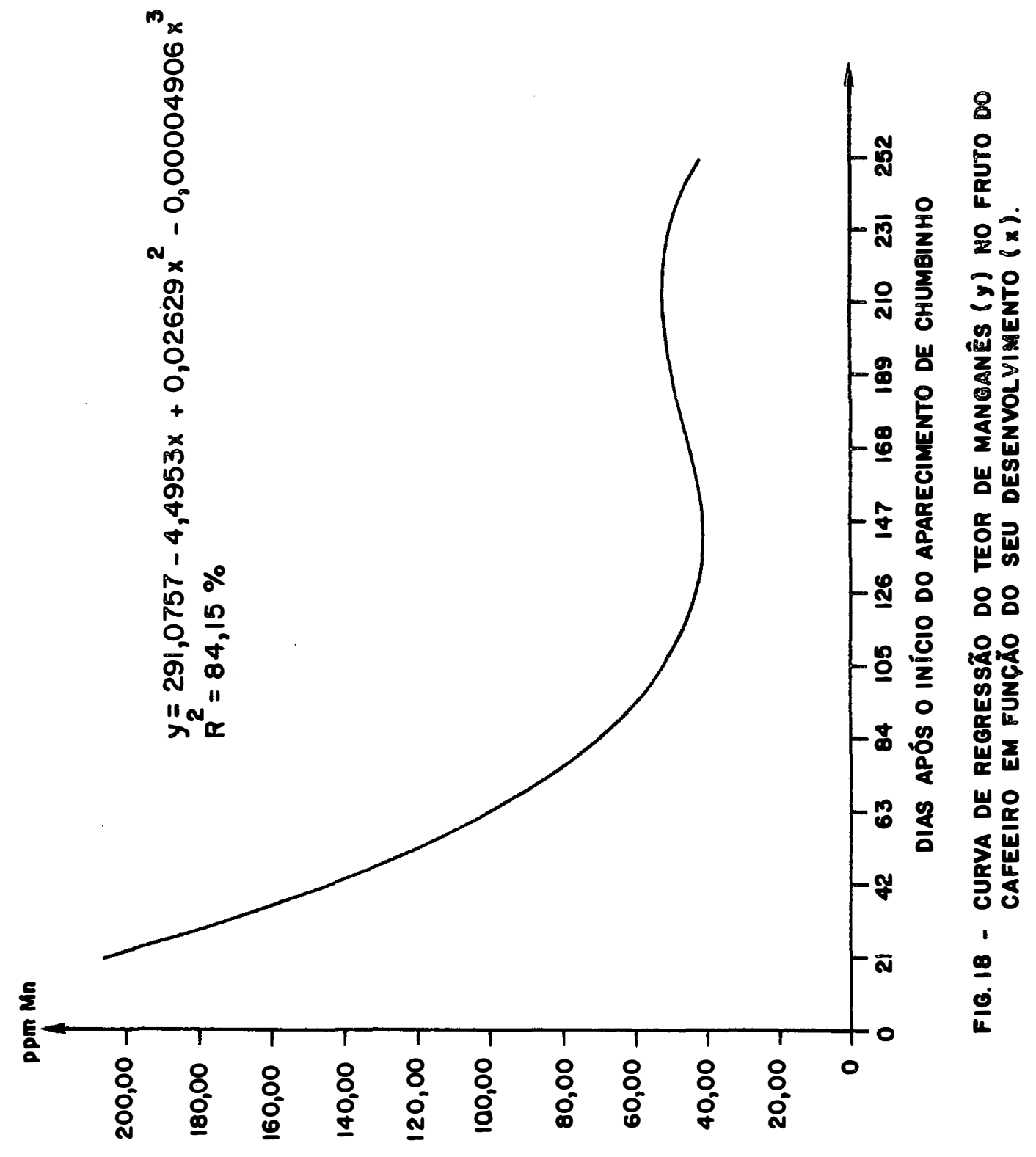


SILVA e SOUZA et alii (1975), estudando a variação de alguns elementos minerais nos frutos do cafeeiro, observaram que os teores de manganēs encontrados permaneceram praticamente constantes durante todo o período de frutificação. Estes resultados diferem completamente dos obtidos no presente trabalho.

Com relação às folhas, a anālise da variância da concentração de manganês das folhas de ramos com frutos e das folhas de ramos sem frutos, em função da época de amostragem, pode ser vista na Tabe1a 16. A concentração de manganēs foi afetada pela época.

Os teores de manganès das folhas de ramos com frutos, variaram segundo uma equação de regressão quadrātica, mostrada na Figura 19, onde as concentrações decresceram a princípio de 386 ppm para um mínimo de 323 ppm dos 21 aos 127 dias após o início do aparecimento de "chumbinho". Posteriormente a este período, os teores aumentaram.

Nas folhas de ramos sem frutos, aos teores de manganēs ajustou-se igualmente uma equação de regressão quadrātica conforme a $\mathrm{Fi}$ gura 19, com os teores diminuindo de 370 ppm para um mínimo de 294 ppm dos 21 aos 124 dias após o início do aparecimento "chumbinho". Posteriormente a este perĩodo, as concentrações começaram a aumentar.

Estatisticamente o comportamento das folhas de ramos sem frutos não diferiu das folhas de ramos com frutos.

LOTT et alii (1961), realizando um levantamento de cafezais do Estado de São Paulo e Paraná, pela anālise foliar, citam teores médios de Mn de 138 ppm; 162 ppm e 139 ppm no verão (inīcio de formação 


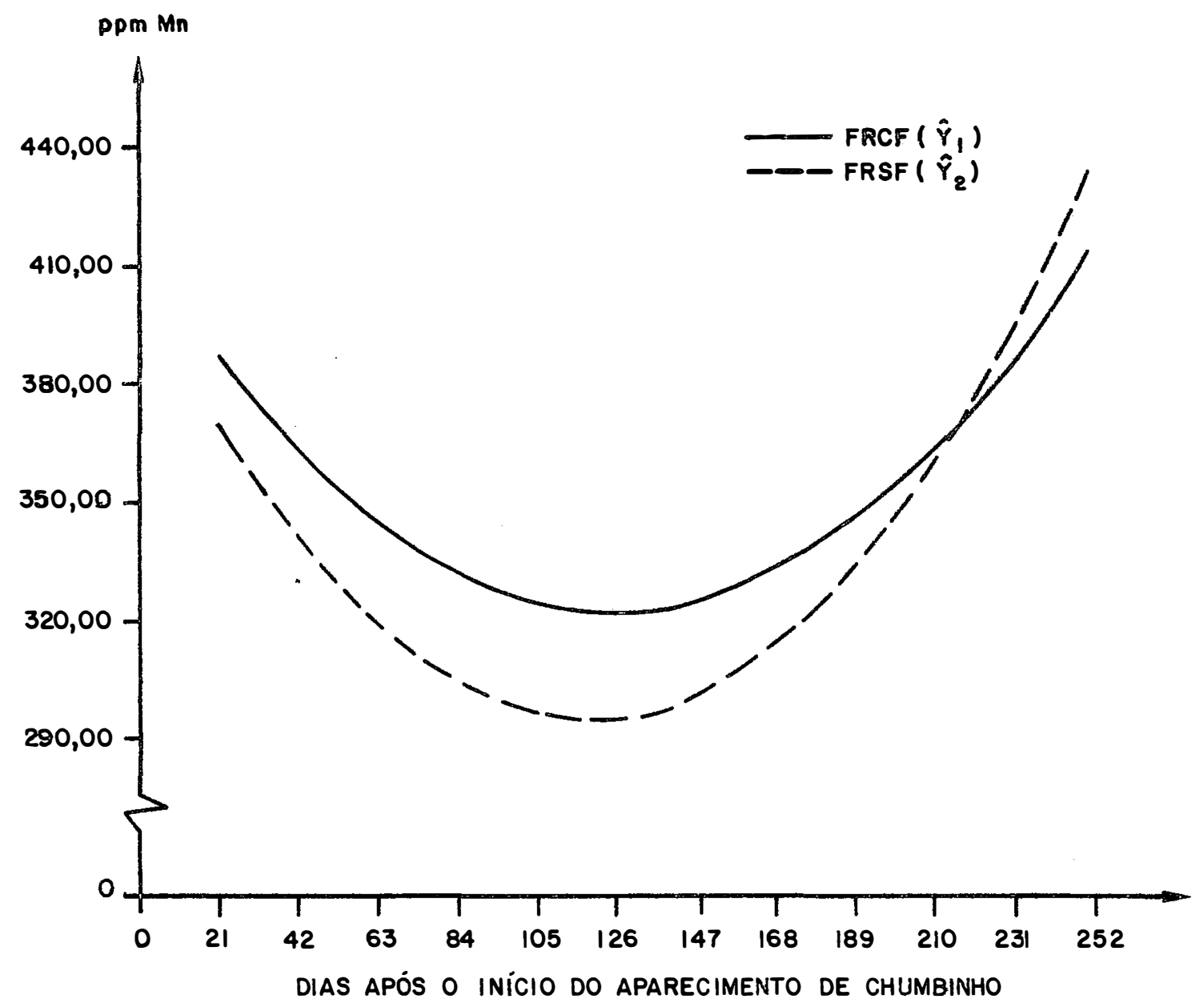

$\hat{Y}_{1}=413,8410-1,43758 x+0,0056759 x^{2} \quad\left(R^{2}=25,94 \%\right)$

$\hat{Y}_{2}=405,9166-1,88260 x+0,0079029 x^{2} \quad\left(R^{2}=36,07 \%\right)$

FIG.19 - CURVAS DE REGRESSÃO DOS TEORES DE MANGANÊS $(y)$ EM FOLHA DE RAMOS COM FRUTOS (-) E FOLHA DE RAMOS SEM FRUTOS (- - ), EM FUNÇĀO DA ÉPOCA DA AMOSTRAGEM $(x)$. 
dos frutos); outono (desenvolvimento dos frutos e maturação e primavera (florescimento), respectivamente no Estado de São Paulo. Para o Estado do Paranā estas concentrações foram de 139 ppm; 200 ppm e 250 ppm,

SILVA e SOUZA et alii (1975), estudando a variação de alguns elementos minerais nas folhas do cafeeiro, observaram uma tendēncia ascencional para os teores de manganēs, à medida do desenvolvimento dos frutos.

\subsection{Zinco}

\subsubsection{Concentração}

Os valores da concentração de zinco dos frutos, das foThas de ramos com frutos e das folhas de ramos sem frutos, em função da época de amostragem, acham-se na Tabela 19.

A anālise da variāncia da concentração de zinco dos frutos, em função do seu desenvolvimento, encontra-se exposta na Tabela 18, verificando-se que a concentração foi afetada pela época.

Aos teores de zinco dos frutos, ajustou-se uma equação de regressão cúbica, mostrada na Figura 20, com os teores diminuindo de 15 ppm para 4 ppm dos 21 aos 252 dias após o inĩcio do aparecimento de "chumbinho", com ponto de inflexão aos 216 dias com concentração de 4,2 ppm. 
Tabela 19. Concentração (ppm) de zinco dos frutos, das folthas de ramos com frutos e das folhas de ramos sem frutos, em função da ēpoca de amostragem (média de 6 repetições)

\begin{tabular}{|c|c|c|c|c|}
\hline \multirow{2}{*}{ Epoca* } & \multirow{2}{*}{ Frutos } & \multicolumn{3}{|c|}{ Folhas } \\
\hline & & Ramos & com frutos & Ramos sem frutos \\
\hline 21 & 16 & & 11 & 10 \\
\hline 42 & 10 & & 8 & 7 \\
\hline 63 & 10 & & 7 & 5 \\
\hline 84 & 8 & & 8 & 8 \\
\hline 105 & 7 & & 6 & 11 \\
\hline 126 & 5 & & 13 & 10 \\
\hline 147 & 5 & & 10 & 10 \\
\hline 168 & 5 & & 9 & 11 \\
\hline 189 & 4 & & 11 & 7 \\
\hline 210 & 4 & & 5 & 5 \\
\hline 231 & 4 & & 5 & 5 \\
\hline 252 & 4 & & 9 & 7 \\
\hline d.m.s. (Tukey 5\%) & 2,3 & & 3,0 & 3,0 \\
\hline
\end{tabular}




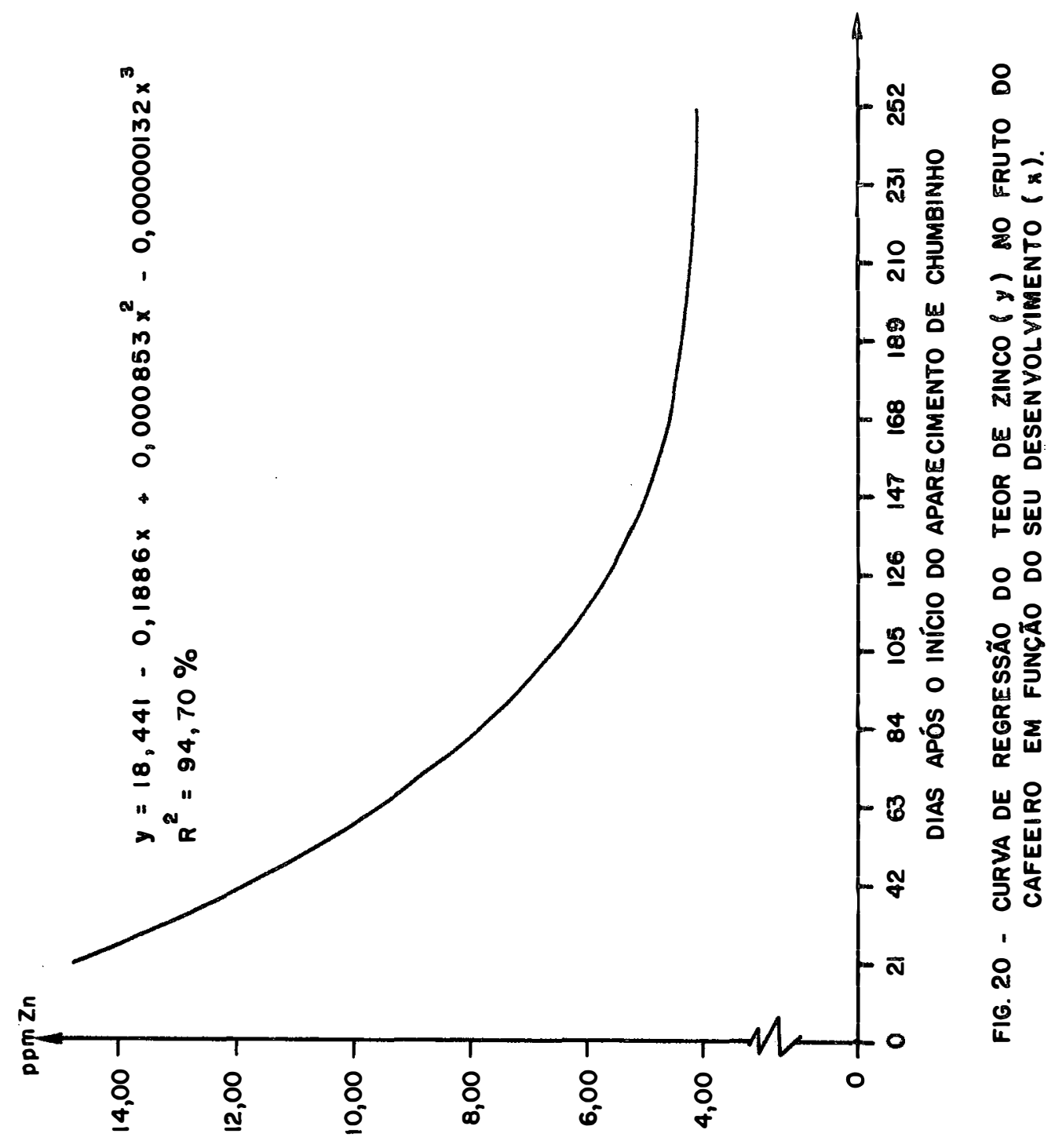


CATANI et alii (1967b), verificando a variação na concen tração de macro e micronutrientes dos frutos do cafeeiro, durante o seu desenvolvimento, constataram que o teor de $\mathrm{Zn}$ diminuiu de $11 \mathrm{ppm}$ na fase inicial de formação do fruto atē 3 ppm no perīodo de maturação. No presente trabalho, os valores estiveram muito próximos a esses.

SILVA e SOUZA et alii (1975), estudando a variação de alguns elementos minerais nos frutos do cafeeiro, observaram que os teores de zinco encontrados foram mais ou menos constantes, em sua fase inicial de crescimento, caindo da $\bar{i}$ em diante.

Com relação às folhas, a anālise da variância da concentração de zinco das folhas de ramos com frutos e das folhas de ramos sem frutos, em função da época de amostragem, pode ser vista na Tabela 16. A concentração de zinco foi afetada pela época interagindo com tipo de foTha.

Os teores de zinco das folhas de ramos com frutos variaram segundo uma equação de regressão cübica, mostrada na Figura 21, onde as concentrações decresceram de 10 ppm para 8 ppm dos 21 aos 83 dias após o inĩcio do aparecimento de "chumbinho". Apōs este período os teores aumentaram atē aos 172 dias com 9 ppm voltando a diminuir em seguida. 0 pon to de inflexão se situou aos 128 dias com 9 ppm.

Nas folhas de ramos sem frutos, aos teores de zinco ajustou-se uma equação de regressão quadrātica, conforme a Figura 21 com os teores aumentando de 8 ppm para um máximo de 9 ppm dos 21 aos 112 dias apōs o inīcio do aparecimento de "chumbinho". Após este perīodo os teores diminuiram atē aos 252 dias quando atingiram $6 \mathrm{ppm}$. 


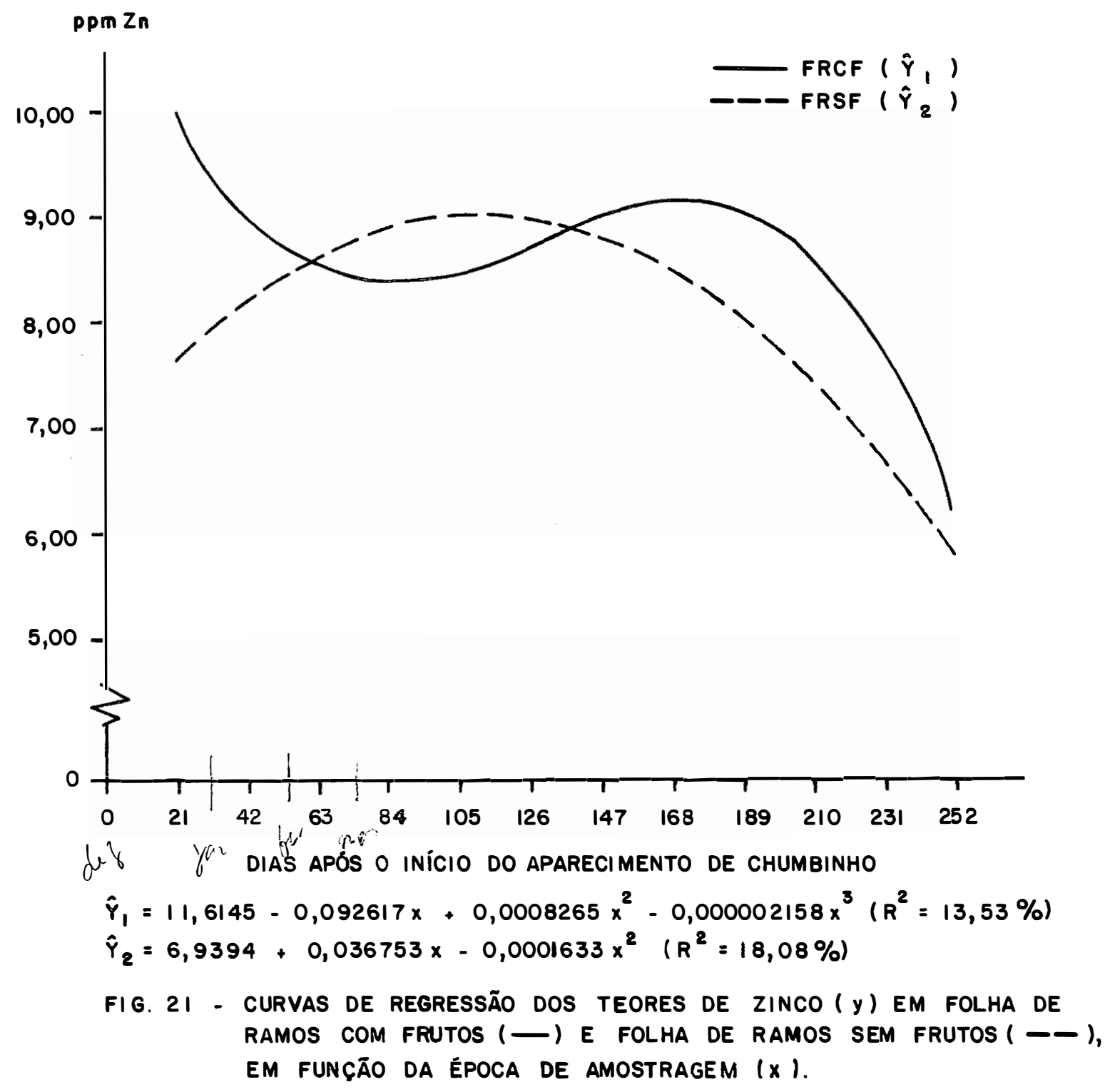


A variação na concentração de zinco nos dois tipos de folhas foi distinta ao longo do desenvolvimento dos frutos, porém em mëdia, o teor do elemento foi ligeiramente mais elevado nas folhas de ramos com frutos.

LOTT et alii (1961), realizando um levantamento de cafezais, no Estado de São Paulo e Paraná, pela anālise foliar, citam teores médios de $\mathrm{Zn}$ de $11,6 \mathrm{ppm} ; 13,5 \mathrm{ppm}$ e $9,3 \mathrm{ppm}$ no verão (início de formação dos frutos), outono (desenvolvimento dos frutos e maturação) e primavera (florescimento), respectivamente no Estado de São Paulo. Para o Estado do Paranā estas concentrações foram de 22,6 ppm; 15,0 ppm e 19,1 ppm.

$$
\text { SILVA e SOUZA et alii (1975), estudando a variação de }
$$
alguns elementos minerais nas folhas do cafeeiro, observaram um crescimento na concentração de zinco no perỉodo inicial de desenvolvimento dos frutos, seguido de um decréscimo. Estes resultados coincidem com os obti dos no presente trabalho para folhas de ramos sem produção.

\subsection{Extração dos Nutrientes}

Na Tabela 20 encontram-se as quantidades de macronutrien tes e matéria seca nos frutos do cafeeiro na época de máximo acūmulo.

A extração total de macronutrientes pelos frutos do cafeeiro em ordem decrescente em $\mathrm{Kg} / \mathrm{ha}$ foi: potāssio 127,390; nitrogênio 93,420; cālcio 10,190; magnésio 8,920; enxofre 6,990 e fósforo 4,360.

Verifica-se pela Tabela 20 a grande exportação de potāssio e nitrogênio pelos frutos e a pequena exportação de fósforo. 
Tabela 20. Quantidades de macronutrientes acumuladas e matéria seca produzida pelos frutos do cafeeiro nas épocas (dias entre parēnteses) de māximo acūmulo

\begin{tabular}{lrr}
\hline \multirow{2}{*}{ Macronutrientes } & \multicolumn{2}{c}{ Frutos } \\
\cline { 2 - 3 } Nitrogēnio & $93,42(210)$ & $\mathrm{kg} / \mathrm{hal}$ \\
Fösforo & $4,36(252)$ & 93,420 \\
Potāssio & $127,39(210)$ & 4,360 \\
Cálcio & $10,19(210)$ & 127,390 \\
Magnésio & $8,92(210)$ & 10,190 \\
Enxofre & $6,99(252)$ & 8,920 \\
Matéria Seca & $4.251,46(217)$ & 6,990 \\
& & $4,251,460$ \\
\hline
\end{tabular}

1 Calculado em função de 1000 covas (2 plantas/cova).

As épocas de máximo acúmulo de macronutrientes nos frutos oscilou entre 210 a 252 dias.

Na Tabela 21, verificam-se os valores de extração de macronutrientes ( $\mathrm{g} /$ cova e percentagem do total absorvido), durante 0 desenvolvimento dos frutos.

As quantidades de boro, cobre, manganês e zinco nos frutos do cafeeiro na época de máximo acúmulo podem ser vistas na Tabela 22. 


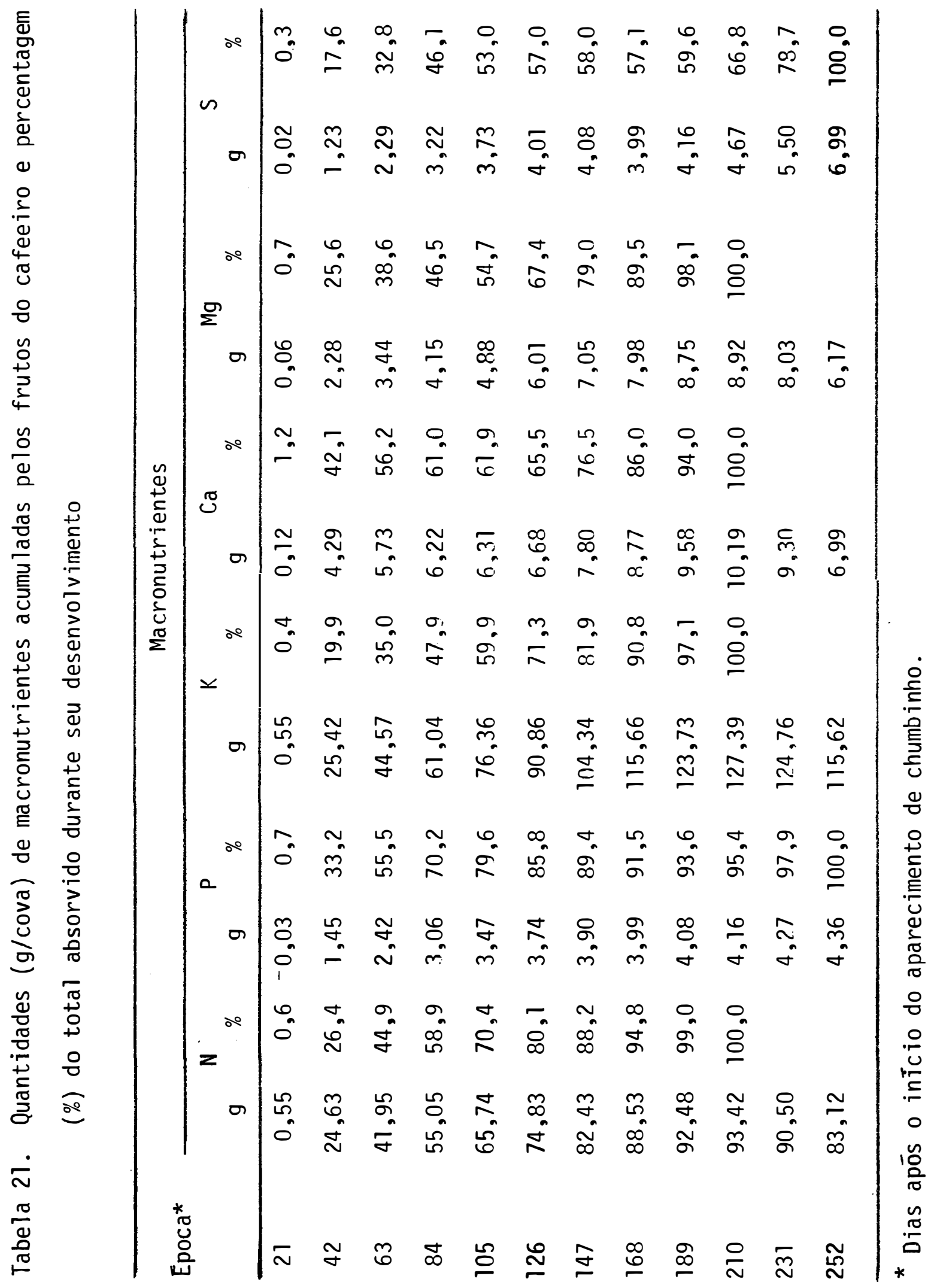


Tabela 22. Quantidades de micronutrientes acumuladas e matéria seca produzida pelos frutos do cafeeiro nas épocas (dias entre parēnteses) de máximo acúmulo.

\begin{tabular}{lrc}
\hline \multirow{2}{*}{ Micronutrientes } & \multicolumn{2}{c}{ Frutos } \\
\cline { 2 - 3 } & $71,90(231)$ & $\mathrm{g} / \mathrm{ha}^{\mathrm{l}}$ \\
\hline Boro & $67,94(210)$ & 71,900 \\
Cobre & $220,80(210)$ & 67,940 \\
Manganês & $20,04(126)$ & 220,800 \\
Zinco & $4.251,46^{2}(217)$ & 20,040 \\
Matéria Seca & & $4.251,460^{3}$ \\
\hline
\end{tabular}

1 Calculado em função de 1000 covas (2 plantas/cova)

2 Calculado em g/cova

3 Calculado em $\mathrm{kg} / \mathrm{ha}$

A extração total destes micronutrientes em ordem decrescente em g/ha foi: manganês 220,800; boro 71,900; cobre 67,940 e zinco 20,040 .

Os acūmulos máximos dos micronutrientes estudados nos frutos, ocorreram entre 126 e 231 dias.

Na Tabela 23, verificam-se os valores de extração (mg/co va e percentagem do total absorvido), durante o desenvolvimento dos frutos. 
Tabela 23. Quantidades(mg/cova) de micronutrientes acumuladas pelos frutos do cafeeiro e percentagem $(\because)$ do total absorvido durante seu desenvolvimento

\begin{tabular}{lrrrrrrrrr}
\hline & \multicolumn{7}{c}{ Micronutrientes (mg/cova) } \\
\cline { 2 - 10 } & \multicolumn{1}{c}{$\mathrm{mg}$} & $\%$ & $\mathrm{mg}$ & $\%$ & $\mathrm{mg}$ & $\%$ & $\mathrm{mg}$ & $\%$ \\
\hline 21 & 0,72 & 1,0 & 0,50 & 0,7 & 3,59 & 1,5 & 0,26 & 1,3 \\
42 & 26,30 & 36,6 & 21,92 & 32,3 & 127,12 & 57,6 & 10,52 & 52,5 \\
63 & 34,40 & 47,8 & 36,05 & 53,1 & 163,87 & 74,2 & 16,39 & 81,8 \\
84 & 34,55 & 48,0 & 46,07 & 67,8 & 161,24 & 73,0 & 18,43 & 92,0 \\
105 & 34,45 & 47,9 & 51,67 & 76,0 & 149,28 & 67,6 & 17,22 & 85,9 \\
126 & 36,75 & 51,1 & 60,13 & 88,5 & 146,99 & 66,6 & 20,04 & 100,0 \\
147 & 40,84 & 56,8 & 63,12 & 92,9 & 159,67 & 72,3 & 18,57 & \\
168 & 51,85 & 72,1 & 67,80 & 99,8 & 179,47 & 81,3 & 19,94 & \\
189 & 62,50 & 86,9 & 66,65 & 98,1 & 204,13 & 92,4 & 16,67 & \\
210 & 67,94 & 94,5 & 67,94 & 100,0 & 220,80 & 100,0 & 16,98 & \\
231 & 71,90 & 100,0 & 63,44 & & 215,69 & & 16,92 & \\
252 & 69,95 & & 61,72 & & 176,94 & & 16,46 & \\
\hline
\end{tabular}

Dias apōs o inīcio do aparecimento de "chumbinho". 


\section{CONCLUSŌES}

\subsection{Desenvolvimento dos Frutos}

- A produção de matéria seca pelos frutos foi contīnua atē aos 217 dias quando atingiu o ponto de máximo acúmulo com $4.251,46 \mathrm{~g} / \mathrm{co-}$ va (2 plantas).

\subsection{Concentração de Nutrientes.}

- As concentrações de $\mathrm{N}, \mathrm{P}, \mathrm{K}, \mathrm{Ca}, \mathrm{Mg}, \mathrm{B}, \mathrm{Cu}, \mathrm{Mn}$ e $\mathrm{Zn}$ foram mais elevadas nos frutos, nos seus estādios iniciais de crescimento.

- As concentrações de $S$ foram mais elevadas nos frutos, nos seus estādios finais de maturação.

- 0 comportamento do N, P, B e Zn ao longo do desenvolvimento dos frutos, foi diferente quando se analisaram folhas de ramos com frutos e folhas de ramos sem frutos.

- 0 comportamento do $\mathrm{K}, \mathrm{Ca}, \mathrm{Mg}, \mathrm{S}, \mathrm{Cu}$ e $\mathrm{Mn}$, ao longo do desenvolvimento dos frutos, foi semelhante quando se analisaram folhas de ramos com frutos e folhas de ramos sem frutos. 
- As folhas de ramos com frutos apresentaram teores mais elevados de N, P, K, Mn e Zn nos estádios iniciais de crescimento dos fru tos e concentrações mais baixas de $\mathrm{Ca}, \mathrm{Mg}, \mathrm{S}, \mathrm{B}$ e $\mathrm{Cu}$ nessa mesma época.

- As folhas de ramos sem frutos apresentaram teores mais elevados de $P, K$ e Mn no início de formação dos frutos e concentrações mais baixas em $\mathrm{N}, \mathrm{Ca}, \mathrm{Mg}, \mathrm{S}$, Cu e $\mathrm{Zn}$ nessa mesma época.

- A concentração de B nas folhas de ramos sem frutos permaneceu estāvel, durante todo o período de crescimento dos frutos.

\subsection{Diagnose Foliar,}

- A avaliação do estádo nutricional do cafeeiro para os elementos N, P, B e $Z$ n deve ser feita utilizando as folhas de ramos com frutos.

- A avaliação do estado nutricional do cafeeiro em K, Ca, $\mathrm{Mg}, \mathrm{S}$, Cu e Mn pode ser feita utilizando-se tanto folhas de ramos com frutos como folhas de ramos sem frutos.

\subsection{Redistribuição de Nutrientes.}

- Ocorreu redistribuição de nutrientes tanto de folhas de ramos com frutos quanto de folhas de ramos sem frutos.

- A redistribuição de $N, P, K$ e $M n$ foi mais acentuada na época de maior desenvolvimento dos frutos e para o $\mathrm{N}$ e P, ocorreu com maior intensidade das folhas de ramos com frutos. 
5.5. Extraç̧ão de Nutrientes.

- 0 acúmulo máximo de nutrientes pelos frutos oscilou entre 210 a 252 dias, com exceção do zinco que ocorreu aos 126 dias, apōs o início do aparecimento de "chumbinho".

- A extração total de nutrientes pelos frutos obedeceu à seguinte ordem decrescente: potāssio, nitrogēnio, cālcio, magnēsio, enxofre, fósforo, manganēs, boro, cobre e zinco. 
ADUAYI, E.A., 1971. The effect of copper on the growth and major nutrient contents of coffe seedlings grown in nutrient solutions. Turrialba, 21 $(1): 53-57$.

AMORIN, H.V.de; L.C.SCOTON; A.CASTILHO; F.P.GOMES e E.MPLAVOLTA, 1965. Es tudos sobre a alimentação mineral do cafeeiro. XVII. Efeito da adubação NPK na composição quîmica do solo, do fruto e na qualidade da bebida (Nota preliminar). Anais da Escola Superior de Agricultura "Luiz de Queiroz", Piracicaba, 22:139-151.

AMORIN, H.V.de; L.C.SCOTON; A.CASTILHO; F.P.GOMES e E.MALAVOLTA, 1967. ES tudos sobre a alimentação mineral do cafeeiro. XXI. Efeito da adubação $N, P, K$ e orgānica na composição mineral do grão e na qualidade da bebida (2a. nota). Anais da Escola Superior de Agricultura "Luiz de Queiroz", Piracicaba, 24:215-227.

AMORIN, H.V.de; L.C.SCOTON; H.P.HAAG e E.MALAVOLTA, 1968. Estudos sobre a alimentação mineral do cafeeiro. XX. Efeito da variação do pH no desenvolvimento e composição quīmica do cafeeiro (Cobfea arabica L. var. Mundo Novo) cultivado em Solução Nutritiva. Anais da Escola Superior, de Agricultura "Luiz de Oueiroz", Piracicaba, 25:121-135. 
AMORIN, H.V.de; A.A.TEIXEIRA; R.S.MORAES; A.J.REIS; F.P.GOMES e E. MALAVOLTA, 1973. Estudos sobre a alimentação Mineral do Cafeeiro, XXVII. Efeito da adubação N, P e K no teor de macro e micronutrientes do fruto e na qualidade da bebida do café. Anais da Escola Superior de Agricultura "Luiz de Queiroz", Piracicaba, 30:323-333.

ANSTEAD, R.E. e C.K.PITTOCK, 1913. The varying composition of the Coffee berry at different stages of its growth and its relation to the manuring of coffee estates. Planters' chornicle, Coimbatore, $\underline{8}(36): 455-460$.

ARISTIZABAL, G.V. e J.A.PULGARIN, 1977. Efecto de la fertilization con $\mathrm{N}, \mathrm{P}, \mathrm{K}$ a tres niveles en la composicion mineral de las hojas del cafe to. Cenịcafé, Chinchina, 28(4):119-138.

ARZOLLA, J.D.P., 1955. Contribuição ao estudo da absorção e da translocação do radio-zinco no cafeeiro. Piracicaba, ESALQ/USP, 38 p. (Tese de Doutoramento) .

ARZOLLA, J.D.P.; H.P.HAAG e E.MALAVOLTA, 1955/1956. Nota preliminar sobre a absorção e a translocação do radiozinco no cafeeiro lCobfea arabica) cultivado em solução nutritiva. Anais da Escola Superior de Agricultura "Luiz de Queiroz", Piracicaba, 12/13:113-120.

ARZOLLA, S.; L.GOMES; J.R.SARRUGE; R.G.ANDRADE; E.A.GRANER e E.MALAVOLTA, 1963. Estudos sobre a alimentação mineral do cafeeiro. X. Extração de macronutrientes na colheita pelas variedades "Mundo Novo", "Caturra" e "Bourbon Amarelo". Anais da Escola Superior de Agricultura "Luiz de Queiroz", Piracicaba, 20:41-52.

AVILAN, L., 1971. Variaciones de los niveles de nitrogeno, fósforo, potassio y calcio en las hojas de mango (Mangifera indica Linn.) a traves de un ciclo de producciōn. Agronomia Tropical, Maracay, 21 (1):3-10. 
BATAGLIA, O.C.; O.RODRIGUEZ; R.HIROCE; J.R.GALLO; P.R.FURLAN e A.M.C.FURLANI, 1977. Composição mineral dos frutos cítricos na colneita. Bragantia, Campinas, 36(21):215-221.

BATES, T.E., 1971. Factors affecting critical nutrient concentration in plants and their evaluation: a review Soil Science, New Brunswick, 112:116-130.

BIDDULPH, 0., 1941. Diurnal migration of injected radiophosphorus from bean leaves. American Journal of Botany, Lancaster, 28(4):348-352.

BIDDULPH, 0. e J.MARKLE, 1944. Translocation of radiophosphorus in the phloem of the cotton plant. American Journal of Botany, Lancaster, 31 (1):65-70.

BIDDULPH, 0.; S.BIDDULPH; R.CORY e H.KOONTZ, 1958. Circulation patherns for phosphorus, sulfur and calcium in the bean plant. Plant Physiology, Lancaster, 33:293-300.

BONNET, J.A., 1969. Influence of varieties and seasons upon the mineral nutrient levels of Coffee leaves from Puerto Rico. Journal of Agriculture of the University of Puerto Rico, Rio Piedras, 53(3):177-186.

BRENCHLEY, W.E., 1929. The phosphate requirements of barley at different periods of growth. Annals of Botany, London, 43:89-110.

BROWN, A.L.; S.YAMAGUCHI e J.LEAL-DINIZ, 1965. Evidence for translocation of iron in plants. Plant Physiology, Lancaster, 40:35-38.

BUKOVAC, M. e S.H.WITTWER, 1957. Absorption and mobility of foliar applied nutrients. Plant Physiology, Lancaster, 32:428-435.

BURD, J.S., 1919. Rate of absorption of soil constituentes at sucessive stages of plant growth. Journal of Agricultural Research, Wasghinton, 18:51-72. 
CAHOON, G.A., 1980. Nutrient content of twelve french and American hybrid grope cultivars grown under a wide range of soil conditions. Research. circular, Ohio Agricultural Research and Development Center, Wooster, (259):39-48.

CANNELL, M.G.R. e P.A.HUXLEY, 1969, Seasonal differences in the pattern of assimilates movement in branches of Coffea arabica L., Annals of applied Biology, Cambridge, 64:345-357.

CANNELL, M.G.R. e B.S.KIMEU, 1971. Uptake and distribution of macronutrient in trees of Coffea arabica $L$. in Kenya as affected by seasonal climatic differences and the presence of fruits. Annals of applied, Biology, Cambridge, 68(2):213-230.

CARVAJAL, J.F.; A.ACEVEDO e C.A.LOPES, 1969. Nutrient uptake by the Coffee tree durign a yearly cycle. Turrialba, 19(1):13-20.

CASTRO, A.M.G.de; J.R.SARRUGE e 0.C.RIBEIRO, 1975. Extração e exportação de macronutrientes por frutos de Guaranā (Paullinia cupana var. Sorbilis) no municipio de Maues - AM. Anais da Escola Superior de Agricultura "Luiz de Queiroz", 32:609-614.

CATANI, R.A. e F.R.P.de MORAES, 1958. A composição quīmica do cafeeiro. Revista de Agricultura, Piracicaba, 33:45-52.

CATANI, R.A.; D.PELEGRINO; H.BERGAMIN FILHO; N.A.da GLORIA e C.A.F. GRANER, 1965. A absorção de nitrogênio, fósforo, potāssio, cālcio, magné sio e enxofre pelo cafeeiro, Cobfea arabica var. Mundo Novo ! (B.Rodr.) Choussy| aos dez anos de idade. Anais da Escola Superior de Agricultura "Luiz de Queiroz", Piracicaba, 22:81-93. 
CATANI,.R.A.; D.PELEGRINO; V.C.BITTENCOURT; A.O.JACINTHO e C.A.F. GRANER, 1967a. A concentração e a quantidade de micronutrientes e de alumīnio no cafeeiro, Cobfea arabica, L., variedade Mundo Novo (B.Rodr.)Choussy, aos dez anos de idade. Anais da Escola Superior de Agricultura "Luiz. de Queiroz", Piracicaba, 24:97-106.

CATANI, R.A.; D.PELEGRINO; J.C.ALCARDE e C.A.F.GRANER, 1967b. Variação na concentração e na quantidade de macronutrientes no fruto do cafeeiro durante o seu desenvolvimento. Anais da Escola Superior de Agricultura "Luiz de Queiroz", Piracicaba, 24:249-263.

CHAPMAN, H.D. e E.R.PARQUER, 1942. Weekly absorption of nitrate by young bearing orange trees growing out-of-door in solution cultures. Plant. Physiology, Lancaster, 17(3):366-376.

CHAPMAN, H.D., 1967. Plant analysis values suggestive of nutrient status of selected crops. In: HARDY, G.W. et alii, ed. Soil testing and plant analysis. Madison, Soil Science Society of America, Inc., v.2, p.77-92.

CHAVERRI, R.G., 1955. Estimaciōn de la variación anual en las hojas del cafeto, de los elementos nutrientes nitrogeno, fosforo, boro, calcio, magnesio por medio del analisis quîmico foliar. San José da Costa Ri $\mathrm{ca}$, Ministērio de Agricultura e Industrias, $16 \mathrm{p}$. (Relatōrio anual do Laboratório de Quĩmica).

CHAVERRI, R.G.; E.BORNEMISZA, S. e F.CHAVES, S., 1957. Resultados del anālisis foliar del cafeto em Costa Rico. San José, Costa Rica. Ministērio de Agricultura e Industrias, 39 p. (Informe técnico, nọ 3).

COELHO, F.A.S. e F.VERLENGIA, 1971. Fertilidade do Solo, Campinas, Instituto Campineiro de Ensino Agrīcola, $384 \mathrm{p}$. 
COLONNA, J.P., 1964. Contribution à l'etude pratique du diagnostic fo liaire du caféier excelsa. Café, Cacao, Thē, Nogent-sur-Marne, 8(4): 264-274.

COOIL, B.J., 1954. Leaf Composition in relation to growth and yield of Coffee in Kona. Kona, Hawai, Coffee Information Exchange, $13 \mathrm{p}$.

CRAFTS, A.S., 1961. Translocation in plants. New York, Holt, Rinechart and Winston, $182 \mathrm{p}$.

CRAFTS, A.S. e C.E.CRISP, 1971. Phloem transport in plants, San Francis co, Freeman, $481 \mathrm{p}$.

DAFERT, F.W., 1895. Sobre as substâncias minerais do cafeeiro. Relatório do Instituto Agronômico de 1888 a 1893, Campinas:183-203.

DROVER, D.P., 1970. A preliminary survey of cocoa nutrition in relation to dieback disease in Papua and New Guinea. Experimental Agriculture, London, $\underline{6}: 33-40$.

EPSTEIN, E., 1975. Nutrição Mineral das Plantas: princípios e perspecti vas. Trad. E.Malavolta, São Paulo, Ed. USP, 341 p.

ESPINOSA, F.M., 1960. El anālisis foliar en el diagnostico del estado nutricional del cafeto. Santa Tecla, El Salvador, Instituto Salvadoreño de Investigaciones del Café, 20 p. (Boletin informativo, supl.2).

ESPINOSA, F.M., 1969. Efecto de diferentes fuentes nitrogeno en la composition foliar y produccion de cafetos jōvenes em um Latossolo argi10so. Agricultura, El Salvador, $\underline{9}(2): 6165$.

FERNANDES, P.D.; G.D.OLIVEIRA; C.RUGGIERO e H.P.HAAG, 1977. Extração de Nutrientes durante o desenvolvimento do fruto do Maracujazeiro amarelo (Passiflora edulis f. flavicarpa Deg.). Anais da Escola Superior de Agricultura "Luiz de Queiroz", Piracicaba, 34:127-137. 
FORESTIER, J. e J.BELEY, 1969. Variabilité de la nutrition minerale et de la production des clones de caféier robusta. Café, Cacao, Thé, Nogent-sur-Marne, 13(4):290-296.

GALLO, J.R.; R.HIROCE; F.A.S.COELHO e S.V.TOLEDO, 1967. Levantamento do Estado Nutricional de cafezais de São Paulo, pela anālise foliar. I. Solo Massapê - Salmourão. Bragantia, Campinas, 26:103-108.

GODOY-JUNIOR, C. e E.A.GRANER, 1970. Adubação do Café. XI. Produção, ren dimento e características do fruto e do grão no quinto ano de colheita. Revista de Agricultura, Piracicaba, 45(1):103-108.

GOPAL, N.H.; N.VASUDEVA e A.BALASU BRABANIAN, 1976. Studies on absorption and translocation of phosphorus using radioactive superphosphate $\left(P^{32}\right)$ in coffee plants. Journal of Coffee Research. Ballchonnur, $\underline{6}(3 / 4)$ : 69-75.

HAAG, H.P. e J.R.SARRUGE, 1967. Uptake of zinc by detached root of young coffee trees (Coffea arabica L., variety Mundo Novo). Fertilitē, Paris, 29: 13-22.

HART, G., 1966. Coffee nutrition. II. Plantation survey. Papua and New, Guinea Agricultural Journal, Port Moresby, 18:62-68.

HIROCE, R.; O.C.BATAGLIA,; J.R.GALLO e F.R.P.de MORAES, 1972. Teores de Nitrogênio nas folhas de cafeeiro, em relação à adubação química. II. Solo Podzólico Vermelho Amarelo orto. Ciēncia e Cultura. Resumos da 24 Reunião Anual da SBPC. São Paulo, 24(7):412-413. Suplemento.

HIROCE, R., 1981. Diagnose foliar em cafeeiro. In: INSTITUTO BRASILEIRO DA POTASSA, ed. Cultura e adubação do cafeeiro. São Paulo, p.117-137.

HOAGLAND, D.R. e A.R.DAVIS, 1923. The composition of the cell sap of the plant in relation to the absorption of ions. Journal of General Physiology, Baltimore, 5:629-646. 
HOAGLAND, D.R., 1937. Some aspects of the salt nutrition of higher plants. Botanical Review, Lancaster, 3:307-334.

HORBERGER, R., 1882. Chemische untersuchunger uber das wachstum der maispflanze. Land wirtschaftliche Jahrbucher, Berlin, 11:359-523.

HUERTA, S.A., 1963. Par de hojas representativo del estado nutritional del cafeto. Cenicafé, Chinchina, 14:111-128.

HUERTA, S.A., 1965. Composição mineral das folhas, adubação e produção do café. Fertilité, Paris, 23:42-52.

KOLLER, O.C., 1975. Influência do virus da tristeza dos citros sobre a absorção e translocação do zinco. Piracicaba, ESALQ/USP, 141 p. (Tese de doutoramento).

KOSS, J.; J.F.CARVAJAL e J.A.SOLANO, 1973. Copper nutrition of Coffee in Costa Rica. Turrialba, 23(2):208-215.

KUMAR, D., 1979. Some aspects of plant-water-nutrient relationships in Coffea arabica L. Kenya Coffee, Nairobi, 44(517):15-21.

LAGATU, H. e L.MAUME, 1926. Diagnostic de l'alimentation d'un vegetal par l'évaluation chimique d'une feuille convenablement choisée. Comples Rendus de l'Academie de Sciences de France. Paris, 182:653-655.

LAGATU, H. e L.MAUME, 1930. Le diagnostic foliar de la pomme de terre. Premier Mémoire. Annales de l'Ecole Nationale Agricole, Montpellier, 20:219-281.

LIEBSCHER, G., 1887. Der Verlauf des Nährstoffanfnahme und seive Bedeutung für die Düngerlehre. Jahrbuch des Landwirtschaffliche, Berlin, 35:335-518. 
LOTT, W.L.; J.P.NERY; J.R.GALLO e J.C.MEDCALF, 1956. A técnica de anālise foliar aplicada ao cafeeiro. Campinas, Instituto Agronōmico, $29 \mathrm{p}$. (Boletim n. 79).

LOUE, A., 1951. Etude de la nutrition du caféier par la méthode du diagnostic foliaire. Bulletin du Centre de Recherches Agronomiques, Bingerville, Ivory Coast, (3):10-25.

LOUE, A., 1957. Studies on the inorganic nutrition of the coffee tree in the Ivory Coast. Berne, International Potash Institute, $68 \mathrm{p}$.

LOUE, A., 1958. A nutrição mineral e a fertilização do café robusta na Costa do Marfin. Fertilité, Paris, $\underline{5}: 27-60$.

MACY, P., 1936. The quantitative mineral nutrient requirements of plants. Plant Physiology, Lancaster, 11:749-764.

MALAVOLTA, E.; F.P.GOMES e T.COURY, 1958. Estudos sobre a alimentação mi neral do cafeeiro (Cobfea arabica L. variedade Bourbon Vermelho). I. Resultados preliminares. Piracicaba, ESALQ/USP, 16 p. (Boletim no 14).

MALAVOLTA, E.; L.N.MENARD e W.L.LOTT, 1959. Estudos sobre a alimentação mineral do cafeeiro. II. Absorção do Superfosfato radiativo pelo cafeeiro (Coffea arabica L. var. Bourbon Amarelo) em condições de campo. Bragantia, Campinas, 16:101-111.

MALAVOLTA, E.; E.A.GRANER; J.R.SARRUGE e L.GOMES, 1963. Estudos sobre a alimentação mineral do cafeeiro. XI. Extração de macro e micronutrien tes, na colheita, pelas variedades "Bourbon Amarelo", "Caturra Amare10" e "Mundo Novo". Turrialba, 13(3):188-189.

MALAVOLTA, E.; E.A.GRANER; H.P.HAAG e J.R.SARRUGE, 1964. Estudos sobre a nutrição mineral do café. XII. Efeito da adubação na composição mineral das folhas. Anais da Escola Superior de Agricultura "Luiz de. Queiroz", Piracicaba, 21:74-78. 
MALAVOLTA, E.; H.P.HAAG; F.A.F.MELLO e M.0.C.BRASIL SOBRo., 1967. Os nutrientes essenciais. In: MALAVOLTA, E. et alii, Nutrição mineral de algumas culturas tropicais. São Paulo, Ed. da Universidade de São Pau 10, p.1-39.

MALAVOLTA, E., 1974. Nutrição mineral do cafeeiro. In: Simpósio sobre café, IBC/IAPAR/AEAP, Londrina, p. 1-36.

MALAVOLTA, E., 1979. Nutrição mineral e adubação do citros. Boletim Técnico do Instituto da Potassa. Piracicaba (5):13-71.

MALAVOLTA, E., 1981. Nutrição Mineral e adubação do cafeeiro, passado, presente e perspectivas. In: INSTITUTO BRASILEIRO DA POTASSA, ed. Nutrição e adubação do cafeeiro. São Paulo, p.138-178.

MASCARENHAS, H.A.A., 1972. Acūmulo de matēria seca, absorção e distribuição de elementos na soja, durante o seu ciclo vegetativo. Piracicaba, ESALQ/USP, 100 p. (Tese de Doutoramento).

MATHEW, P.K. e W.K. RAO, 1980. Nutritional requirements of coffee. Planters' chronicle, Coimbatore, 75(10):437-441.

MAXIMOV, N.A., 1946. Fisiologia vegetal. Versiōn española por Armando Teodoro Hunziker. Buenos Aires, ACME, $433 \mathrm{p}$.

McILRATH, W.J., 1965. Mobility of boron in several dicotyledonous species. Botanical gazette, Chicago, 126:27-30.

MEDCALF, J.C.; W.L.LOTT; P.B.TEETER e L.R.QUINN, 1955. Programa experimental no Brasil. Boletim do IBEC Research Institute, São Paulo (6): $1-75$.

MEDINA, H.P. e F.GROHMANN, 1962. Contribuição ao estudo de anālise granu lométrica do solo. In: Anais do 60 Congresso Brasileiro de Ciēncia do Solo, Salvador, p. 29-38. 
MENARD, L.N., 1956. Efeitos do fósforo e de alguns micronutrientes no crescimento e composição química do cafeeiro (Coffea arabica L., var. Caturra, K.M.C.) cultivado em solução nutritiva. Piracicaba, ESALQ/ USP, 64 p. (Tese de Doutoramento).

MENARD, L.N. e E.MALAVOLTA, 1957. Absorção e distribuição do fósforo radioativo no cafeeiro (Coffea arabica L. var. Caturra, K.M.C.). Boletim da Superintendência dos Serviços do Café, São Paulo, 32(366):7-14.

MILTHORPE, F.L. e J.MOORBY, 1969. Vascular transport and its Significance in plant growth. Annual Review of Plant Physiology. Stanford, 20: 117-138.

MIRANDA, A., s.d. Relación entre el nitrogeno y el potasio con el contenido foliar de cafeina en Coffea arabica, var. Caturra K.N.C. Panamá, Departamento de Café y Cacao del MIDA, p. 116-133.

MITCHELL, J.W.; I.R.SCHNEIDER e H.G.GAUCH, 1960. Translocation of particles within plants. Science, New York, 131(3417):1863-1870.

MORAES, F.R.P.de e R.A.CATANI, 1964. A absorção de elementos minerais pe 10 fruto do cafeeiro durante sua formação. Bragantia, Campinas, 23 (26):331-336.

MÚLLER, L., 1959. La aplicación del diagnostico foliar en el Cafeto (Coffea arabica L.) para una mejor fertilization. Turrialba, $9(4)$ : $110-122$.

MUNSON, R.D. e W.L. NELSON, 1973. Principles and practices in plant analysis. In: WALSH, L.M. \& J.D.BEATON, ed. Soil testing and plant, analysis. Madison, Wis., Soil Science Society of America, p.223-248.

NJAGI, S.B.C., 1980. Economics of fertilizer use in the production of Coffee. I. Nitrogen fertilizers. Kenya Coffee, Nairobi, 45(526):15-20. 
NORMAN, A.G., 1944. Inoculation and nitrogen nutrition of soybeans. Soybean Digest, Hudson, $4(11): 41-42$.

OMATOSO, T.I. e A.OLOJOLA, 1972. The effects of macronutrientes on the growth and leaf composition of Coffea canephora Pierre. Turrialba, $\underline{22}(1): 53-60$.

ORUKO, B.A. e G.M.GATITU, 1979. The role of potassium and magnesium in the nutrition and yield of Coffea arabica L. Kenya Coffee, Nairobi, $44(515) 15-24$.

OYEBADE, T., 1976. Studies on the pathern of growth and development of Cobfea canephora fruit in Nigéria. Turrialba, 26(3):257-260.

PARRA, H.J.; A.McCORMICKN e F.ARCILA 0., 1962. Sitios optimos para fertilizar el café. Cenicafé, Chinchina, 13:115-124.

PEREIRA, J.F.; A.S.CRAFTS e S.YAMAGUCHI, 1963. Translocation in coffee plants. Turrialba, 13(2):64-79.

PEREIRA, J.F. e S.YAMAGUCHI, 1964. Absorption and translocation of arsenate arsenic by Coffee plants. Turrialba, 14:91-93.

RAJU, L. e T.R.SUBRA MANIAN, 1969. Studies on leaf analysis in the NPK nutrition of arabica Coffee. Turrialba, 19(1):49-56.

RAMAIAH, P.K. e N.VASUDEVA, 1969. Observations on the growth of Coffee berries in South India. Turrialba, 19(4):455-464.

ROBERTSON, R.N., 1951. Mechanism of absorption and transport of inorganic nutrients in plants. Annual Review of Plant Physiology, Stanford, 2: $1-24$. 
ROY, W. e F.E.GARDNER, 1946. Seasonal absorption of nutrient ions by orange trees in sand culture. Proccedings American Society of Horticultural Science, College Park, 47:107-118.

RUSSEL, E.J., 1927. Soil conditions and plant growth, London, Longmans, Green and Co, $655 \mathrm{p}$.

SAMUELS, G. e B.G.CAPO, 1952. Effects of level of a fertilizer element on the uptake and concentration of that element and other elements in a plant. Agronomy Journal, Washington, 44(7):352-357.

SAMUELS, G., 1957. Abonos para café. Revista de Agricultura de Puerto Rico, San José, $44(2): 121-125$.

SARRUGE, J.R.; L.GOMES; H.P.HAAG e E.MALAVOLTA, 1963. Estudo sobre a alị mentação mineral do algodoeiro. I. Marcha da absorção dos macronutrien tes (Nota prévia). Anais da Escola Superior de Agricultura "Luiz de. Queiroz", Piracicaba, 20: 13-30

SARRUGE, J.R.; H.V.de AMORIN e E.MALAVOLTA, 1966. Estudos sobre a alimentação mineral do cafeeiro. XVIII. Nota sobre a absorção foliar e radicular do fósforo por plantas jovens de Coffea arabica L., var.Mundo Novo. Anais da Escola Superior de Agricultura "Luiz de Queiroz",Pi racicaba, 23:81-84

SARRUGE, J.R. \& H.P.HAAG, 1974. Anālises quĩmicas em plantas. Piracicaba, Departamento de Quĩmica, E.S.A. "Luiz de Queiroz"/USP, 56 p.

SHEAR, C.B. e C.B.SMITH, 1969. Differential accumulation of mineral elements in the leaves of seedling progenies of sevem apple cultivars. Journal of the American Society Horticultural Science, College Park, 94:471-473.

SILVA, H.L. e H.L.SILVA, 1956. Variação de composição mineral de folhas de cafeeiro. Revista do Café Portugues, Lisboa, 12:15-34. 
SILVA, H.L. e H.L.SILVA, 1957. Variação de composição mineral de folhas de Cafeeiro. Revista do Café Portugues, Lisboa, 14:24-60.

SILVA e SOUZA, V.H.da; M.MAESTRI; J.M.BRAGA e J.R.P.CHAVES, 1975. Variações no teor de alguns elementos minerais nas folhas e frutos de café (Cofbea arabica L. var. "Mundo Novo"). Revista Ceres, Viçosa 22(123): 310-331.

SNYDER, H., 1893. The effect of the wheat plant upon the soil in different stages of its growth. Bulletin of the Minnesota Agricultural Experiment Station, St.Paul (29):153-160.

SOLORZANO, V.N. e V.E.BORNEMISZA, 1976. Estudios del cultivo de yuca en Costa Rica. II. Composiciōn quimica y producción de tres cultivares. Turrialba, 26(3):261-267.

STEENBJERG, F., 1951. Yield curves and chemical plant analysis. Plant \& Soil, Gravenhage, 3:97-109.

STEENBJERG, F. e S.T.JAKOBSEN, 1963. Plant and yield curves, Soil Science, New Brunswick, 95:69-88.

STEPHENS, D., 1967. A note on the correlations between coffee yields an soil analysis in Uganda. East African Agricultural and Forestry Journal, Nairobi, 32:456-458.

STEUCEK, G.L. e H.V.KOONTZ, 1970. Phloem mobility of magnesium. Plant, Physiology, Lancaster, 46:50-52.

TAKIDZE, R.M., 1981. Determination of mineral nutrient requirements of citrus crops by means of foliar diagnosis. Subtropicheskie Kul'tury, (1):61-68. 
TESHA, A.J. e D.KUMAR, 1979. Effects of soil moisture potassium and nitrogen on mineral absorption and growth of Coffea arabica. Turrialba, $29(3): 213-218$.

VAN RAIJ, J.C. e M.A.T.ZULHO, 1977. Métodos de anālise de solo. Campinas, Instituto Agronōmico de Campinas, 16 p. (Circular nọ 63).

VASUDEVA, N. e N.H.GOPAL, 1977. Distribution of nitrogen in ripe fruits of coffee plants. Indian Coffee, Chickmagalus, 41 (4):121-123.

VERLIERE, G.,1973a. La nutrition minērale et la fertilisation du caféier sur sol schisteux en Cóte D'ivoire. IV. Influence de la fertilisation minérale sur la composition du fruit. Café, Cacao, Thē, Nogent-surMarne, 17(4):269-280.

VERLIERE, G., 1973b. La nutrition minērale et la fertilisation du caféier sur sol schisteux en Côte D'ivoire. I. Étude de la nutrition minérale. Café, Cacao, Thē, Nogent-sur-Marne, 17(2):97-124.

VERLIERE, G., 1973c. La nutrition minérale et la fertilisation du caféier sur sol schisteux en Côte D'ivoire. III, Relation entre les rendements et la composition minērale des feuilles. Café, Cacao, Thē, Nogent-surMarne, 17(3):211-222.

WALQUER, T.W., 1960. Uptake of ions by plants growing in soil. Soil Science, New Brunswick, 89:328-332.

WITHNER, C.L., 1949. Movement of $\mathrm{P}^{32}$ in maturing corn Plants. Plant Physiology, Lancaster, 24:527-529.

ZEIGER, D.C. e J.E.SHELTON, 1969. Seasonal distribution of Manganese in leaves and Shoots of Red Delicious apple tress showing internerval bark necrosis (IBN). Hort.Science, Saint Joseph, 4:213-215. 